Universidade de Brasília - UnB

Faculdade de Economia, Administração, Contabilidade, Ciência da Informação e Documentação - FACE

Departamento de Ciência da Informação e Documentação - CID

Cristiane de Castro Pires

Dienner Mory Rodrigues Silva

\title{
A biblioteca e a biblioterapia no tratamento dos pacientes da Associação Brasileira de Assistência as Pessoas com Câncer - ABRAPEC
}


Universidade de Brasília - UnB

Faculdade de Economia, Administração, Contabilidade, Ciência da Informação e Documentação - FACE

Departamento de Ciência da Informação e Documentação - CID

Cristiane de Castro Pires

Dienner Mory Rodrigues Silva

\section{A biblioteca e a biblioterapia no tratamento dos pacientes da Associação Brasileira de Assistência as Pessoas com Câncer - ABRAPEC}

Monografia apresentada ao Departamento de Ciência da Informação e Documentação como requisito parcial para obtenção do grau de bacharel em Biblioteconomia.

Orientadora:

Profa. Drª. Maria Alice Guimarães Borges 
P667b Pires, Cristiane de Castro.

A biblioteca e a biblioterapia no tratamento dos pacientes da Associação Brasileira de Assistência as Pessoas com Câncer ABRAPEC / Cristiane de Castro Pires, Dienner Mory Rodrigues da Silva. - Brasília: UnB, 2009.

$111 \mathrm{f}$. : il., color.

Monografia (graduação) - Universidade de Brasília, Departamento de Ciência da Informação e Documentação, Brasília, 2009.

Orientadora: Prof $\stackrel{\text { a }}{\text {. Dr }}$. Maria Alice Guimarães Borges.

1. Biblioterapia. 2. Planejamento de Biblioteca. 3. Tratamento de Câncer. 4. Biblioteca Especial. 5. ONG ABRAPEC. I. SILVA, Dienner Mory Rodrigues da. 
A Deus, por tudo.

Aos meus pais, pelo amor e dedicação.

A minha querida irmã Lili, minha amiga de todas as horas. A toda minha família, pela compreensão e carinho de sempre. Aos meus amigos, pela torcida. Aos pacientes da ABRAPEC, motivação desse trabalho.

Cristiane Castro

Dedico este trabalho a todas as pessoas portadoras de câncer e em especial a meu irmão Daniel, que acometido pela doença, graças a Deus se curou.

Dienner Mory 


\section{Agradecimentos}

À Deus, primeiramente, que me deu perseverança e força para seguir em frente. À minha orientadora, professora Maria Alice, por sua paciência, dedicação e apoio. Aos meus pais e minha irmã, que estiveram ao meu lado quando precisei. A todos os professores deste curso, que me nutriram com seus conhecimentos e amizade. À Sandra, Assistente social da ABRAPEC, por sua colaboração.

Enfim, a todos que contribuíram de forma direta ou indireta para realização desta monografia. A todos vocês o meu muito obrigada!

\section{Cristiane Castro}

Meus sinceros agradecimentos a todos aqueles que de alguma forma doaram um pouco de si para que a conclusão deste trabalho se tornasse possível. Agradeço aos meus pais, Teobaldo e Marta pela dedicação, compreensão e apoio dados ao longo desta jornada. Aos meus colegas de curso que me acompanharam durante esses quatro longos anos. À

Sandra, Assistente Social da ABRAPEC que deu total apoio à realização deste projeto e em especial

à professora Maria Alice Guimarães Borges, paciente orientadora e organizadora dos meus pensamentos desconexos. 
"Livros são os mais silenciosos e constantes amigos; os mais acessíveis e sábios conselheiros; e os mais pacientes professores."

Charles W. Elliot. 


\section{Resumo}

Esta monografia analisa a biblioterapia, o processo de planejamento e as peculiaridades existentes entre os diversos tipos de bibliotecas a partir de conceitos, objetivos e discussões. Apresenta um estudo de caso na Associação Brasileira de Assistência as Pessoas com Câncer - ABRAPEC, unidade de Taguatinga/DF, que permite a compreensão de seu funcionamento e da sua realidade atual do ponto de vista de seus objetivos e atividades. Estabelece o perfil dos pacientes e funcionários desta instituição, ambos traçados por meio de uma pesquisa descritiva, na qual verificou-se o interesse dos usuários pela reestruturação desta unidade de informação. O levantamento destes dados forneceu subsídios para a elaboração de um projeto de reestruturação da biblioteca. Este projeto visa a atender as necessidades informacionais dos pacientes, seus familiares e funcionários, incentivar a leitura e oferecer atividades biblioterapêuticas que possam melhorar a sua qualidade de vida e o seu bem-estar.

Palavras-chave: Biblioterapia; Planejamento de biblioteca; Tratamento do câncer; Biblioteca especial; ONG ABRAPEC. 


\begin{abstract}
This monograph analyzes the bibliotherapy, the planning process and the peculiarities between the different types of libraries from concepts, objectives and discussions. It presents a case study in the Brazilian Association of Assistance for People with Cancer - ABRAPEC, Taguatinga-DF unit in Brazil, which gives an understanding of its operation and its current reality concerning its objectives and activities. It establishes the profile of patients and its staff, both drawn by means of a descriptive study, in which was shown the interest of users for the restructuring of this unit of information. The survey of these data provided support for the preparation of a project to restructure the library. This project aims to meet the informative needs of patients, their families and staff, encourage reading and offer book therapy activities that can improve their quality of life and well-being.
\end{abstract}

Keywords: Bibliotherapy; Planning Library; treatment of cancer; special libraries; ABRAPEC NGOs. 


\section{Lista de Quadros}

Quadro 1 - Conceitos e Objetivos da Biblioterapia. .20

Quadro 2 - Definições de Biblioterapia que apresentam como núcleo os processos terapêuticos. .22

Quadro 3 - Definições de Biblioterapia que apresentam como núcleo os processos

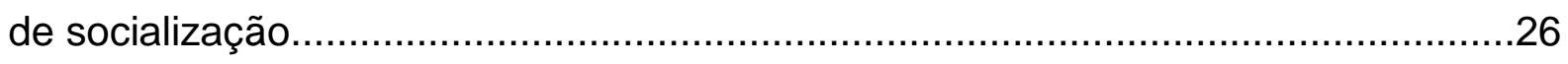

Quadro 4 - Definições de Biblioterapia que apresentam como núcleo os procedimentos de agentes da Biblioterapia.....................................................27

Quadro 5 - Definições de Biblioterapia que apresentam como núcleo as Relações estabelecidas com o livro. .28

Quadro 6 - Características dos três tipos de biblioterapia. 33 


\section{Lista de llustrações}

Figura 1 - Diagrama sistêmico da ABRAPEC /DF .............................................5

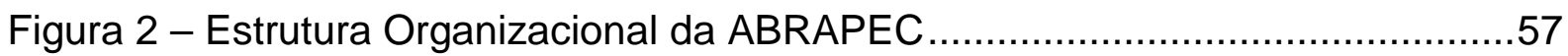

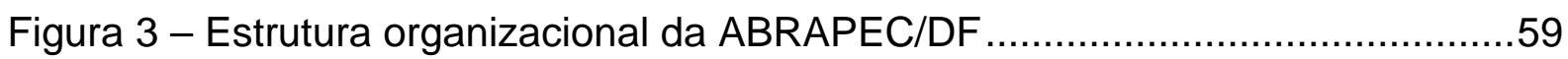

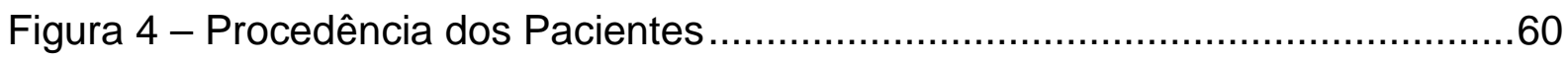

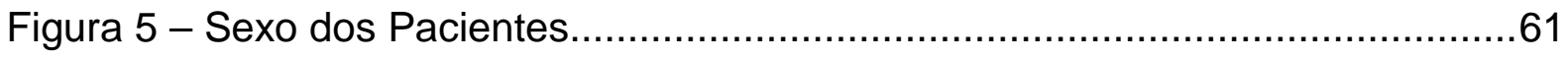

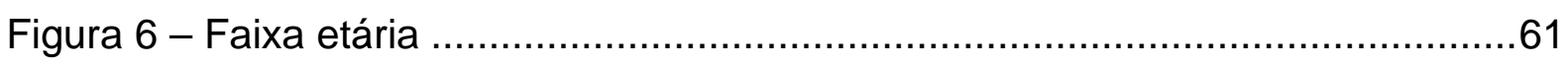

Figura 7 - Tipos de Câncer .........................................................................62

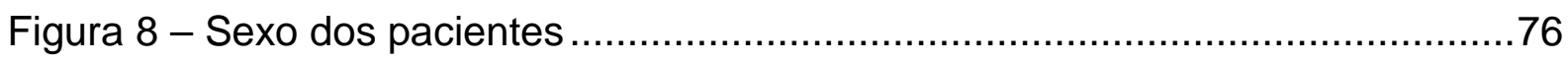

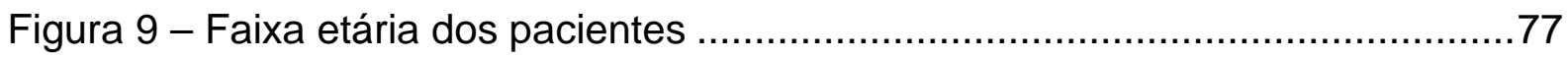

Figura 10 - Tempo que os pacientes freqüentam a ABRAPEC ............................77

Figura 11 - Freqüência com que os usuários vão a ABRAPEC ……………….....78

Figura 12 - Nível de Instrução dos Pacientes da ABRAPEC ...................................78

Figura 13 - Gosto pela leitura dos pacientes da ABRAPEC ..................................79

Figura 14 - Freqüência de Leitura dos pacientes da ABRAPEC ……………........79

Figura 15 - Assuntos que os pacientes da ABRAPEC gostam ou costumam Ler ....80

Figura 16 - Opinião sobre a criação de uma Biblioteca na ABRAPEC ......................80

Figura 17 - Quantidade de pacientes que utilizam os livros da ABRAPEC ...............81

Figura 18 - Quantidade de pacientes que consideram importante a Biblioteca da ABRAPEC possuir revistas e jornais.

Figura 19 - Assuntos que os pacientes consideram importante ter na Biblioteca da

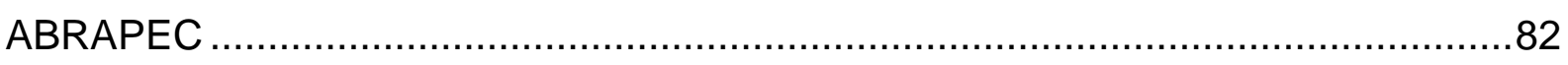

Figura 20 - Benefícios que os pacientes consideram que a leitura proporciona ......83

Figura 21 - Serviços que os pacientes da ABRAPEC buscam numa biblioteca .......83

Figura 22 - Faixa etária das funcionárias e voluntárias da ABRAPEC .....................85

Figura 23 - Nível de Instrução das Funcionárias e Voluntárias da ABRAPEC .........85

Figura 24 - Utilização dos livros da ABRAPEC pelos funcionários e voluntários ......86

Figura 25 - Assuntos considerados importantes ter na Biblioteca da ABRAPEC pelos

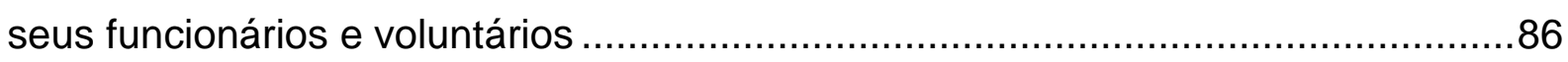

Figura 26 - Finalidade na utilização da Biblioteca da ABRAPEC ..........................87

Figura 27 - Serviços que os funcionários e voluntários consideram importante a Biblioteca da ABRAPEC oferecer. 
Figura 28 - Benefícios que os funcionários e voluntários da ABRAPEC consideram

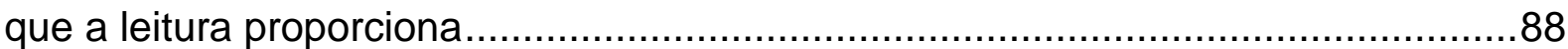




\section{Lista de Fotos}

Foto 1 - Fachada da ABRAPEC/DF .......................................................64

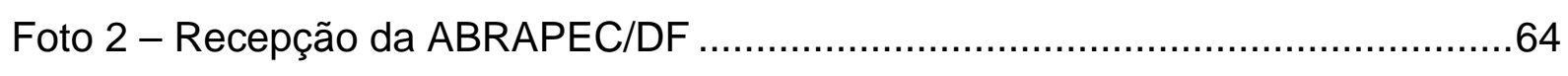

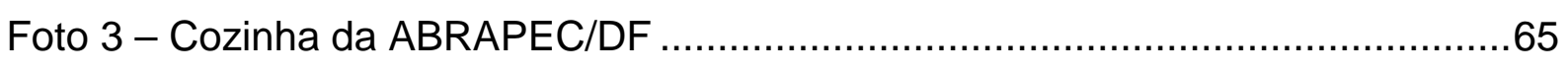

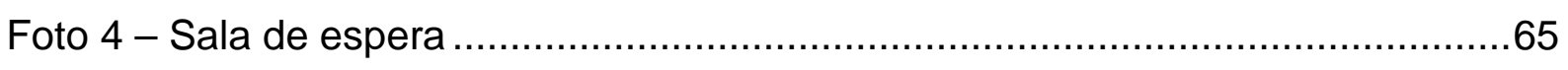

Foto 5 - Sala onde se realiza o atendimento com Assistente Social .....................67

Foto 6 - Sala onde é realizado o atendimento psicológico .................................67

Foto 7 - Sala onde são armazenados os mantimentos recebidos pela instituição e outros objetos frutos de doação .............................................................68

Foto 8 - "Sala" onde os pacientes são recebidos diariamente e onde ocorrem as

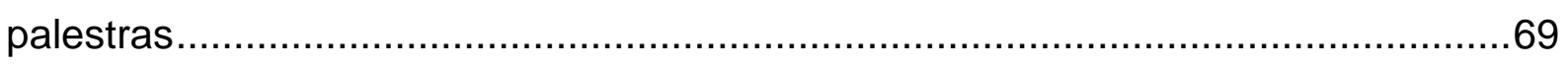

Foto 9 - Palestra sobre Prevenção Gripe Influenza H1N1 ..................................69

Foto 10 - Sala onde é realizada a Massagem terapêutica ...................................72

Foto 11 - "Sala" onde os alunos do EJA tem as aulas......................................72

Foto 12 - Maquinas de costura utilizadas na oficina de costura ...........................73

Foto 13 - Festa junina............................................................................ 73

Foto 14 - Comemoração dia das mães.......................................................73

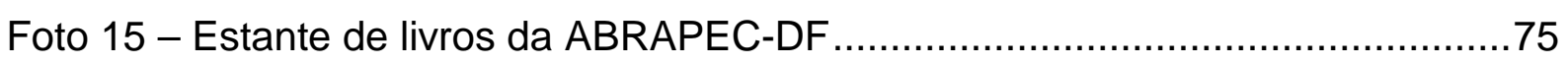




\section{SUMÁRIO}

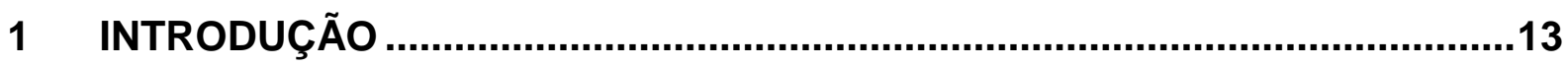

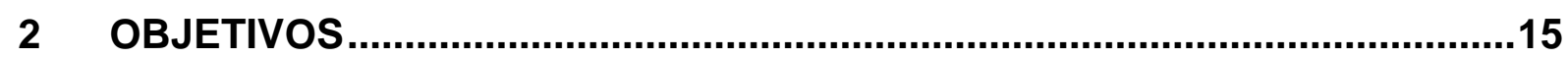

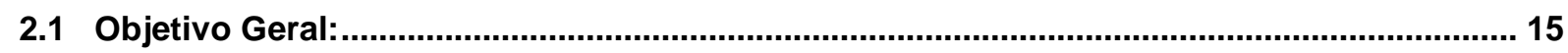

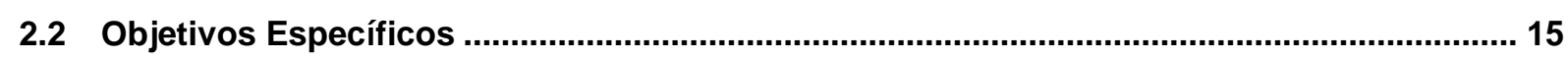

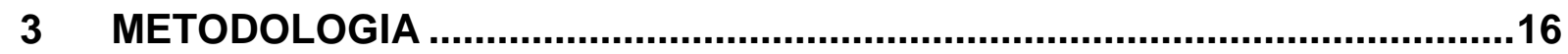

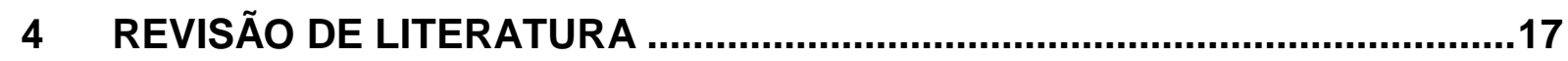

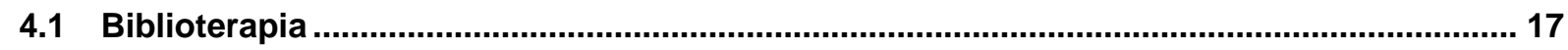

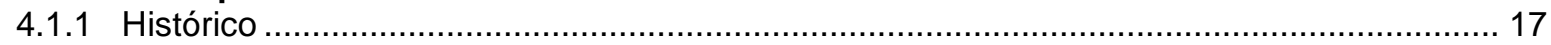

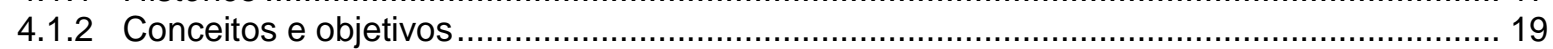

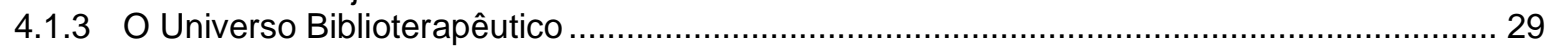

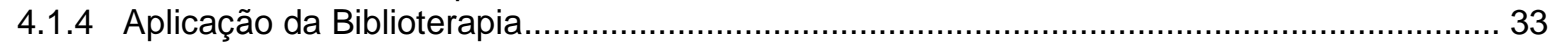

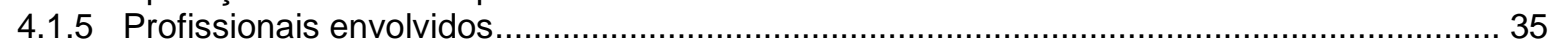

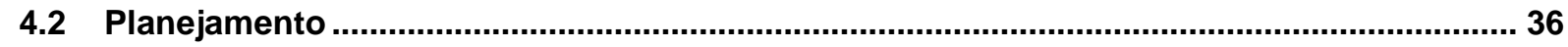

4.2.1 Novos paradigmas da Sociedade da Informação e do Conhecimento ................................ 36

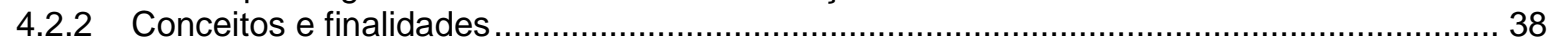

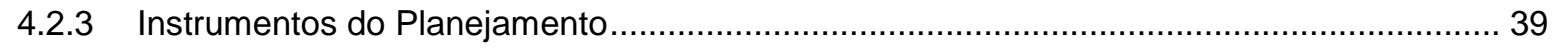

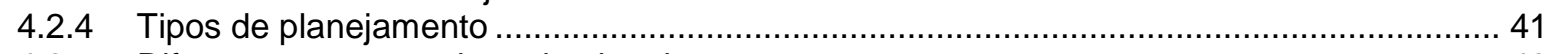

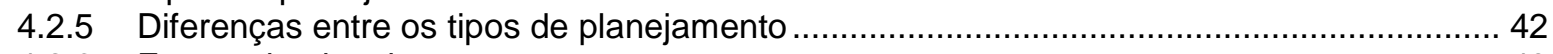

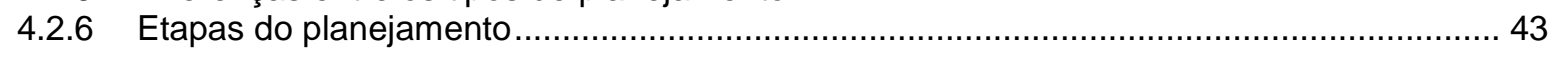

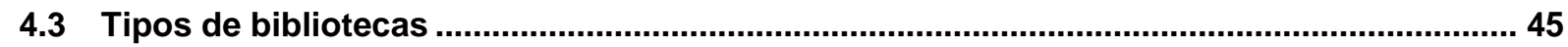

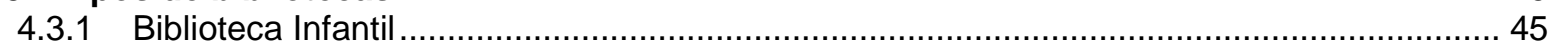

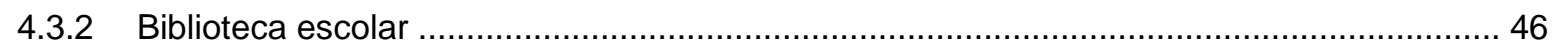

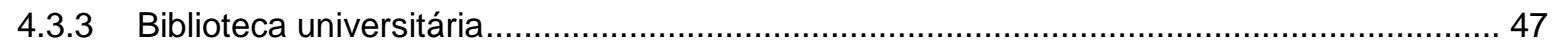

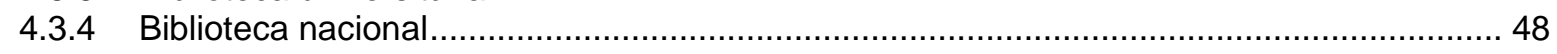

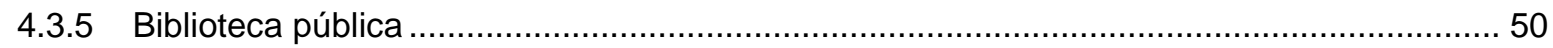

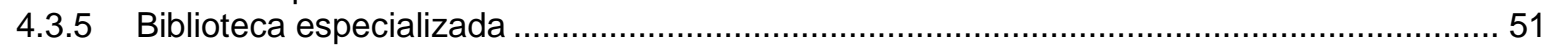

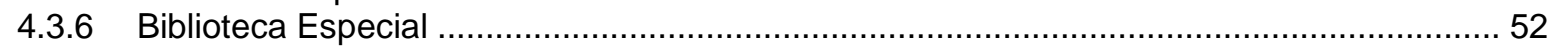

5 ESTUDO DE CASO: ASSOCIAÇÃO BRASILEIRA DE ASSISTÊNCIA AS PESSOAS COM CÂNCER - ABRAPEC ..........................................................54

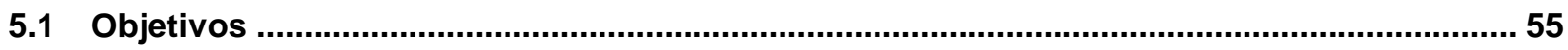

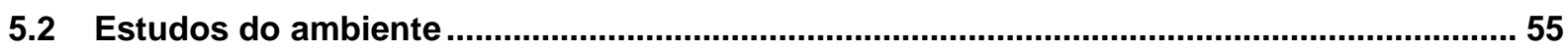

5.2.1 Associação Brasileira de Assistência as Pessoas com Câncer - ABRAPEC ....................56

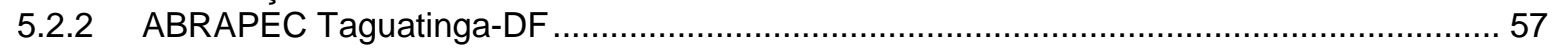

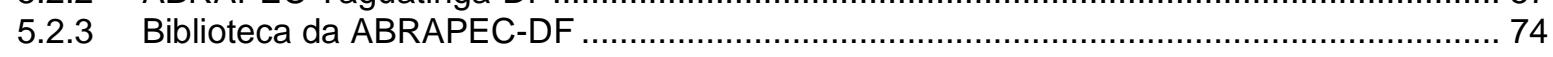

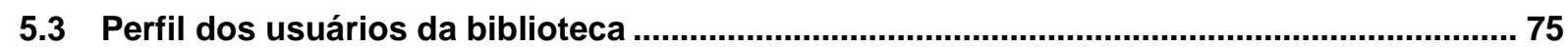

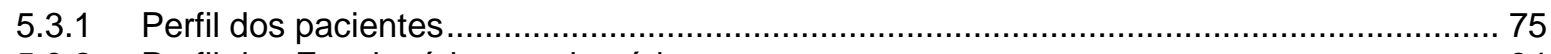

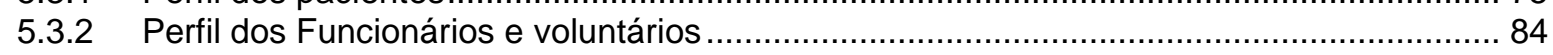


6 PROJETO DE REESTRUTURAÇÃo dA BIBLIOTECA DA ABRAPEC- DF..90

6.1 Introdução ........................................................................................................................ 90

6.2 Objetivos:

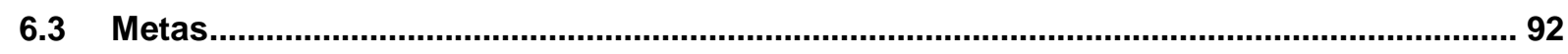

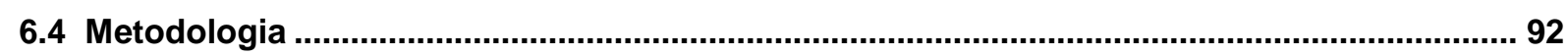

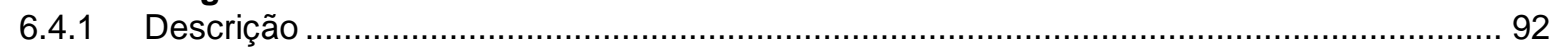

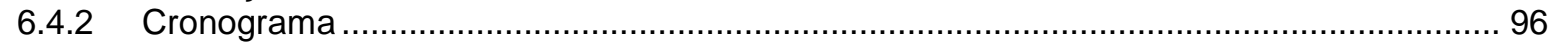

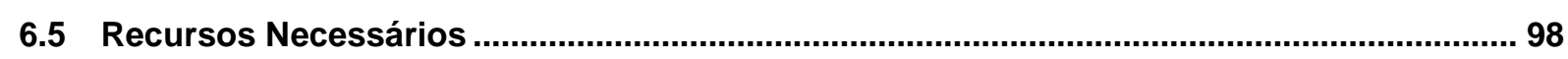

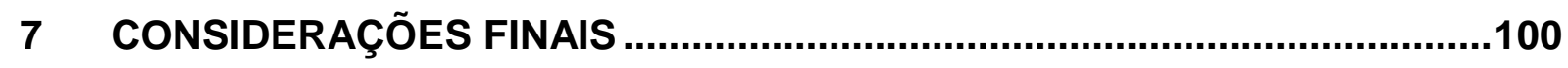

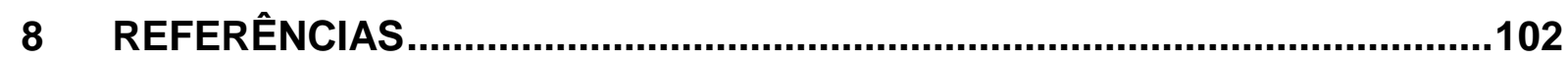

ANEXOS:

ANEXO A - QUESTIONÁRIO APLICADO AOS PACIENTES DA ABRAPEC.......107 ANEXO B - QUESTIONÁRIO APLICADO AOS FUNCIONÁRIOS DA ABRAPEC110 


\section{Introdução}

O aumento crescente do número de casos de câncer é visível no Brasil e no mundo. Além dos problemas fisiológicos que ele pode acarretar, abala psicologicamente os doentes, tornando-os vulneráveis e fragilizados. O tratamento geralmente marca um caminho longo, incerto e doloroso, fazendo com que muitos pacientes fiquem inseguros, revoltados, deprimidos, ansiosos. A família dos enfermos também vivencia essa dor, essa angustia, e muitas vezes se sentem impotentes diante da situação vivenciada. Paralelamente aos tratamentos de quimioterapia e radioterapia, percebe-se a necessidade e importância de ser feito um acompanhamento psicológico, para que o tratamento se torne menos doloroso. No entanto, nem todos possuem condições financeiras de arcar com as despesas do tratamento psicológico, e o atendimento público se mostra caótico.

Tendo em vista as necessidades apresentadas pelos pacientes e por seus familiares e, com o intuito de diminuir o desgaste emocional de pessoas que possuem algum tipo de câncer e que se encontram em estágio de vulnerabilidade social, surgiu a Associação Brasileira de Assistência as Pessoas com Câncer ABRAPEC, que é uma organização não-governamental que atende gratuitamente pessoas portadoras de câncer. É uma Instituição que tem como principal objetivo melhorar a qualidade de vida dessas pessoas e para isso desenvolve diversas atividades terapêuticas.

Para se obter a base teórica para construção dessa monografia, foi realizada uma revisão de literatura e um estudo de caso. A revisão de literatura versou sobre os seguintes temas: biblioterapia, o processo de planejamento e tipos de biblioteca. A revisão sobre biblioterapia expõe os benefícios da utilização dos livros e da leitura; a revisão de planejamento mostra a importância de se planejar para se elaborar projetos eficientes e eficazes; e a revisão de tipos de biblioteca visa esclarecer as principais diferenças existentes entre as bibliotecas para que se possa compreender com que tipo de biblioteca se está trabalhando, bem como para delimitar suas características, seu público-alvo e suas necessidades informacionais, e propor serviços e produtos adequados.

Notou-se os possíveis benefícios que a aplicação da terapia por meio dos livros poderia proporcionar aos pacientes dessa instituição. Por isso, uma das 
propostas desta monografia é sugerir o desenvolvimento de atividades, como a hora do conto e grupos de leitura, que visem o bem estar dos pacientes dessa ONG por meio da biblioterapia, tendo em vista a sua importância e o seu uso cada vez mais freqüente para a melhoria da qualidade de vida de pessoas enfermas.

Para conhecer a realidade da ABRAPEC, sua missão e seus principais objetivos quanto ao atendimento dos pacientes que freqüentam a unidade regulamente, foi feito um Estudo de Caso composto por um diagnóstico da Instituição e por um Estudo de Usuários, para conhecer o perfil dos usuários dessa ONG e entender suas reais necessidades. Ambos foram realizados com o intuito de que ao propor o projeto, o mesmo se adequasse à realidade e necessidades desta Associação.

Ao final do trabalho são apresentadas as propostas para execução de um projeto de reestruturação da Biblioteca da ABRAPEC-DF, que conta com o desenvolvimento de atividades biblioterapêuticas. 


\section{Objetivos}

\subsection{Objetivo geral:}

Proporcionar acesso à informação e à leitura aos pacientes da ABRAPEC-DF, visando à melhoria da sua qualidade de vida.

\subsection{Objetivos específicos}

- Estudar a função terapêutica da leitura - biblioterapia - e seu auxilio no tratamento de pacientes portadores de câncer.

- Estudar o processo de planejamento e sua importância na elaboração de projetos.

- Caracterizar os aspectos relacionados aos tipos de bibliotecas existentes.

- Compreender o funcionamento da Associação Brasileira de Assistência as Pessoas com Câncer - ABRAPEC.

- Conhecer a realidade atual da ABRAPEC, do ponto de vista de seus objetivos e atividades.

- Conhecer o perfil dos pacientes da ABRAPEC.

- Propor uma intervenção para a melhoria da Biblioteca da ABRAPEC. 


\section{Metodologia}

A metodologia utilizada no desenvolvimento desta monografia consta de três etapas que incluem:

1. Revisão de literatura, a partir de uma pesquisa documental em bibliotecas e na Internet, sobre:

- Biblioterapia;

- O processo de planejamento;

- Tipos de bibliotecas.

2. Estudo de caso sobre a Associação Brasileira de Assistência as Pessoas com Câncer - ABRAPEC, incluindo as seguintes etapas:

- Diagnóstico da instituição;

- Estudo de usuários: pesquisa descritiva com os pacientes e com os funcionários da ABRAPEC-DF, seguindo as etapas de: coleta de dados; processamento e análise dos dados obtidos, visando o estabelecimento do perfil dos usuários.

3. Elaboração do projeto de reestruturação da biblioteca, estabelecendo os objetivos, as normas e padrões de seleção e organização, e as atividades de incentivo a leitura no âmbito da instituição. 


\section{Revisão de Literatura}

\subsection{Biblioterapia}

"A biblioterapia, uma novidade? Nem um pouco! Quanto mais longe remontarmos na História, mais encontraremos esta intuição da virtude terapêutica do livro e da narrativa" (OUAKNIN, 1996, p.27).

Como cita Quaknin (1996), a biblioterapia não é uma prática recente, por meio da literatura é notável sua presença milênios atrás.

\subsubsection{Histórico}

A idéia de leitura como forma terapêutica é antiga: há muitos milênios além de terapêutica era considerada sagrada. De acordo com Montet (1989, p. 306-307), dentro dos templos egípcios, muitas vezes denominados como "casas de vida", eram situadas as bibliotecas. E quando o rei Neferhotep desejava consultar os livros de TUM, os cortesãos diziam: "Que Tua Majestade entre nas bibliotecas e que Tua Majestade possa ver todas as palavras sagradas".

Alves (1982, p. 54-55) complementa essa idéia ao dizer que,

Há milênios atrás, o faraó egípcio Ramsés II mandou colocar no frontispício de sua biblioteca a inscrição: 'Remédios para a alma'. Entre os romanos do primeiro século, nós vamos encontrar em Aulus Cornelius Celsus, palavras de estímulo ao uso da leitura e discussão dos preceitos dos grandes oradores como forma terapêutica.

Além disso, "os gregos fizeram associação de livros como forma de tratamento médico e espiritual, ao conceberem suas bibliotecas como 'a medicina da alma". Outro fato interessante ocorreu no Hospital Al Mansur, em 1272, onde era recomendada leitura de algumas passagens escolhidas do Alcorão para fazer parte do tratamento médico (MARCINKO apud FERREIRA, 2003, p. 36).

Segundo Alves (1982, p. 55), a biblioterapia começou a ser utilizada nos Estados Unidos em torno de 1800. Benjamim Rush foi considerado um dos precursores americanos por ter aconselhado a leitura para doentes mentais. 
Recomendou em seu livro "Medical inquiries and observations upon the diseases of the mind", o emprego da leitura como auxilio à psicoterapia, tanto para os doentes mentais como para as pessoas que possuíam "conflitos internos, melancolia, medos, manias ou, mesmo, para idosos."

Apesar de sua prática ser antiga, a biblioterapia só se tornou definitivamente um campo de pesquisa a partir da década de 30, quando Emma T. Foremam "insistiu para que a biblioterapia fosse vista e estudada como uma ciência e não como arte" (ORSINI apud FERREIRA, 2003, p.37).

Na década de 40, houve um aumento na publicação de artigos sobre o tema, surgindo em 1949 o primeiro Ph.D., Caroline Shrodes, em biblioterapia (FERREIRA, 2003).

Seitz (2005, p. 92) ajuda prosseguir pela evolução da biblioterapia quando faz uma análise dos acontecimentos nessa área nos anos 70, 80 e 90:

\begin{abstract}
$\mathrm{Na}$ década de setenta, muitos avanços foram alcançados no sentido de proporcionar uma base muito ampla para o desenvolvimento da biblioterapia como um campo a ser explorado por médicos, psicólogos, bibliotecários, educadores e outros profissionais que se engajavam na busca de registrar os benefícios da mesma, quando aplicada a diferentes tipos de clientela. Já, as décadas de oitenta e noventa representaram um aprofundamento das questões teóricas até então consideradas discutíveis, surgindo a identificação de novos métodos e uma constante necessidade de pesquisas para assegurar cada vez mais suas aplicações e o delineamento de nova tendência.
\end{abstract}

Silva (2005, p.66-67), após estudo das características da produção documental sobre biblioterapia no Brasil, constata que a partir do ano de 2000 ocorre um aumento nessa produção e "que a sua produção é na sua grande maioria uma iniciativa de pesquisadores "isolados" cujo interesse acerca de Biblioterapia data de alguns anos ou até mesmo décadas." E complementa que "essa produção está situada, notadamente, em núcleos de pesquisa dentro de instituições de ensino superior, particularmente as Universidades Federais".

Ferreira considera que hoje "a Biblioterapia é um campo de produção científica e de atuação profissional que envolve médicos, psicólogos, educadores, bibliotecários, assistentes sociais, psiquiatras e terapeutas de diversas correntes" (FERREIRA, 2003, p. 37). 


\subsubsection{Conceitos e objetivos}

Conceituar biblioterapia não é uma tarefa fácil. Muitos autores deram sua contribuição, porém é possível notar que ainda não foi possível chegar a um consenso.

Conforme dito anteriormente, a biblioterapia é uma prática antiga, porém Alves (1982, p.55) esclarece que embora o termo já tenha sido usado antes, a sua definição só veio "em 1941 pelo Dicionário Médico 'Dorland’s Illustrated Medical Dictionary' como 'o emprego de livros e de sua leitura no tratamento de doenças mentais". Alves (1982, p.55) complementa que:

o primeiro dicionário, não especializado, a registrá-la foi o 'Webster's Third
International Dictionary', em 1961, como: 'uso de material de leitura
selecionada, como adjuvante terapêutico em Medicina e Psicologia' e
também: 'guia na solução de problemas pessoais através da leitura dirigida',
tendo sido essa adotada oficialmente pela Associação para Bibliotecas de
Hospitais e Instituições.

Atualmente, a maioria dos autores, na tentativa de conceituar biblioterapia, começa citando a etimologia da palavra: "o termo Biblioterapia é derivado do grego "Biblion", que designa todo tipo de material bibliográfico ou de leitura e "Therapein" que significa tratamento, cura ou restabelecimento” (Seitz, 2005, p.90).

Ferreira (2003, p.38) vai mais além ao argumentar que "a Biblioterapia é vista como um processo interativo, resultando em uma integração bem sucedida de valores e ações". E que "o conceito de leitura empregado neste processo interativo é amplo. E inclui todo tipo de material, inclusive os não-convencionais" (FERREIRA, 2003, p. 36).

De acordo com o dicionário Michaelis (online) biblioterapia é o "emprego de leituras selecionadas como adjuvantes terapêuticos no tratamento de desordens nervosas".

Pereira se aproxima dessa conceituação ao afirmar que a "Biblioterapia é a utilização de livros para assistir pessoas no tratamento de problemas nas suas vidas, resolvendo conflitos internos e interpessoais, tratando desgostos e outras emoções fortes ou enfrentando as mudanças indeterminadas da vida" (PEREIRA, [S.d.], p.2). 
Em meio a tantas definições, Rosa (2006, p. 17-19) deu sua contribuição ao organizar as principais citações dos conceitos e dos objetivos da biblioterapia, em ordem cronológica dos registros literários, de acordo com o Quadro 1, apresentado a seguir:

\begin{tabular}{|c|c|c|}
\hline & Conceito de Biblioterapia & Objetivos da Biblioterapia \\
\hline $\begin{array}{l}\text { Alice } \\
\text { Bryan }\end{array}$ & $\begin{array}{l}\text { É a prescrição de } \\
\text { materiais de leitura que } \\
\text { auxiliem a desenvolver } \\
\text { maturidade e nutram e } \\
\text { mantenham a saúde } \\
\text { mental. }\end{array}$ & $\begin{array}{l}\text { Permitir ao leitor verificar que há mais de } \\
\text { uma solução para seu problema; auxiliar } \\
\text { o leitor a verificar suas emoções em } \\
\text { paralelo às emoções dos outros; ajudar } \\
\text { o leitor a pensar na experiência vicária } \\
\text { em termos humanos e não materiais; } \\
\text { proporcionar informações necessárias } \\
\text { para a solução dos problemas, e, } \\
\text { encorajar o leitor a encarar sua situação } \\
\text { de forma realista de forma a conduzir à } \\
\text { ação. }\end{array}$ \\
\hline $\begin{array}{l}\text { L.H. } \\
\text { Tweffort }\end{array}$ & $\begin{array}{l}\text { É um método subsidiário } \\
\text { da psicoterapia; um auxílio } \\
\text { no tratamento que, através } \\
\text { da leitura, busca a } \\
\text { aquisição de um } \\
\text { conhecimento melhor de si } \\
\text { mesmo e das reações dos } \\
\text { outros, resultando em um } \\
\text { melhor ajustamento à } \\
\text { vida. }\end{array}$ & $\begin{array}{l}\text { Fazer a introspecção para o crescimento } \\
\text { emocional; melhorar o entendimento das } \\
\text { emoções; verbalizar e exteriorizar os } \\
\text { problemas; ver objetivamente os os } \\
\text { problemas, afastar a sensação de } \\
\text { isolamento; verificar falhas alheias } \\
\text { semelhantes às suas; aferir valores; } \\
\text { realizar movimentos criativos e estimular } \\
\text { novos interesses. }\end{array}$ \\
\hline $\begin{array}{c}\text { Kenneth } \\
\text { Appel }\end{array}$ & $\begin{array}{l}\text { É o uso de livros, artigos e } \\
\text { panfletos romo } \\
\text { coadjuvantes rán no } \\
\text { tratamento psiquiátrico. }\end{array}$ & $\begin{array}{l}\text { Adquirir informação sobre a psicologia e } \\
\text { a fisiologia do comportamento humano; } \\
\text { capacitar o indivíduo a se conhecer } \\
\text { melhor; criar interesse em algo exterior } \\
\text { ao indivíduo; proporcionar a } \\
\text { familiarização com a realidade externa; } \\
\text { provocar a liberação dos processos } \\
\text { inconscientes; oferecer a oportunidade } \\
\text { de identificação e compensação; } \\
\text { clarificar as dificuldades individuais; } \\
\text { realizar as experiências do outro para } \\
\text { obter a cura e auxiliar o indivíduo a viver } \\
\text { mais efetivamente. }\end{array}$ \\
\hline & & \\
\hline
\end{tabular}




\begin{tabular}{|c|c|c|}
\hline $\begin{array}{c}\text { Louise } \\
\text { Rosenblatt }\end{array}$ & $\begin{array}{l}\text { É uma ajuda para o } \\
\text { ajustamento social e } \\
\text { pessoal; a literatura } \\
\text { imaginativa é útil para } \\
\text { ajustar o indivíduo tanto } \\
\text { em relação aos seus } \\
\text { conflitos íntimos como em } \\
\text { conflitos com outros. } \\
\text { Como o pensamento e } \\
\text { sentimento estão } \\
\text { interligados, o processo de } \\
\text { pensamento reflexivo } \\
\text { estimulado pela leitura é } \\
\text { um prelúdio para a ação. }\end{array}$ & $\begin{array}{l}\text { Divide os objetivos em de cura e de } \\
\text { prevenção. Objetivos de cura: aumentar } \\
\text { a sensibilidade social; ajudar o indivíduo } \\
\text { a se libertar dos medos e das obsessões } \\
\text { de culpa: proporcionar a sublimação por } \\
\text { meio da catarse, e, levar o ser humano a } \\
\text { um entendimento de suas reações } \\
\text { emocionais. Objetivos de prevenção: } \\
\text { prevenir o crescimento de tendências } \\
\text { neuróticas e, conduzir a uma melhor } \\
\text { administração dos conflitos. }\end{array}$ \\
\hline Orsini & $\begin{array}{l}\text { É uma técnica que pode } \\
\text { ser utilizada para fins de } \\
\text { diagnóstico, tratamento e } \\
\text { prevenção de moléstias e } \\
\text { de problemas pessoais. }\end{array}$ & $\begin{array}{l}\text { Classifica os objetivos como sendo de: } \\
\text { nível intelectual, nível social, nível } \\
\text { emocional e nível comportamental. } \\
\text { Assim, a biblioterapia tem como } \\
\text { objetivos: auxiliar o auto-conhecimento } \\
\text { pela reflexão, reforçar padrões sociais } \\
\text { desejáveis, proporcionar } \\
\text { desenvolvimento emocional pelas } \\
\text { experiências vicárias e auxiliar na } \\
\text { mudança de comportamento. }\end{array}$ \\
\hline $\begin{array}{l}\text { Mattews e } \\
\text { Lonsdale }\end{array}$ & $\begin{array}{lr}\text { Constitui-se em } & \begin{array}{r}\text { uma } \\
\text { terapia de } \\
\text { imaginativa, }\end{array} \\
\text { leitura } \\
\text { compreende }\end{array}$ & $\begin{array}{l}\text { Distinguiram três tipos a terapia de } \\
\text { leitura: a de crescimento, a factual e a } \\
\text { imaginativa. Assim, os objetivos são: } \\
\text { divertir e educar (crescimento), informar } \\
\text { e preparar o paciente para o tratamento } \\
\text { hospitalar (factual) explorar os } \\
\text { sentimentos e tratar os problemas } \\
\text { emocionais (imaginativa). }\end{array}$ \\
\hline Caldin & $\begin{array}{l}\text { É a leitura dirigida e } \\
\text { discussão em grupo, que } \\
\text { favorece a interação entre } \\
\text { as pessoas, levando-as a } \\
\text { expressarem reus } \\
\text { sentimentos: os receios, } \\
\text { as angústias e os anseios. }\end{array}$ & $\begin{array}{l}\text { Proporcionar uma forma de as crianças } \\
\text { comunicarem-se, de perderem a timidez, } \\
\text { de exporem seus problemas emocionais } \\
\text { e quiçá físicos; oferecer moderação das } \\
\text { emoções às crianças. }\end{array}$ \\
\hline
\end{tabular}

Fonte: ROSA, 2006, p. 17-19.

Quadro 1 - Conceitos e Objetivos da Biblioterapia 
Esse quadro proporciona uma visão geral das tentativas de conceituar biblioterapia e delimitar seus objetivos. Ajuda a reforçar que não existe um consenso nem quanto à definição nem quanto aos objetivos.

Silva (2005, p. 16) argumenta que "a definição do conceito de Biblioterapia é problemática e que tal definição ainda não apresenta concordância entre os autores que a examinam". Em apêndice, sistematiza por meio de tabelas as definições sobre Biblioterapia encontradas nas fontes documentais examinadas.

No Quadro 2 pode ser observado as definições de biblioterapia que apresentam como núcleo os processos terapêuticos. Nesse quadro, biblioterapia é conceituada como:

- um processo terapêutico (terapia por meio de livros; recurso terapêutico);

- uma terapia auxiliar (terapia auxiliar, atividade auxiliar, auxílio terapêutico, complemento tratamento, coadjuvante no tratamento; apoio à psicoterapia);

- uma técnica;

- uma ferramenta.

\begin{tabular}{|c|c|}
\hline $\begin{array}{l}\text { Conceito } \\
\text { Núcleo }\end{array}$ & Definição \\
\hline \multirow{3}{*}{$\begin{array}{l}\text { Processo } \\
\text { Terapêutico } \\
\text { (Terapia por } \\
\text { meio de livros; } \\
\text { recurso } \\
\text { terapêutico) }\end{array}$} & $\begin{array}{l}\text { 1. MARCONDES, K. A. (2003a) } \\
\text { "Obviamente a Biblioterapia, que é o nome técnico do uso de } \\
\text { "histórias para a vida" não é um recurso maior ou mais } \\
\text { importante que nenhum outro recurso terapêutico. É apenas } \\
\text { mais um recurso. Entretanto, é um recurso totalmente livre de } \\
\text { "contra-indicações" e "efeitos colaterais"”. }\end{array}$ \\
\hline & $\begin{array}{l}\text { 2. PINTO, V. B. (2003) } \\
\text { "Entendemos a Biblioterapia como uma atividade terapêutica } \\
\text { que se utiliza da leitura de textos verbais e não-verbais, da } \\
\text { produção textual, das formas de expressão e de outros objetos } \\
\text { lúdicos como coadjuvante no tratamento de pessoas acometidas } \\
\text { por alguma doença, seja ela física ou mental, ou ainda que } \\
\text { estejam experimentando uma etapa particular ou específica em } \\
\text { suas vidas (...)". }\end{array}$ \\
\hline & $\begin{array}{l}\text { 3. GIANINI, F. H. (1995) } \\
\text { "A biblioterapia é uma terapia fundamentada na leitura dirigida. } \\
\text { Ou seja, pressupõe a atuação de um biblioterapeuta, o qual é o } \\
\text { intermediário entre o leitor e a leitura". (p.7) }\end{array}$ \\
\hline
\end{tabular}




\begin{tabular}{|c|c|}
\hline \multirow{8}{*}{$\begin{array}{l}\text { Terapia auxiliar } \\
\text { (Terapia } \\
\text { auxiliar, } \\
\text { atividade } \\
\text { auxiliar, } \\
\text { auxílio } \\
\text { terapêutico, } \\
\text { complemento } \\
\text { tratamento, } \\
\text { coadjuvante no } \\
\text { tratamento; } \\
\text { apoio à } \\
\text { psicoterapia) }\end{array}$} & $\begin{array}{l}\text { 1. MARCONDES, K. A. (2003b) } \\
\text { "Uso de material selecionado como coadjuvante terapêutico em } \\
\text { medicina e psicologia". Apud Associação de Bibliotecas de } \\
\text { Hospitais e Instituições Correcionais Americanas }\end{array}$ \\
\hline & $\begin{array}{l}\text { 2. PINHEIRO, E. G. (1998a) } \\
\text { "A Biblioterapia é uma técnica que se utiliza da leitura e de } \\
\text { atividades lúdicas como coadjuvante de tratamentos"; (p.4) }\end{array}$ \\
\hline & $\begin{array}{l}\text { 3. CALDIN, C. F. (2001a) } \\
\text { "É o uso de livros, artigos e panfletos como coadjuvantes no } \\
\text { tratamento psiquiátrico". (Appel; p.2) }\end{array}$ \\
\hline & $\begin{array}{l}\text { 4. FONTANELLE, M. F. et all (1995) } \\
\text { "A Biblioterapia é o uso de materiais de leitura selecionados } \\
\text { como auxiliares terapêuticos em medicina e psiquiatria, e } \\
\text { também auxílio na solução de problemas por meio de leitura } \\
\text { dirigida". (Webster International, 1961) (p.2) }\end{array}$ \\
\hline & $\begin{array}{l}\text { 5. RODRIGUES, M. S. (2002) } \\
\text { "Destaca-se a Biblioterapia que, como prática leitora, utiliza-se de } \\
\text { textos verbais e não verbais como coadjuvantes no tratamento } \\
\text { de pessoas acometidas por doenças físicas ou mentais ou, } \\
\text { ainda, que enfrentam momentos de crise ou de dificuldades". } \\
\text { (p.1) }\end{array}$ \\
\hline & $\begin{array}{l}\text { 6. PINHEIRO, E. G. (2002) } \\
\text { "A Biblioterapia é uma técnica que se utiliza da leitura e de } \\
\text { atividades lúdicas como coadjuvante de tratamentos"; (p.4) }\end{array}$ \\
\hline & $\begin{array}{l}\text { 7. MENEZES, L. S. (2002) } \\
\text { "Tratamento terapêutico auxiliar". (p.7) }\end{array}$ \\
\hline & $\begin{array}{l}\text { 8. FENÁNDEZ-VÁSQUEZ, M. S. A. (1989) } \\
\text { "A Biblioterapia, ou "medicina do intelecto", é um complemento } \\
\text { extremamente importante no tratamento do paciente". (p.30) } \\
117\end{array}$ \\
\hline
\end{tabular}


9. SCHLACHTER, L. (1999)

"A Biblioterapia, como coadjuvante em tratamentos, teve início por volta de 1800, com Benjamim Rush, um americano que aconselhava 0 uso da leitura como forma de apoio à psicoterapia, para doentes mentais e para qualquer pessoa com conflitos internos". (p.312)

11. CALDIN, C. F. (2001b)

"A Associação das Bibliotecas de Instituições e Hospitais dos Estados Unidos (Mood; Limper, 1973), adotou como definições de biblioterapia: a utilização de materiais de leitura selecionados como coadjuvante terapêutico na medicina e na psiquiatria". (p.5)

12. RATTON, A. M. L. (1975)

"Uso de material de leitura selecionada, como adjuvante terapêutico em Medicina e Psicologia" e também: "Guia na solução de problemas pessoais através da leitura dirigida". (Webster's Third International Dictionary) (p.199)

13. ALVES, M. H. H. (1982)

"Uso de material de leitura selecionada, como adjuvante terapêutico em Medicina e Psicologia" e também: "Guia na solução de problemas pessoais através da leitura dirigida". (Webster's Third International Dictionary) (p.55)

14. SOUZA, K.; BOTELHO, R. (2004)

"Uso de material selecionado como coadjuvante terapêutico em Medicina e Psicologia". (p.2)

15. QUEIROZ, M. P. C. P. (2003) "Método subsidiário da psicoterapia; um auxílio no tratamento que, através da leitura, busca a aquisição de um conhecimento melhor de si mesmo e das reações dos outros, resultando em um melhor ajustamento à vida" (apud L.H.Tweffort) (p.32) 


\begin{tabular}{|c|c|}
\hline \multirow[t]{6}{*}{ Técnica } & $\begin{array}{l}\text { 1. ORSINI, M. S. (1982) } \\
\text { "O termo Biblioterapia não envolve o tratamento; trata-se de uma } \\
\text { técnica largamente usada, tanto para fins de diagnóstico, como } \\
\text { também medida profilática. Isso equivale dizer que, em termos } \\
\text { gerais, a Biblioterapia pode ser vista sob o prisma de diagnóstico, } \\
\text { tratamento e prevenção". (p.145) }\end{array}$ \\
\hline & $\begin{array}{l}\text { 2. FERREIRA, D. T. (2003) } \\
\text { "O componente que torna a Biblioterapia uma técnica de } \\
\text { aconselhamento é naturalmente um biblioterapeuta que pode ser } \\
\text { qualquer um dos profissionais que atuarão conjuntamente neste } \\
\text { programa (psicólogo, educador, bibliotecário ou assistente } \\
\text { social". (p.36) }\end{array}$ \\
\hline & $\begin{array}{l}\text { 3. HASSE, M. (2004) } \\
\text { "Apresenta-se nesta dissertação a investigação de um fenômeno } \\
\text { comunicativo particular - uma técnica psicoterapêutica chamada } \\
\text { Biblioterapia". (p.1) }\end{array}$ \\
\hline & $\begin{array}{l}\text { 4.PINHEIRO, E. G. (1998) } \\
\text { "A Biblioterapia é uma técnica que se utiliza da leitura e de } \\
\text { atividades lúdicas como coadjuvante de tratamentos"; (p.4) }\end{array}$ \\
\hline & $\begin{array}{l}\text { 4. MATOS, C. R. M.; QUEIROZ, M. P. C. P. (2003) } \\
\text { "A Biblioterapia é uma técnica que se utiliza da leitura e outras } \\
\text { atividades lúdicas como coadjuvante no tratamento de pessoas } \\
\text { acometidas por alguma doença física ou mental. É aplicada } \\
\text { como educação e reabilitação em indivíduos em diversas faixas } \\
\text { etárias". (p.2) }\end{array}$ \\
\hline & $\begin{array}{l}\text { 5. OLIVEIRA, P. L. (2002) } \\
\text { "A Biblioterapia é uma técnica de tratamento que busca através } \\
\text { da leitura o auto conhecimentocom o objetivo de curar o usuário } \\
\text { de moléstias psicossociais e físicas". (p.3) }\end{array}$ \\
\hline $\begin{array}{l}\text { Ferramenta } \\
\text { (instrumento) }\end{array}$ & $\begin{array}{l}\text { 1. CALDIN, C. F. (2003) } \\
\text { "A Biblioterapia é uma ferramenta útil no combate às tensões da } \\
\text { vida diária e age como pacificadora das emoções ao realizar a } \\
\text { catarse pela fruição do literário e satisfazer as necessidades } \\
\text { estéticas do ser humano". (p.10) }\end{array}$ \\
\hline & \\
\hline
\end{tabular}




\begin{tabular}{|c|l|}
\hline Método & 1. \\
subsidiário de & \\
Psicoterapia & \\
\hline
\end{tabular}

Fonte: SILVA, 2005, p. 116-118.

Quadro 2 - Definições de Biblioterapia que apresentam como núcleo os processos terapêuticos

As definições de biblioterapia, apresentadas no Quadro 3, mostram como núcleo os processos de socialização, a partir da conceituação da biblioterapia como:

- uma prática social;

- um processo dinâmico, interativo, de desenvolvimento, clínico, de estudo;

- um modo de Comunicação.

\begin{tabular}{|c|c|}
\hline Conceito Núcleo & Definição \\
\hline Prática Social & 1. - \\
\hline \multirow[t]{3}{*}{$\begin{array}{l}\text { Processo dinâmico, } \\
\text { interativo, de } \\
\text { desenvolvimento, } \\
\text { clínico, de } \\
\text { estudo; }\end{array}$} & $\begin{array}{l}\text { 1. CRUZ, M. A. (1995) } \\
\text { "Biblioterapia pode ser tanto um processo de } \\
\text { desenvolvimento pessoal como um processo clínico de } \\
\text { cura, que utiliza literatura selecionada, filmes, e participantes } \\
\text { que desenvolvem um processo de escrita criativa com } \\
\text { discussões guiadas por um facilitador treinado com o } \\
\text { propósito de promover a integração de sentimentos e } \\
\text { pensamentos a fim de promover autoafirmação, auto } \\
\text { conhecimento ou reabilitação". (LACK apud MARCINKO, } \\
\text { 1989) (p.15) }\end{array}$ \\
\hline & $\begin{array}{l}\text { 2. CALDIN, C. F.; BUENO, S. B. (2002) } \\
\text { "Com a união destes dois termos, leitura e terapia, surgiu a } \\
\text { biblioterapia, definida como um processo dinâmico de } \\
\text { interação entre o leitor, o texto e o ouvinte, ajudando no } \\
\text { crescimento emocional e psicológico". (p.158) }\end{array}$ \\
\hline & $\begin{array}{l}\text { 3. SPERANDIO, S. M. (1978) } \\
\text { "Processo de interação entre a personalidade do leitor e a } \\
\text { leitura de ficção". (p.6) }\end{array}$ \\
\hline
\end{tabular}




\begin{tabular}{|c|l|}
\hline & $\begin{array}{l}\text { 4. OLIVEIRA, P. L. (2002) } \\
\text { "Biblioterapia como sendo um processo dinâmico de } \\
\text { interação entre a personalidade do leitor e as leituras } \\
\text { imaginativas, que pode atrair as emoções do leitor e liberá- } \\
\text { las para o uso consciente e produtivo". (p.4) }\end{array}$ \\
\hline $\begin{array}{c}\text { Modo de } \\
\text { Comunicação }\end{array}$ & $1 .-$ \\
\hline
\end{tabular}

Fonte: SILVA, 2005, p. 119.

\section{Quadro 3 - Definições de Biblioterapia que apresentam como núcleo os processos de} socialização

Outras definições de biblioterapia, tendo como núcleo os seus procedimentos e agentes, são demonstradas no Quadro 4:

- uma leitura dirigida;

- um programa de atividades;

- uma prescrição de materiais;

- um aconselhamento de leitura.

\begin{tabular}{|c|c|}
\hline $\begin{array}{l}\text { Conceito } \\
\text { Núcleo }\end{array}$ & Definição \\
\hline Leitura Dirigida & $\begin{array}{l}\text { 1. RATTON, A. M. L. (1975) } \\
\text { "Guia na solução de problemas pessoais através da leitura } \\
\text { dirigida". (Webster's Third International Dictionary) (p.199) }\end{array}$ \\
\hline & $\begin{array}{l}\text { 1. PEREIRA, M. M. G. (2000) "Biblioterapia - programa de } \\
\text { leitura orientada". (p.7) }\end{array}$ \\
\hline $\begin{array}{l}\text { Programa de } \\
\text { Atividades }\end{array}$ & $\begin{array}{l}\text { 2. SEITZ, E. M. (2000) } \\
\text { A Biblioterapia é um programa de atividades selecionadas } \\
\text { envolvendo materiais de leitura, planejadas e conduzidas e } \\
\text { controladas como um tratamento, sob orientação médica, para } \\
\text { problemas emocionais e de comportamento. Devendo ser } \\
\text { administrada por um bibliotecário treinado de acordo com as } \\
\text { propostas e finalidades prescritas. (p.10) }\end{array}$ \\
\hline $\begin{array}{l}\text { Prescrição de } \\
\quad \text { Materiais }\end{array}$ & 1. - \\
\hline
\end{tabular}


Aconselhamento de Leitura
1. PEREIRA, M. M. G. (1996)

Biblioterapia é uma aplicação refinada de uma função normal de aconselhamento de leitura. (p.39)

Fonte: SILVA, 2005, p. 120.

\section{Quadro 4 - Definições de Biblioterapia que apresentam como núcleo os procedimentos de agentes da Biblioterapia}

No Quadro 5 as definições de biblioterapia apresentam como núcleo as relações estabelecidas com o livro, como:

- uma prática leitora;

- filosofia do livro.

\begin{tabular}{|c|c|c|}
\hline Conceito Núcleo & Definição & $\begin{array}{c}\text { Quantidade } \\
\text { de x que } \\
\text { aparece } \\
\text { repetida }\end{array}$ \\
\hline \multirow{4}{*}{ Prática Leitora } & $\begin{array}{l}\text { 1. PINTO, V. B. et all (2001) } \\
\text { "As práticas leitoras se constroem } \\
\text { multidisciplinarmente e, neste contexto, } \\
\text { destaca-se a Biblioterapia que, como prática } \\
\text { leitora, utiliza-se de textos - verbais e não- } \\
\text { verbais - como coadjuvantes no tratamento de } \\
\text { pessoas". (Resumo) }\end{array}$ & 2 \\
\hline & $\begin{array}{l}\text { 2. RODRIGUES, M. S. (2002) } \\
\text { "Destaca-se a Biblioterapia que, como prática } \\
\text { leitora, utiliza se de textos verbais e não- } \\
\text { verbais como coadjuvantes no tratamento de } \\
\text { pessoas acometidas por doenças físicas ou } \\
\text { mentais ou, ainda, que enfrentam momentos } \\
\text { de crise ou de dificuldades". (p.1) }\end{array}$ & 1 \\
\hline & $\begin{array}{l}\text { 3. PINTO, V. B. et all (2002) } \\
\text { "Enquanto prática leitora, a biblioterapia se } \\
\text { apropria de diversos mecanismos de leituras } \\
\text { de textos verbais e não-verbais para auxiliar } \\
\text { no tratamento de pessoas doentes ou que } \\
\text { estejam enfrentando momentos de crise, } \\
\text { dificuldades (...)" }\end{array}$ & 1 \\
\hline & 1 & - \\
\hline
\end{tabular}


\begin{tabular}{|l|l|l|}
\hline Filosofia do Livro & & \\
\hline
\end{tabular}

Fonte: SILVA, 2005, p. 121.

\title{
Quadro 5 - Definições de Biblioterapia que apresentam como núcleo as Relações estabelecidas com o livro
}

Não há como determinar qual dessas definições é a correta. Todas são adequadas, cada uma a sua realidade. Fatores como local, profissional envolvido e o 'cliente' assistido por essa prática atuarão como delimitadores da definição e dos objetivos da biblioterapia.

\subsubsection{O Universo Biblioterapêutico}

\section{- A função terapêutica da leitura}

A leitura como função terapêutica é a terapia feita por meio de textos literários que podem promover a pacificação das emoções. E "muito embora a palavra terapia, em termos restritivos, possua um sentido curativo, na realidade envolve muito mais do que a cura - implica em uma atitude preventiva" (CALDIN, 2001, p.3738).

\begin{abstract}
A leitura implica uma interpretação - que é em si mesma uma terapia, posto que evoca a idéia de liberdade - pois permite a atribuição de vários sentidos ao texto. O leitor rejeita o que lhe desgosta e valoriza o que lhe apraz, dando vida e movimento às palavras, numa contestação ao caminho já traçado e numa busca de novos caminhos. A biblioterapia contempla não apenas a leitura, mas também o comentário que Ihe é adicional. Assim, as palavras se seguem umas às outras - texto escrito e oralidade, o dito e 0 desdito, a afirmação e a negação, o fazer e o desfazer, o ler e o falar - em uma imbricação que conduz à reflexão, ao encontro das múltiplas verdades, em que o curar se configura como o abrir-se a uma outra dimensão (CALDIN, 2001, p.36).
\end{abstract}

Seitz (2005, p.97) complementa isso ao dizer que por meio da leitura é possível que o leitor incorpore ao personagem do livro e faça uma viagem emocionante e ao voltar dessa viagem, o leitor esteja diferente "pois algo de fundamental sobre seu ser e do seu desejo pode ser revelado e provocado. O leitor pode, ainda, encontrar personagens com problemas semelhantes aos seus, ou ainda, iguais aos seus, o que pode contribuir the dando incentivo para superar seus 
próprios problemas." Ou seja, "toda pessoa ao ler constrói um texto paralelo intimamente relacionado ao texto que está sendo lido. Este texto paralelo está intimamente relacionado às suas experiências e vivências pessoais, desta forma o mesmo texto tornando-se um texto diferente para cada leitor" (FERREIRA, 2003, p. 42). Dessa maneira, essas diferentes interpretações fazem com que exista a "alteridade e a criação de novos sentidos" (CALDIN, 2001, p.37). Já que "conceitos podem ser transmitidos, mas significados são pessoais e intransferíveis" (FERREIRA, 2003, p. 42).

\section{- Elementos biblioterapêuticos}

Por meio da literatura consultada foi possível observar que os elementos biblioterapêuticos são estruturados de maneiras diferentes. Por alguns autores, "os elementos presente na biblioterapia são comparáveis aos da psicoterapia: universalização, identificação, catharsis e 'insight”' (Alves, 1982, p.56). Caldin (2001) não cita o insight, e além da identificação e a 'catharsis', cita o humor, a introjeção e a introspecção como componente da biblioterapia. Ao estudar essas duas formas é perceptível que na prática não existe muita diferença entre elas, porém a maneira como Caldin (2001) estrutura esses elementos facilita na compreensão do funcionamento da biblioterapia, por esse motivo será essa estrutura a explorada nessa monografia.

\section{a) A catarse}

No dicionário médico online consultado catarse é definida como um "elemento de técnica psicanalítica e psicoterápica que visa à remissão dos sintomas através de exteriorização verbal e emocional dos traumatismos afetivos reprimidos; purgação; evacuação; limpeza." "Dessa forma, catarse pode ser entendida como pacificação, serenidade e alívio das emoções. É nessa perspectiva que se enfoca a leitura de textos literários como desempenhando uma função catártica" (CALDIN, 2001, p.38).

Em outro artigo Caldin (2005) comenta a entrevista que fez com o professor Doutor em ontologia e história da filosofia, Marcos José Müller, do departamento de filosofia da Universidade Federal de Santa Catarina. Nessa entrevista o professor diz que 
[...] a catarse seria, por um lado, meio, e por outro lado, efeito da tragédia. Enquanto meio, ela é uma função direta. Enquanto efeito, ela é uma função ulterior. Enquanto meio, ou função direta, a catarse é o que permite-nos a transferência de nossos conflitos morais e afetivos às personagens. Dessa forma, poderíamos enfim enfrentá-los, por se tratar de conflitos não diretamente nossos. Enquanto efeito, ou função indireta, a catarse é a relativização da intensidade de nossos conflitos, ou a moderação dos mesmos. De modo que se pode genericamente falar da catarse como uma moderação dos nossos sentimentos (de temor) por meio da representação desses sentimentos junto a uma personagem (porque nos compadecemos). O efeito catártico seria a sublimação, em que a transferência dos sofrimentos da pessoa para a personagem ocasionaria um alívio. Assim, ver o nosso sofrimento no outro conduziria à paz. Como não conseguimos ver a nossa verdade, vemos a verdade no herói trágico. Isto causaria um efeito de suspensão, de purificação, de eliminação dos sentimentos, porque poderse-ia lidar com os mesmos na personagem. O efeito ulterior é o sentir-se aliviado, atenuar o próprio sentimento pela purificação das emoções. Assim, a purificação só é possível pela produção das emoções. A tragédia causa emoções e as modera. Ter compaixão e temor é ver na personagem seus próprios medos, sua própria condição; representar estas emoções para si mesma é tê-las sob domínio, significa não mais ser vítima delas. Quando se representam esses temores para si mesmo, eles podem ser medidos. A catarse seria, portanto, a justa medida dos sentimentos modera os sentimentos, produzindo-os (MÜLLER apud CALDIN, 2005, p.14).

b) $O$ humor

Freud (apud CALDIN, 2001, p. 38) definiu humor como "[...] a rebelião do ego contra as circunstâncias adversas, transformando o que poderia ser objeto de dor em objeto de prazer. É a ação do superego agindo sobre o ego a fim de protegê-lo contra a dor." Por esse motivo considera que o humor encontrado na leitura pode ser usado de forma terapêutica.

Os benefícios que o humor acarreta na vida de um individuo são notáveis, e são explicados fisiologicamente. De acordo com o Dr. Eduardo Lambert (apud Milomem, 2006)

clínico geral, homeopata e terapeuta, autor do livro "Terapia do Riso - A Cura pela Alegria", o riso e sua onda vibratória transmitem energia e uma química que se espalha por todo o corpo, provocando o relaxamento muscular de todos os órgãos. "Mesmo o simples esboçar de um sorriso ou uma gargalhada, estimulam o cérebro a produzir endorfinas, substâncias químicas com poder analgésico, que proporcionam uma enorme sensação de bem-estar". Além disso, acrescenta Lambert, "as endorfinas estimulam o sistema imunológico contra reações alérgicas, bactérias e vírus; protegem o aparelho circulatório contra enfartes e derrames; ajudam a melhorar a pressão arterial, ampliam a capacidade respiratória e promovem uma ação anti-envelhecimento. 
Por se tratar de um meio que proporciona inúmeros benefícios e por poder ser estimulado pela leitura, foi incluído como mais um elemento aplicado na biblioterapia.

c) A identificação

"Segundo o Vocabulário de Psicanálise (LAPLANCHE; PONTALIS, apud CALDIN, 2001, p.38-39), a identificação é "um processo psicológico pelo qual um sujeito assimila um aspecto, uma propriedade, um atributo do outro e se transforma, total ou parcialmente, segundo o modelo desse outro." Caldin (2005, p.16) explica, que a identificação com um personagem quase sempre acontece inconscientemente, e possibilita que o leitor experimente "situações por vezes impossíveis na vida real." E avalia como "essencial à biblioterapia a concepção de que o sujeito possui uma identidade em movimento ou a identidade dinâmica."

\section{d) A introjeção}

De acordo com o dicionário médico online consultado, a introjeção é o "dinamismo psicológico em que o indivíduo considera como seus os sentimentos, atitudes, restrições, proibições e, mesmo, gestos e características de outrem (pais, parentes ou pessoas ligadas ou indivíduo)." Com essa definição é possível perceber que a introjeção "está estreitamente relacionada com a identificação" CALDIN (2001, p.39).

e) A projeção

O dicionário Aurélio (s.d) define projeção (no contexto da psicanálise) como "[...] Mecanismo pelo qual o ser humano atribui a outra pessoa seus próprios sentimentos e motivações [...]." A definição dada por Caldin (2001, p.39) se assemelha a essa: "a projeção é a transferência aos outros de nossas idéias, sentimentos, intenções, expectativas e desejos." 
f) A introspecção

Ao consultar o dicionário Michaelis (s.d.) encontra-se a seguinte definição para introspecção:

sf (lat introspectione) Psicol 1 Descrição da experiência pessoal em termos de elementos e atitudes. 2 Observação, por uma determinada pessoa, de seus próprios processos mentais; os psicólogos experimentalistas julgam irrealizável a introspecção nesta acepção; não obstante, admitem a introspecção provocada, método que consiste em submeter uma pessoa a estimulações definidas que reclamem resposta imediata, seguindo-se 0 relato dos estados subjetivos que a pessoa haja experimentado. Var: introspeção.

Embora não seja um dicionário especializado, não se diferencia muito da definição oferecida por pelo dicionário médico on-line pesquisado que conclui que introspecção é um "método de análise em que o indivíduo observa sua própria personalidade; auto-análise."

É possível concluir então que "a leitura, ao favorecer a introspecção, leva o indivíduo a refletir sobre os seus sentimentos - o que é terapêutico, pois sempre desponta a possibilidade de mudança comportamental” (CALDIN, 2001, p. 39).

\subsubsection{Aplicação da Biblioterapia}

A literatura estudada fornece subsídios suficientes para afirmaa que a biblioterapia está inserida em diferentes contextos. Tanto o ambiente onde é aplicada, como o público assistido, a técnica utilizada, o profissional envolvido, entre outros, variam. É possível ilustrar isso no Quadro 6, onde Pereira (1996, p. 59) classifica biblioterapia em institucional, clínica e desenvolvimental:

\begin{tabular}{|c|c|c|c|}
\hline $\begin{array}{c}\text { Tipos } \\
\text { Aspectos }\end{array}$ & Institucional & Clínica & Desenvolvimental \\
\hline Formato & $\begin{array}{c}\text { Individual ou grupo } \\
\text { geralmente passivo }\end{array}$ & $\begin{array}{c}\text { Grupo ativo } \\
\text { voluntário e } \\
\text { involuntário }\end{array}$ & $\begin{array}{c}\text { Grupo ativo } \\
\text { Grupo voluntário }\end{array}$ \\
\hline Cliente & Paciente médico ou & $\begin{array}{c}\text { Pessoas com } \\
\text { problemas }\end{array}$ & $\begin{array}{c}\text { Pessoa normal, } \\
\text { geralmente em }\end{array}$ \\
\hline
\end{tabular}




\begin{tabular}{|c|c|c|c|}
\hline & $\begin{array}{c}\text { psiquiátrico, } \\
\text { prisioneiro ou } \\
\text { cliente em prática } \\
\text { privada }\end{array}$ & $\begin{array}{l}\text { emocional ou } \\
\text { comportamental }\end{array}$ & situação de crise \\
\hline Contratante & Sociedade & $\begin{array}{l}\text { Sociedade ou } \\
\text { individual }\end{array}$ & Individual \\
\hline Terapêutica & $\begin{array}{l}\text { Equipe médica e } \\
\text { bibliotecária }\end{array}$ & $\begin{array}{l}\text { Médico, instrutor } \\
\text { de saúde mental } \\
\text { ou bibliotecário } \\
\text { geralmente em } \\
\text { consulta }\end{array}$ & $\begin{array}{c}\text { Bibliotecário, professor } \\
\text { ou outros }\end{array}$ \\
\hline Material usado & $\begin{array}{l}\text { Tradicionalmente } \\
\text { didático }\end{array}$ & $\begin{array}{l}\text { Literatura } \\
\text { imaginativa }\end{array}$ & $\begin{array}{l}\text { Literatura imaginativa } \\
\text { e/ou didática }\end{array}$ \\
\hline Técnica & $\begin{array}{l}\text { Discussão de } \\
\text { material }\end{array}$ & $\begin{array}{l}\text { Discussão de } \\
\text { material, com } \\
\text { ênfase nas visões } \\
\text { e reações do } \\
\text { cliente }\end{array}$ & $\begin{array}{l}\text { Discussão de material, } \\
\text { com ênfase nas } \\
\text { reações do cliente }\end{array}$ \\
\hline Local & $\begin{array}{c}\text { Prática de } \\
\text { Instituição pública } \\
\text { ou privada }\end{array}$ & $\begin{array}{c}\text { Prática de } \\
\text { Instituição privada } \\
\text { ou de comunidade }\end{array}$ & Comunidade \\
\hline Meta & $\begin{array}{l}\text { Geralmente } \\
\text { Informativo, com } \\
\text { alguma visão } \\
\text { interno }\end{array}$ & $\begin{array}{l}\text { Visão interna e/ou } \\
\text { mudanças de } \\
\text { comportamento }\end{array}$ & $\begin{array}{l}\text { Comportamento } \\
\text { normal ou auto- } \\
\text { realização }\end{array}$ \\
\hline
\end{tabular}

Fonte: PEREIRA, 1996, p. 59

\section{Quadro 6 - Características dos três tipos de biblioterapia}

Esse quadro sistematiza a forma como a prática biblioterapêutica deverá ser desenvolvida em determinados contextos, na prática, o profissional atuante não deve limitar-se a segui-lá. 


\title{
4.1.5 Profissionais envolvidos
}

"Em 1914, a biblioterapia passa a ser considerada como um ramo da biblioteconomia, quando uma certa bibliotecária, assumindo a direção de uma biblioteca hospitalar, em Massachusetts, resolve fazer suas próprias experiências" (ALVES, 1982, p. 55). Apesar disso, ainda não existe um consenso que o profissional apto a exercer a função de biblioterapêutico seja o bibliotecário, pois

\begin{abstract}
alguns autores acham que cabe a eles, tão somente, a escolha do material empregado. Outros acham que, graças ao seu "background", eles estão gabaritados para aplicar a biblioterapia, bastando apenas um treinamento especial. O fato é que as primeiras experiências foram feitas por médicos em bibliotecas hospitalares. Nas instituições correcionais americanas, a biblioterapia é aplicada por bibliotecários, enquanto que nos hospitais eles apenas auxiliam o terapeuta na busca e seleção do material empregado (ALVES, 1982, p. 55-56).
\end{abstract}

Ferreira (2003, p.40) cita o que inclui esse 'treinamento especial' que foi citado anteriormente:

[...] treinamento prático em liderança e organização de grupos, aulas teóricas, leituras sobre o assunto, e workshops para reciclagem e avaliação. Este treinamento é fornecido por associações como a ALA (The American Library Association), que possui uma organização dedicada exclusivamente ao assunto, a Biblioterapy Fórum, que faz parte da Divisão da Associação e Cooperativa das Bibliotecas Associadas (ASCLA), e pela NAPT (The Nacional Association of Poetry Therapy) ou por entidades psicológicas como as Associações Profissionais e as Associações Científicas.

Além de bibliotecários, profissionais como psicólogos, enfermeiros, psiquiatras e terapeutas ocupacionais também podem atuar na biblioterapia (ALVES, 1982).

Voltando-se para as atividades biblioterapêuticas realizadas por bibliotecários observa-se que existem muitos relatos que expõem casos práticos da área, principalmente em meio acadêmico.

Pinto (2005, p.40) exemplifica bem isso, ao afirmar que:

No Brasil, as experiências com a biblioterapia foram implementadas em hospitais de São Paulo, no Instituto dos Cegos em João Pessoa, Instituto dos Cegos da Paraíba "Adalgisa Cunha", em hospitais de Belém, etc. No Ceará, o Curso de Biblioteconomia da Universidade Federal do Ceará foi o pioneiro da biblioterapia, com um projeto de pesquisa implantado no bloco de oncologia do Hospital Infantil Albert Sabin, para crianças com câncer, 
tendo lá permanecido até dezembro de 2000. Em 1995, outro projeto foi posto em prática no "Lar Torres de Melo", com pessoas idosas. Mais um projeto na mesma linha foi implantado na "Casa de Nazaré", em 2000. A partir de março 2001 registrou-se outra experiência com crianças, residentes na "Casa da Criança", onde aconteceu até março de 2003. Tais experiências são implementadas como projetos interdisciplinares, notadamente entre os cursos de Biblioteconomia, Letras e Psicologia, por intermédio do Núcleo Cearense de Pesquisa da Criança (NUCEPEC). Seus resultados já somam vários artigos apresentados e publicados em anais de eventos nacionais e internacionais, assim como uma dissertação de mestrado, defendida por Edna Gomes Pinheiro, no Curso de Mestrado em Ciência da Informação (UFPB).

A divulgação desse tipo de trabalho seja em forma de artigos, congressos, seminários, ou simpósios, possibilita "um espaço de organização e troca de informações e experiências que auxilie o desenvolvimento de Biblioterapia brasileira como um campo de pesquisa e intervenção sistematizado" (SILVA 2005, p. 65).

Infelizmente nem todas as universidade de biblioteconomia no Brasil possuem biblioterapia na grade curricular, porém as que possuem colaboram para que o bibliotecário seja reconhecido como um profissional atuante na área.

\subsection{Planejamento}

\subsubsection{Novos paradigmas da Sociedade da Informação e do Conhecimento}

"Tanto no cenário mundial quanto no Brasil, vive-se uma palavra de ordem que cerca, impulsiona, agride e até sufoca o indivíduo. Esta palavra é MUDANÇA" (BORGES, 2000, p. 25).

Vivenciada desde o momento em que se partiu de um período de especialização, onde se estudava a essência de cada ciência isoladamente, para o período de agregação, onde as diferentes áreas do conhecimento existentes são estudadas em conjunto (BORGES, 2000), essa mudança de paradigma provocada pelo deslocamento da sociedade industrial para a sociedade da informação, "tem como pano de fundo a sofisticação das tecnologias de informação que rompem limites de tempo e distância, transpondo barreiras sociais, culturais e políticas, tornando o mundo mais integrado" (BORGES, 1995, p. 1).

Esses fatores, em conjunto, levam a crer que "na sociedade do conhecimento, a informação, gerando ação (conhecimento), constitui o mais importante recurso de 
agregação de valor" (LASTRES, 1999, p. 2) tanto em nível organizacional quanto em nível pessoal, pois, as mudanças vivenciadas exigem que as pessoas sejam capacitadas, não apenas em leitura e escrita, mas também em outras áreas que incluem o conhecimento de computação e sistemas políticos, bem como de sistemas históricos e sociais.

Neste contexto onde "informação e conhecimento passam a assumir papel ainda mais visível e estratégico na nova ordem estabelecida, baseando e alavancando as novas possibilidades de crescimento" (LASTRES, 1999, p. 2), a informação desempenha um papel decisivo na evolução da sociedade, pois além de gerar conhecimento é fundamental em qualquer tomada de decisão. Ela surge, como um quarto setor na economia, envolvendo um grande número de profissionais e fornecendo subsídios para o desenvolvimento da sociedade.

Para Lastres (1999, p.5) essa nova demanda além de tornar necessária mudanças no ambiente físico das grandes e pequenas organizações, faz com que elas reestruturem suas funções e atividades, bem como implementem novas estratégias de atuação por meio do desenvolvimento de novos desenhos organizacionais e instrumentos, e metodologias operacionais previamente planejados.

Frente às novas mudanças vivenciadas, que afetam diretamente tanto as organizações como os seres humanos, Borges conclui que a sociedade da informação e do conhecimento é uma realidade, pois (2000, p. 31):

o mundo está se preparando para dar mais um salto, através das novas
tecnologias e das novas redes. Tanto do ponto de vista dos benefícios
socais que trará aos cidadãos, à comunidade, às nações, bem como dos
benefícios econômicos que advirão com a ampliação das oportunidades de
educação, da formação profissional, da diminuição do desemprego, das
novas oportunidades de mercado, do desenvolvimento dos setores
produtivos.

Nesse contexto de mudança e incerteza, para que a organização possa ter êxito, é necessária a programação das atividades a serem desenvolvidas, de modo que a tomada de decisão se adéqüe aos objetivos que se deseja alcançar. Esta programação se dá por meio do processo de planejamento, que nada mais é do que uma preocupação com o futuro da empresa baseada no gerenciamento das atividades e informações vivenciadas no presente. 


\subsubsection{Conceitos e finalidades}

Planejar é reconhecidamente um processo imprescindível nas organizações, tendo em vista os benefícios que pode trazer para quem o faz de maneira correta, ou seja, eficiente e eficazmente. Seu uso, cada dia mais freqüente na realização de atividades do dia-a-dia, faz com que as organizações, que antes optavam pela improvisação - como é comumente conhecida - passem a utilizar o planejamento, pois o mesmo às leva a obtenção do sucesso ao final de uma jornada, por meio do aperfeiçoamento de ações e alcance dos objetivos previamente traçados.

"Toda atividade de planejamento [...] deverá resultar de decisões presentes, tomadas a partir do exame do impacto das mesmas no futuro" (OLIVEIRA, 2007, p. 5), sendo que deverão, ao longo do processo, ser constantemente avaliadas e repensadas quando necessário.

Mas afinal, o que é o planejamento e porque planejar?

O planejamento é "a função administrativa que determina antecipadamente quais são os objetivos que devem ser atingidos e como se deve fazer para alcançálos" (CHIAVENATO, 2000, p. 195). Além disso, de acordo com Almeida (2005, p. 2) "é um processo continuo, permanente e dinâmico, que fixa objetivos, define linhas de ação, detalha as etapas para atingi-los e prevê os recursos necessários à consecução desses objetivos".

Esse processo "envolve, portanto, um modo de pensar; e um salutar modo de pensar envolve indagações; e indagações envolvem questionamentos sobre o que fazer, como, quando, quanto, para quem, por que, por quem e onde" (OLIVEIRA, 2007, p. 5), sendo que é por meio dele, conforme cita Chiavenato (2000), que as organizações definem onde elas pretendem chegar, o que deve ser feito para alcançarem seus objetivos, quando e como deve ser feito e em que seqüência deve ser feito.

Para Oliveira (2007, p.5) "o exercício sistemático do planejamento tende a reduzir a incerteza envolvida no processo decisório, e conseqüentemente provoca o aumento da probabilidade de alcance dos objetivos, desafios e metas estabelecidas pela empresa". Ainda assim, existem inúmeros questionamentos com relação aos reais objetivos do processo de planejamento, fazendo com que muitas pessoas se perguntem o porquê planejar. A resposta para tais questionamentos é simples e os 
benefícios obtidos pelas instituições que fazem uso do planejamento na realização das atividades, são diversos.

Planejar faz com que as organizações alcancem o sucesso esperado na realização de suas atividades, sendo esse o maior beneficio para as mesmas. Entretanto, as vantagens da utilização do planejamento não se resumem a isso, pois, conforme cita Almeida (2005), sua utilização permite também à redução do grau de incerteza, a limitação de ações arbitrárias, a diminuição de riscos, ao mesmo tempo em que se dá rentabilidade máxima aos recursos. Planejar torna ainda possível a realização de eventos que não aconteceriam se não tivessem sido previamente planejados; permite que as organizações tirem proveito de oportunidades, pois a partir de uma analise estratégica de ameaças e oportunidades, a tomada de decisão se torna mais concreta; o ambiente organizacional se torna mais equilibrado e produtivo na medida em que as decisões planejadas passam a dar maior estabilidade à organização.

Para Jones e Jorge (2008) o planejamento permite, que todos participem da tomada de decisão, tornando possível a mobilização de recursos para lidar com futuras oportunidades e ameaças.

\subsubsection{Instrumentos do Planejamento}

Almeida (2005) afirma que o sucesso do processo de planejamento só é possível por meio do emprego de diferentes instrumentos, que quando utilizados em conjunto garantem a eficiência e eficácia do processo. Dentre os principais destacam-se:

\section{- Plano}

Resultado final do processo de planejamento, porém não mais importante que o processo em si, "todos os planos têm um propósito comum: a previsão, a programação e a coordenação de uma seqüência lógica de eventos, os quais deverão conduzir ao alcance dos objetivos que os comandam" (CHIAVENATO, 2000 , p. 199). Diferentemente do processo de planejamento, que é um processo permanente, Born (2007) afirma que o plano é apenas um resultado, geralmente 
apresentado em forma de documento, que deve ser implementado de maneira que se alcance os objetivos esperados. Do ponto de vista de Oliveira (2007, p. 4), o plano "corresponde a um documento formal que se constitui na consolidação das informações e atividades desenvolvidas no processo de planejamento; é o limite da formalização do planejamento".

\section{○ Objetivos}

Ponto de partida do processo de planejamento Chiavenato (2000, p. 195) afirma que "a fixação dos objetivos é a primeira coisa a ser feita: saber onde se pretende chegar, para se saber exatamente como chegar lá", e complementa:

Objetivos são resultados futuros que se pretende atingir. São alvos escolhidos que se pretende alcançar dentro de um certo espaço de tempo, aplicando-se determinados recursos disponíveis ou possíveis. Assim, os objetivos são pretensões futuras que, uma vez alcançadas, deixam de ser objetivos para se tornarem realidade.

Inicialmente estabelecidos pela alta administração, Almeida (2005) afirma que é com base nos objetivos gerais que os objetivos específicos são traçados pelos níveis inferiores da organização, acarretando a existência de uma hierarquia de objetivos na qual uns predominam sobre os demais, ou seja, os maiores impõem-se aos específicos.

\section{○ Metas}

Alvos a atingir a curto prazo, as metas "são planos expressos em termos de resultados a alcançar; são a quantificação dos objetivos. Devem ser expressas com clareza, [...] devem ser mensuráveis, mutáveis e ter tempo definido" (ALMEIDA, 2005, p.6).

\section{○ Políticas e/ou diretrizes}

É por meio de documentos que as organizações formalizam suas políticas e diretrizes, que podem ser especificas ou não. De acordo com Koontz (1987, apud ALMEIDA, 2005, p. 6) "as políticas permitem decidir questões previamente, evitando repetição de análises, e ajudam a dar uma estrutura unificada a outros tipos de 
planos e delegar autoridade sem perda de controle". Chiavenato (2000) deixa claro que apesar de serem flexíveis, elas estabelecem os limites das ações dentro das organizações.

\section{○ Programas}

Atividades necessárias para que se atinja uma meta, os programas são definidos por Chiavenato (2000) como planos específicos variáveis, que podem ou não incluir um série de planos menores.

\subsubsection{Tipos de planejamento}

Existe um consenso entre os diversos autores que discorrem sobre 0 processo de planejamento, e, principalmente, em relação aos tipos de planejamento existentes. Existem três tipos principais de planejamento presente nas organizações que se distinguem de acordo com o nível hierárquico em que são aplicados. São eles: planejamento estratégico, planejamento tático ou intermediário, e o planejamento operacional.

\section{○ Planejamento estratégico}

De acordo com Chiavenato (2000, p. 198) o planejamento estratégico referese ao planejamento estabelecido pela alta administração da organização. Mais amplo que os demais níveis, é projetado a longo prazo, envolve a empresa como um todo e corresponde ao plano maior ao qual todos os membros e setores institucionais estão subordinados. Destaca-se ainda, conforme cita Almeida (2005, p. 7), o fato de ser o planejamento que "consiste no processo de decisão relativo aos objetivos da organização, às mudanças nesses objetivos, aos recursos utilizados para atingí-los e as políticas que deverão governar a aquisição, a distribuição e a utilização desses recursos", ou seja, "diz respeito tanto à formulação de objetivos quanto a seleção dos cursos de ação a serem seguidos para sua consecução, levando em consideração as condições externas e internas à empresa e sua evolução esperada" (OLIVEIRA, 2007, p. 18). 


\section{- Planejamento tático}

Em nível intermediário encontra-se o planejamento tático que, projetado a médio prazo, é definido pelos níveis organizacionais intermediários, ou seja, abrange cada departamento ou unidade organizacional, e tem como principal finalidade a utilização eficiente dos recursos disponíveis para a consecução dos objetivos já estabelecidos (CHIAVENATO, 2000, p. 198). Conforme assinala Oliveira (2007, p. 18) seu principal fim está na otimização de determinada área de resultado e não a empresa como um todo, trabalhando com a decomposição dos objetivos, estratégias e políticas previamente estabelecidos no planejamento estratégico, ou seja, é o planejamento por meio do qual as decisões estratégicas previamente estabelecidas se traduzem em planos concretos que serão posteriormente detalhados em planos operacionais (ALMEIDA, 2005, p.).

\section{- Planejamento operacional}

Por fim, tem-se o planejamento operacional por meio do qual se "decide 'o que fazer' e 'como fazer" (ALMEIDA, 2005, p. 8). Conforme afirma Chiavenato (2000, p. 199) é o planejamento quem além de ser projetado a curto prazo e definido em nível operacional, abrange as atividades especificas da organização e preocupase com o alcance das metas especificas da mesma. É também por meio dele que se tem "a formalização, principalmente através de documentos escritos, das metodologias de desenvolvimento e implantação de resultados específicos a serem alcançados pelas áreas funcionais da empresa" (OLIVEIRA, 2007, p. 19). Oliveira afirma também que:

Cada um dos planejamentos operacionais deve conter com detalhes: os recursos necessários para seu desenvolvimento e implantação; os procedimentos básicos a serem adotados; os resultados finais esperados; os prazos estabelecidos; e os responsáveis pela execução e implantação.

\subsubsection{Diferenças entre os tipos de planejamento}

Por meio da analise das características especificas dos tipos de planejamento verifica-se, portanto diversas diferenças entre os mesmos, que se destacam com relação a(o): 
- Prazo: o planejamento pode ser de longo, médio ou curto prazo;

- Amplitude: pode envolver a organização como um todo, ou determinada área de resultado, ou atividades especificas da organização;

- Risco: de acordo com sua amplitude e prazo, o risco envolvido para sua implementação pode ser maior ou menor;

- Atividades: pode relacionar-se a atividades-fim ou atividades-meio;

- Flexibilidade: sua flexibilidade pode ser maior ou menor se envolver a empresa como um todo ou apenas uma pequena parte da mesma.

\subsubsection{Etapas do planejamento}

Alguns autores divergem com relação à quantidade de etapas existentes no processo de planejamento. Jones e George (2008) afirmam que o processo de planejamento é uma atividade que possui três etapas, das quais a primeira consiste na determinação dos objetivos e missão da organização; a segunda na formulação de estratégias para que se alcance os objetivos previamente traçados; e a terceira na implementação das estratégias.

Em contrapartida, Maciel (1993) afirma que o processo de planejamento possui quatro fases distintas por meio das quais a realidade da instituição é conhecida e os objetivos da mesma são traçados. São elas:

I. Análise e reflexão: "está fase corresponde ao conhecimento da realidade, pois as decisões tomadas devem se apoiar, fundamentalmente, em um conhecimento da realidade em que se vai investir" (AREZZO apud MACIEL, 1993, p. 14). É o prévio conhecimento da realidade da instituição que determina as mudanças necessárias e permite o planejamento de ações para implementá-las. Faz necessário, portanto, a realização de um diagnóstico na instituição por meio da realização de estudo de usuários, coleta de dados da instituição, analise de gráficos, fluxogramas, organogramas e documentos normativos que revelem o atual estagio de desenvolvimento da instituição. 
II. Decisão: É nesta fase em que as decisões sobre os reais objetivos da instituição e as ações necessárias para que os mesmos sejam alcançados são definidos, o que inclui a decisão sobre as atividades e tarefas que deverão ser desenvolvidas e conseqüentemente a definição de recursos humanos, materiais e financeiros necessários para o desenvolvimento das atividades.

III. Execução das tarefas planejadas: Nesta fase as atividades são executadas e simultaneamente acompanhadas pelo responsável pelo planejamento. Esse acompanhamento permite, se necessário, possíveis correções quando as atividades não são executadas com sucesso, tendo em vista que a partir do momento em que 0 processo se inicia diversos desvios podem ser visualizados.

IV. Avaliação e controle: Nesta fase, que acontece paralela e simultaneamente a anterior, os resultados obtidos são avaliados para verificar se os mesmos foram satisfatórios e se estão de acordo com os objetivos estabelecidos. Por ser um processo constante, deve ser realizada do inicio ao fim do processo.

O processo de planejamento pode e deve, por conseguinte, ser constantemente avaliado fazendo com que muitas vezes decisões anteriormente tomadas, sejam modificadas ao longo do seu desenvolvimento. "Esse processo continuo, composto de varias etapas, funciona de forma não linear" (OLIVEIRA, 2007, p.5), portanto, conforme afirma Maciel (1993, p. 16):

Não existe rigidez nesta seqüência. Quando se está envolvido num processo de planejamento, sabe-se de antemão, que todas as ações devem ser revistas, e modificá-las não revela inconsistência do planejador, e sim a necessária flexibilidade de quem sabe a importância de idas e vindas, desde a definição dos objetivos até o teste de exeqüibilidade dos mesmos, através da organização adequada das ações, voltando-se à redefinição dos objetivos e a um novo teste de exeqüibilidade, até nos aproximarmos das decisões (mais ou menos) definitivas. 


\title{
4.3 Tipos de bibliotecas
}

\author{
Segundo Fragoso (2002, p. 124): \\ São muitas, mais invariavelmente distorcidas, as visões que se costuma ter \\ de uma biblioteca. Ora é lugar sagrado, onde se guardam objetos também \\ sagrados, para desfrute de alguns eleitos, ora, sob uma óptica menos \\ romântica, é apenas uma instituição menos burocratizada, que serve para \\ consulta e pesquisa, assim como para armazenar bolor, cupins e traças. \\ Para poucos, aqueles que a freqüentam assiduamente, ela constitui o local \\ do encontro com o prazer de ler, conhecer, informar-se.
}

Fato é que a maioria das pessoas desconhece o real papel das bibliotecas, que apesar de apresentarem certas peculiaridades de acordo com o público alvo ou acervo que disponibiliza, possuem o mesmo objetivo: reunir e organizar informações, independente do suporte, de maneira que fique acessível ao seu público.

Com o intuito de desmistificar as diferenças entre os diversos tipos de bibliotecas que conhecemos, no presente trabalho serão abordadas as características mais marcantes das Bibliotecas: Infantil, Escolar, Universitária, Nacional, Pública, Especial e Especializada.

\subsubsection{Biblioteca Infantil}

É uma biblioteca que tem as crianças como publico alvo. "Seu acervo é formado por livros de literatura infantil e infanto-juvenil, jogos e outros materiais recreativos" (BRASIL, 1999, p.17). É um ambiente que deve fazer com que as crianças entrem em contato com o universo da leitura "por meio de atividades como contar histórias, pesquisar, assistir a filmes, desenhar e, claro, manusear os livros" (MARTINEZ, 2005, p. 24), este ambiente "poderá ser enriquecido com almofadas, pequenas mesinhas e cadeiras, cuidando sempre da decoração voltada para os interesses da criança" (ANTUNES, 1989, p. 113).

Um problema freqüente nesse tipo de biblioteca é o medo que a criança estrague os livros, porém não devem ser feitas restrições quanto ao manuseio do material da biblioteca, pois "essas restrições acabam mostrando o contrário do que 
deveria ser: que a leitura é difícil, chata, porque não pode tocar no livro" (MARICATO, 2005, p. 20).

Além disso, "as regras de uma biblioteca para adultos - silêncio e imobilidade - não valem para crianças, principalmente as mais novas. O espaço deve ser convidativo e confortável, permitir que elas circulem e falem" (MARICATO, 2005, p. 25). Pois é necessário que as crianças se sintam bem nesse espaço para que dessa maneira desejem sempre voltar e façam da leitura um prazer.

\subsubsection{Biblioteca escolar}

De fundamental importância para o sistema educacional de qualquer país, tendo em vista sua localização em escolas de ensino médio e fundamental, as bibliotecas escolares apresentam diversas funções e objetivos claramente definidos que visam principalmente à educação e o incentivo a leitura daqueles que a freqüentam. De acordo com Fragoso (2002, p. 127) ela "tem funções fundamentais a desempenhar e que podem ser agrupadas em duas categorias - a educativa e a cultural" por meio das quais às habilidades dos alunos são trabalhadas de modo que eles desenvolvam capacidade de estudo independente e adquiram gosto pela leitura.

Hillesheim e Fachim (2004) vêem as bibliotecas escolares como organizações que devem atuar em conjunto com professores e alunos para que as atividades de incentivo a leitura e pesquisa sejam realizadas adequadamente no ambiente escolar. Eles afirmam ainda que:

\footnotetext{
Uma biblioteca bem adaptada à comunidade escolar assumindo suas funções, disponibilizando um ambiente carregado de motivações é o local, por excelência, onde a criança aprende a gostar de ler, a se interessar pela leitura e pelo livro, ou por qualquer coisa que represente uma interpretação, uma associação, uma historia" (HILLSHEIM; FACHIM, 2004, p. 37).
}

Além disso, conforme cita Cerdeira (1977) a biblioteca escolar deve por meio das atividades oferecidas, motivar os alunos de modo que eles busquem continuamente o conhecimento, mesmo após ter cessado seu vinculo com a escola.

Esses fatores, usuários, localização e atividades desenvolvidas, levam a crer que o acervo da biblioteca escolar além de conter uma coleção básica, e que atenda 
as necessidades do seu público-alvo, deverá voltar-se as ações educativas desenvolvidas no ambiente escolar, pois a biblioteca "passou a ser concebida como um novo tipo de centro de recursos educativos no qual a ênfase não é apenas colocada na leitura, mas, igualmente, em ouvir e observar materiais que compreendem slides, transparências, filmes, diagramas, etc." (CERDEIRA, 1977, p.36), devendo portanto, possuir em sua colação todo e qualquer tipo de documento passível de serem usados em atividades educativas.

Percebe-se assim que de acordo com suas atribuições, toda biblioteca escolar deve, portanto, participar ativamente do processo educacional planejando atividades curriculares; fazer da biblioteca um local atrativo; estimular os alunos por meio de atividades como à hora do conto; estimular os educadores a utilizarem a biblioteca como espaço pedagógico; oferecer elementos que incentivem a leitura; etc., diferenciando-se assim das demais bibliotecas que conhecemos (FRAGOSO, 2002).

\subsubsection{Biblioteca universitária}

Com objetivo principal de dar subsídios às pesquisas realizadas no âmbito acadêmico e por ser considerada por muitos um instrumento essencial no processo de ensino-aprendizagem dos estudantes universitários, as bibliotecas universitárias "além de possibilitarem acesso à informação, têm um papel de maior relevância, enquanto favorecem o desenvolvimento de potenciais, capacitando pessoas a formarem suas próprias idéias e a tomarem suas próprias decisões" (FERREIRA, 1980, p. 5).

Essa biblioteca funciona, portanto como um órgão de apoio informacional às atividades de ensino, pesquisa e extensão desenvolvidas no âmbito da universidade e de acordo com Lück et. al. (2000, p.2) "pode ser entendida como a instância que possibilita à universidade atender às necessidades de um grupo social ou da sociedade em geral, através do seu patrimônio informacional e do exercício de uma função educativa, ao orientar os usuários na utilização da informação". Domingo (2005, p. 47-46) destaca ainda que: 
En primer lugar, las bibliotecas siguen siendo la estructura de apoyo esencial para que las universidades cumplan sus objetivos de formación e investigación. Es su función tradicional y debe seguir siendo su misión prioritaria. Sin embargo, para responder adecuadamente a estos objetivos, las bibliotecas universitarias tienen que asumir los cambios que afectan tanto a las universidades como a la sociedad e incorporarlos a su desarrollo, a sus estrategias de gestión y a sus servicios.

A biblioteca universitária deve, portanto acompanhar as mudanças que ocorrem dentro da universidade e ao visar o atendimento as necessidades informacionais de seus usuários - principalmente alunos de cursos de graduação, pós-graduação e professores - deve manter seu acervo bibliográfico atualizado, tendo em vista a produção bibliográfica em constante expansão.

De acordo com Oliveira, Botello e Faria Junior (2008) por se encontrar dentro da universidade o acervo dessa biblioteca é composto por literatura branca (publicações comerciais) e literatura cinzenta (publicações não comerciais) dos quais fazem parte livros, periódicos, trabalhos de conclusão de curso, anais de congressos, dissertações e teses. Esse acervo poderá ainda ser centralizado se a universidade possuir apenas uma biblioteca para atender a todos os cursos, ou descentralizado se cada curso possuir sua biblioteca.

Eles afirmam ainda que na busca constante pela satisfação dos usuários, as bibliotecas universitárias disponibilizam diversos serviços que vão desde empréstimos e reservas de livros, até normalização bibliográfica de trabalhos acadêmicos, treinamento de usuários, acesso a base de dados e serviços de comutação bibliográfica que visa à obtenção de documentos em outras bibliotecas nacionais ou até mesmo internacionais.

Sendo um organismo dentro de um maior o que diferencia a biblioteca universitária das demais que conhecemos, é, portanto o seu caráter acadêmico e o apoio oferecido aos professores e alunos universitários em suas pesquisas.

\subsubsection{Biblioteca nacional}

Pode-se dizer que:

A Biblioteca Nacional é, em princípio, sinônimo de memória documental da cultura de um país; é, no seu sentido mais alto, museu de toda a sua produção bibliográfica, nos mais diversos campos culturais, através da sua 
história. Seu acervo, constituído dentro desta idéia diretriz, tem por objetivo oferecer, no futuro, a documentação suficiente ao juízo crítico da produção intelectual do passado, e, no presente, os necessários elementos de informação, que condicionam um consciente e harmonioso desenvolvimento cultural" (MONTE-MÓR, 1972, p. 15).

Ou seja, as bibliotecas nacionais funcionam como guardiãs da produção intelectual do país, assumindo "o papel institucional de preservação da memória do conhecimento" (ANDRADE, 2009, p. 3).

Para cumprir sua função, existe a Lei do Depósito Legal que exige que a biblioteca nacional receba pelo menos um exemplar "de toda publicação de qualquer espécie, reproduzida em qualquer suporte, por qualquer processo, e colocada à disposição do público" (MANAGAZ, 1987, p. 36).

Muitas das funções que as bibliotecas nacionais desempenham hoje foram recomendadas após o III Congresso Internacional de Bibliotecas, no Colóquio das Bibliotecas Nacionais da Europa. Esse Congresso ocorreu em Bruxelas, em 1955, e teve como discussão a necessidade de uma biblioteca central responsável pela conservação e uniformização da produção bibliográfica do país. E no Colóquio que ocorreu logo depois foram estabelecidas recomendações com o intuito de nortear as bibliotecas nacionais. Recomendações como, responsabilidade de adquirir e conservar a produção nacional impressa e as publicações estrangeiras necessárias ao país; adoção de regras comuns de catalogação; produção das bibliografias nacionais correntes através do Boletim Bibliográfico; dentre outras, orientaram diversos países, inclusive o Brasil (ANDRADE, 2009).

Porém é importante notar que o conceito de biblioteca tem evoluído e com isso as bibliotecas nacionais devem "reexaminar a situação que ocupam, o papel que desempenham na coletividade em que se localizam e a qual servem, e, muito especialmente, a posição em que se encontram nos sistemas de bibliotecas, ou nos sistemas de informação bibliográfica do país" (MONTE-MÓR, 1972, p. 15).

\subsubsection{Biblioteca pública}

A biblioteca pública possui um conceito mais amplo que as demais bibliotecas. "O que melhor a caracteriza é ela ser plenamente aberta a toda a 
população local; é ser comum a todos; é destinar-se não a determinada comunidade (como é a biblioteca escolar, a universitária, a especial, a especializada e a infantil), mas a toda a coletividade" (BRASIL, 1999, p.18), independente de idade, classe social, cor, sexo, religião, pois seus serviços estão baseados na igualdade de acesso para todos. Seu acervo deverá possuir "todos os gêneros de obras que sejam do interesse da coletividade a que pertence. [...] além da literatura em geral, as informações básicas sobre a organização do governo e sobre serviços públicos em geral, tais como produtividade, saúde pública, fontes de emprego" (BRASIL, 1999, p.19), também deverão estar disponíveis.

É um tipo de biblioteca que cada segmento da sociedade tem uma visão em relação a sua função. Para a indústria editorial o seu objetivo é a formação de um público leitor; para os educadores deve ser o alicerce do processo ensinoaprendizagem; para os intelectuais deve ser um espaço rico em literatura de ficção; e na visão do trabalhador comum a biblioteca não é um ambiente que ajuda a resolver os problemas do dia-a-dia (SUAIDEN, 2000).

Segundo a UNESCO, no Manifesto sobre Bibliotecas Públicas, de 1994, as missões-chave da biblioteca pública são as seguintes:

- Criar e fortalecer os hábitos de leitura nas crianças, desde a primeira infância;

- Apoiar a educação individual e a auto-formação, assim como a educação formal a todos os níveis;

- Assegurar a cada pessoa os meios para evoluir de forma criativa;

- Estimular a imaginação e criatividade das crianças e dos jovens;

- Promover o conhecimento sobre a herança cultural, o apreço pelas artes e pelas realizações e inovações científicas;

- Possibilitar o acesso a todas as formas de expressão cultural das artes do espectáculo;

- Fomentar o diálogo inter-cultural e a diversidade cultural;

- Apoiar a tradição oral;

- Assegurar o acesso dos cidadãos a todos os tipos de informação da comunidade local;

- Proporcionar serviços de informação adequados às empresas locais, associações e grupos de interesse; 
- Facilitar o desenvolvimento da capacidade de utilizar a informação e a informática;

- Apoiar, participar e, se necessário, criar programas e actividades de alfabetização para os diferentes grupos etários.

Analisando o Manifesto da UNESCO é notável que a biblioteca pública tem como base a igualdade de acesso para todos e assume assim um papel de "vital importância na medida em que pode se tornar o grande centro disseminador da informação, atuando principalmente para diminuir as desigualdades existentes na socialmente injusta sociedade brasileira" (SUAIDEN, 2000, p. 52).

\subsubsection{Biblioteca especializada}

Assim como os demais tipos de bibliotecas existentes, a biblioteca especializada tem como principal objetivo atender as necessidades informacionais de seus usuários, se diferenciando das outras, devido algumas características peculiares que apresenta.

Conforme cita Salasário (2000, p.105) "existem três princípios teóricos quanto ao conceito de biblioteca especializada: os que tratam do acervo que a biblioteca possui e disponibiliza; os que falam do tipo de usuário que a freqüenta; os que colocam o tipo de acervo associado ao tipo de usuário", sendo esses os principais aspectos que a diferencia das demais bibliotecas que conhecemos anteriormente.

De acordo com Araújo, Silva e Andrade (2004, p. 3) em se tratando do acervo, levando em consideração que as entidades das quais as bibliotecas especializadas fazem parte - bancos, companhias de seguros, museus, hospitais, entidades beneficentes, etc. - "possuem metas especificas e isto se reflete na orientação das respectivas bibliotecas", a biblioteca especializada se dedica quase que exclusivamente a publicações sobre um assunto especifico, ou seja, que se restringem a uma só área, concentrando sua atenção a um grupo de temas que se relacionam intimamente entre si.

Em relação ao usuário que freqüenta este tipo de biblioteca, "geralmente funcionários, pesquisadores, técnicos, cientistas, etc." (MIRANDA, 2007, p. 88), além de possuírem necessidades informacionais especificas, as mesmas estão 
"relacionadas diretamente com sua carreira ou com o serviço que prestam a sociedade" (ARAUJO, SILVA, ANDRADE, 2004, p. 4).

Miranda (2007, p. 88) deixa claro que além desses motivos básicos, a biblioteca especializada possui outras características que a difere das demais, dentre os quais se destaca o fato de possuir usuários exigentes e com alto nível de formação, acervo composto por uma diversidade de suportes informacionais e bibliotecários com grande conhecimento na área a que se destina a coleção.

"Desta forma, unindo-se acervo e usuário tem-se o conceito de biblioteca especializada, ou seja, uma unidade de informação com acervo especializado destinado à satisfação das necessidades informacionais de um publico especifico" (SALASÁRIO, 2000, p. 108).

\subsubsection{Biblioteca Especial}

"A diferença entre biblioteca especializada e a especial é que esta não se distingue pelo assunto, ou pelo tipo de acervo, mas pelo seu público (BRASIL, 1999, p.18). É uma biblioteca que está "fundamentalmente relacionada com pessoas com necessidades especiais, como por exemplo, culturais, lingüísticas, pessoas com deficiências físicas, mentais, auditivas, invisuais e pessoas hospitalizadas ou reclusas" (LOUSADA, 2006, p.1). Ou seja, "a biblioteca especial se dedica a atender a um tipo especial de usuário" (BRASIL, 1999, p.18). E tem como objetivo assegurar, sem restrições, que esses usuários, mesmo com algumas 'limitações', tenham acesso a informação.

Embora a Biblioteca Especial atenda a diversos tipos de usuários que possuam algum tipo de 'limitação', o foco desse trabalho será a biblioteca especial para pessoas enfermas, ou seja, que possui como público alvo: os doentes hospitalizados e a sua família.

De acordo com Lousada (2006, p. 6) os objetivos da biblioteca especial para doentes são:

contribuir para o bem-estar e para a cura dos doentes, obtendo, organizando, mantendo e fornecendo documentos de biblioteca e serviços que, de acordo com as necessidades dos doentes, poderão ser um meio de diversão, de terapia, de cultura e, eventualmente, de educação. Sempre que 
necessário, devem oferecer informações médicas acerca de doenças específicas ou de outros problemas ligados à saúde, tais como a etiologia, o diagnóstico, o prognóstico e o tratamento.

Essa biblioteca visa à melhoria de pacientes por meio do acesso a leitura, funcionando assim como agente terapêutico. Segundo Seitz (2006, p. 84.):

quando o paciente lê, cria um universo independente, como se mergulhasse em um mundo novo de aventuras e fantasias. Essa viagem provoca um desligamento dos problemas, das angústias, do medo e das incertezas, proporcionando um alívio das tensões emocionais, contribuindo para o bemestar mental do paciente.

Conforme Lousada (2006, p. 7), a política de seleção do acervo dessas bibliotecas, assim como acontece em todas as outras bibliotecas, "deverão considerar as necessidades e gostos da clientela visada". 


\title{
5 Estudo de Caso: Associação Brasileira de Assistência as Pessoas com Câncer - ABRAPEC
}

As organizações não-governamentais, organizações do setor público nãogovernamental ou ONGs, como são comumente conhecidas, designam entidades executoras de projetos humanitários ou de interesse público, que apresentam "uma natureza instável [...] uma vez que sobrevivem por meio de projetos financiados por organizações internacionais, cooperação internacional entre países ou pelo próprio Estado" (Pinto, 1996, p.655).

Tenório (2005, p.7) afirma que apesar de não apresentarem ligação direta com o Estado, essas organizações "se revestem de caráter público na medida em que se dedicam a causas e problemas sociais, e em que, apesar de serem sociedades civis privadas, não tem como objetivo o lucro, e sim o atendimento das necessidades da sociedade".

De acordo com os membros e as causas que defendem, Pinto (2006, p. 657) classifica essas instituições em dois grupos:

\begin{abstract}
as organizações que defendem a causa de seus membros, formadas por negros contra o racismo, ou por mulheres contra o sexismo, ou por gays contra o preconceito em relação à escolha sexual; as que defendem a causa de outros, tais como meninos de rua, sem-teto, drogados, vítimas de abusos contra os direitos humanos, vítimas de abuso sexual, excluídos da cidadania por pobreza ou ignorância etc.
\end{abstract}

Dentre as instituições que defendem as causas dos outros encontra-se a Associação Brasileira de Assistência as Pessoas com Câncer - ABRAPEC, que é uma instituição voltada ao atendimento de pessoas carentes, abaladas emocionalmente pela doença e que não tem condições de arcar com as despesas do tratamento.

Com o intuito de se ter uma visão clara sobre as atividades que são desempenhadas no âmbito dessa organização, realizou-se um diagnóstico na instituição para conhecer as questões relativas aos serviços prestados a comunidade e a qualidade dos mesmos, pois isso dará, por meio da identificação da dos pontos fortes e fracos da instituição, subsídios para que novas ações sejam desenvolvidas com e para os pacientes que freqüentam a instituição. 


\subsection{Objetivos}

Estudar e verificar por meio de um levantamento de dados a realidade da instituição, os serviços que ela oferece e os pacientes que fazem uso desses serviços.

\subsection{Estudos do ambiente}

A ABRAPEC, presente em diversos estados do Brasil, dispõe em uma de suas filiais, localizada em Taguatinga-DF, de uma biblioteca que atende tanto aos pacientes como funcionários desta unidade.

A unidade de Taguatinga-DF e os serviços que ela oferece que são objetos principais deste estudo, inserem-se em um ambiente que envolve a sede da ABRAPEC, a unidade de Taguatinga e a Biblioteca desta unidade conforme é apresentado na Figura 1:

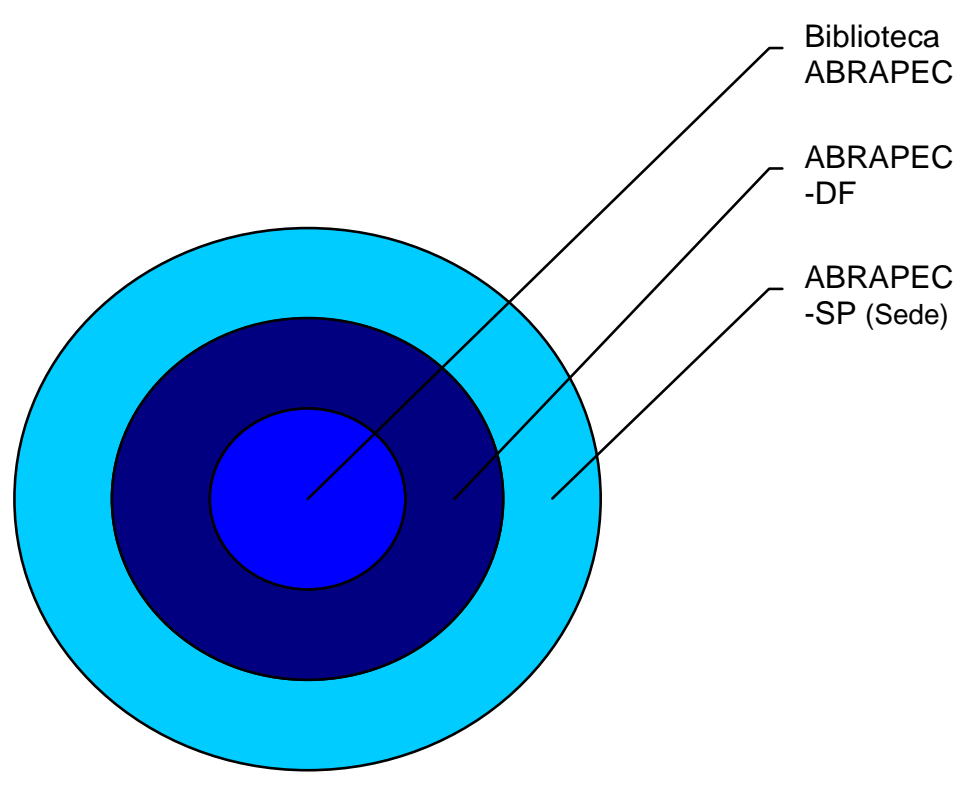

Figura 1 - Diagrama sistêmico da ABRAPEC /DF 


\subsubsection{Associação Brasileira de Assistência as Pessoas com Câncer - ABRAPEC}

A Associação Brasileira de Assistência as Pessoas com Câncer - ABRAPEC, representada em vários estados do Brasil por suas filiais, assiste a pessoas portadoras de câncer que não possuem condições financeiras para arcar com todas as despesas do tratamento, que além de custar caro, se mostra muito doloroso para os pacientes e familiares.

Fundada de acordo com a Lei Federal no 9.790/99 em São Paulo (SP), no ano de 2002, por Arnaldo Braz, empresário e radialista, a ABRAPEC é uma organização não-governamental e sem fins lucrativos, que tem como missão prestar apoio biopsicossocial às pessoas adultas e idosas com câncer, bem como a seus familiares, em vulnerabilidade social, proporcionando uma melhor qualidade de vida para o enfrentamento da doença.

Seu objetivo principal é suprir as necessidades básicas dos usuários que não possuem condições financeiras e muitas vezes necessitam de medicamentos específicos para o tratamento do câncer, materiais para curativos, cadeira de roda/banho - por se encontrarem em um estado avançado da doença, alimentação adequada, suplementos alimentares, fraldas geriátricas, exames laboratoriais, vale transporte para poderem freqüentar as atividades oferecidas pela ABRAPEC, etc. Além disso, a Instituição prioriza manter os pacientes informados sobre os direitos das pessoas acometidas de câncer e o trabalho do estado emocional e da autoestima por meio de atividades como a psicoterapia e outras terapias complementares.

Em seu Estatuto ficam claros os objetivos da Associação, pois consta que a ela buscará sempre de forma gratuita, a promoção da assistência social, visando lutar, zelar e primar pelo estabelecimento e desempenho de política filantrópica ligada a pessoas com câncer em geral e sua família, desde que sob a condição formal de carente economicamente ou de baixa.

Atualmente existem, além da Sede em São Paulo (SP), 6 unidades, que apesar de serem independentes financeiramente da Sede, são subordinadas a ela, devendo prestar contas do andamento das suas atividades, e seguir as normas do Estatuto da Associação. Constantemente a instituição também realiza reuniões entre 
as sucursais da ABRAPEC para que elas tomem conhecimentos de possíveis mudanças na instituição e de novas atividades que poderão ser oferecidas aos pacientes. Essas unidades estão localizadas em: Jundiaí/SP, Ribeirão Preto/SP, Campo Grande/MS, Porto Alegre/RS, Taguatinga/DF e Rio de Janeiro/RJ.

O organograma abaixo permite a visualização da atual estrutura organizacional da Associação e subordinação das sucursais a Sede:

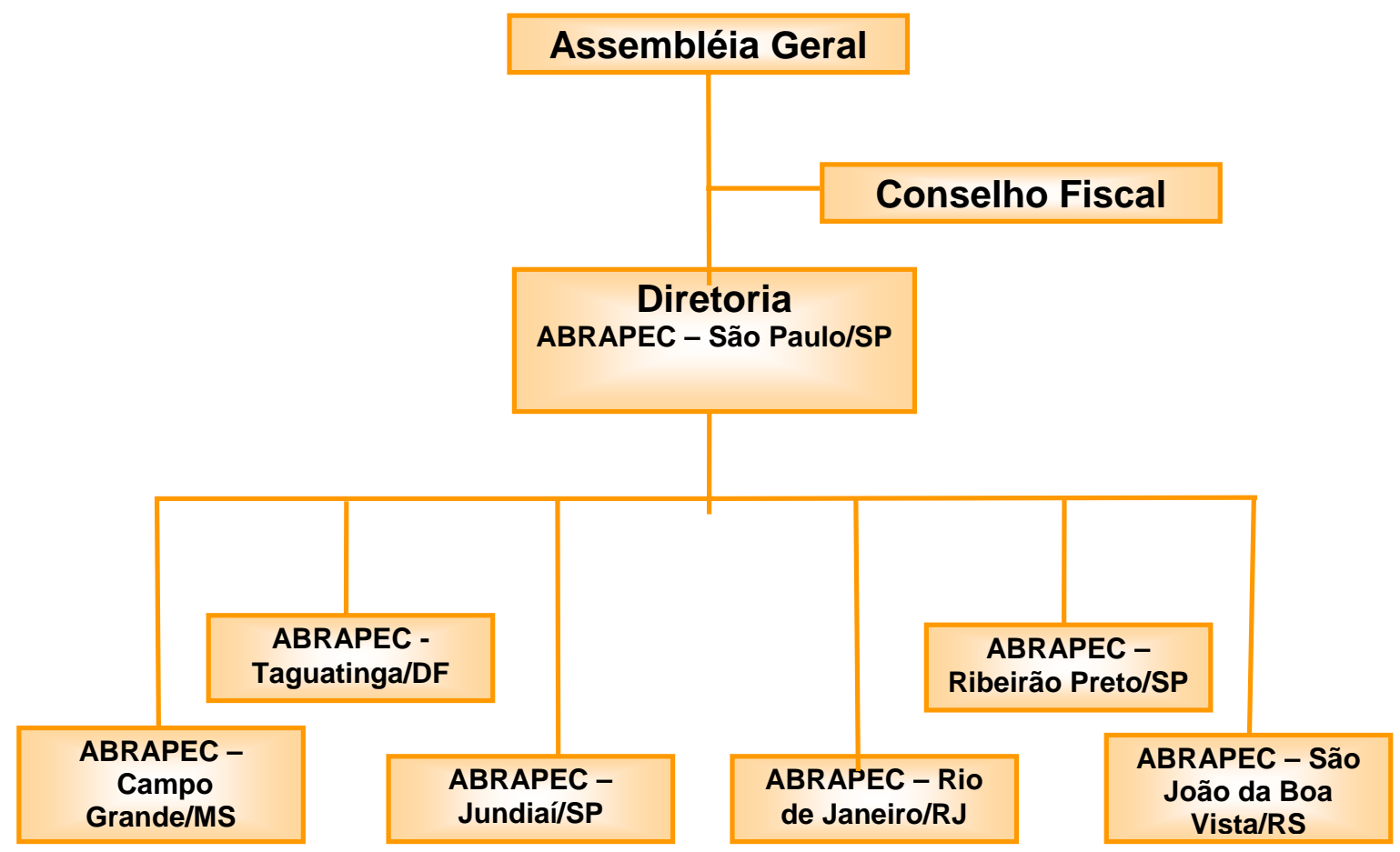

Figura 2 - Estrutura Organizacional da ABRAPEC

\subsubsection{ABRAPEC Taguatinga-DF}

○ Histórico, criação e institucionalização

Fundada em 10 de outubro de 2002 sob o CNPJ 05.116.931/0004-16 a unidade de Taguatinga/DF, assim como as demais, busca por meio das atividades oferecidas dar apoio aos pacientes e familiares que se encontram vulneráveis devido aos efeitos apresentados pela enfermidade.

Não existem muitos dados sobre a história da unidade, porém a analise do Estatuto juntamente com informações oferecidas pela Assistente Social permitiram a 
elaboração de um organograma e compreensão da estrutura administrativa da mesma.

A estrutura organizacional da instituição, subordinada a sede, conta atualmente com um setor de captação de recursos, ou telemarketing como é comumente conhecido, com uma coordenação geral, que atua na gestão dos serviços como um todo, e por fim, com um setor de serviços fins que atua no gerenciamento das atividades oferecidas aos pacientes e um setor de serviços meios, responsável pelo apoio administrativo como um todo, o que inclui os serviços de limpeza, recepção, entre outros, conforme apresentado na Figura 3: 


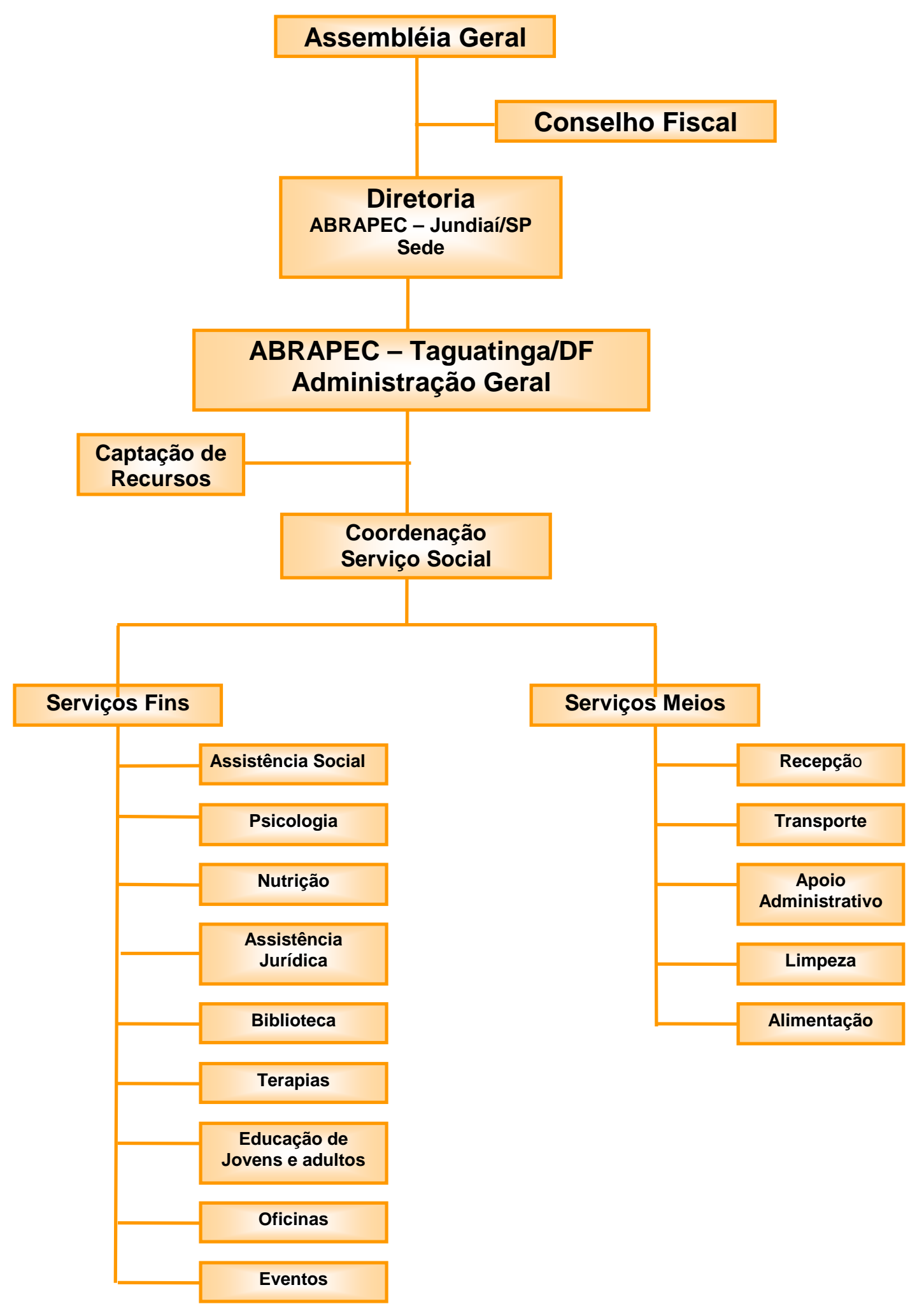

Figura 3 - Estrutura organizacional da ABRAPEC/DF 


\section{○ Usuários e demanda}

Desde o seu surgimento, em 2002, a ABRAPEC Taguatinga atendeu à cerca de 582 pacientes. Atualmente a unidade possui aproximadamente 120 pacientes ativos. Em sua maioria, eles são encaminhados pelo Hospital de Base de Brasília, pelo Hospital Universitário-HUB e/ou pelo Hospital Regional de Taguatinga-HRT.

Para serem incluídos no atendimento os pacientes encaminhados passam por uma entrevista socioeconômica com a Assistente Social, que traça o perfil do paciente e analisa a possibilidade dele freqüentar as atividades oferecidas pela instituição e suas reais necessidades quanto ao recebimento de medicamentos, cesta básica e materiais como fraldas geriátricas, roupas, calçados, etc.

Neste momento, segundo dados de 2009 da ABRAPEC/DF, eles provem de diversas cidades satélites como Ceilândia (28\%), Samambaia (13\%), Recanto das Emas (11\%) e de regiões do entorno como Águas Lindas (11\%) e Santo Antônio do Descoberto (4\%), o que pode ser observado na Figura 4:

\section{Procedência dos Pacientes}
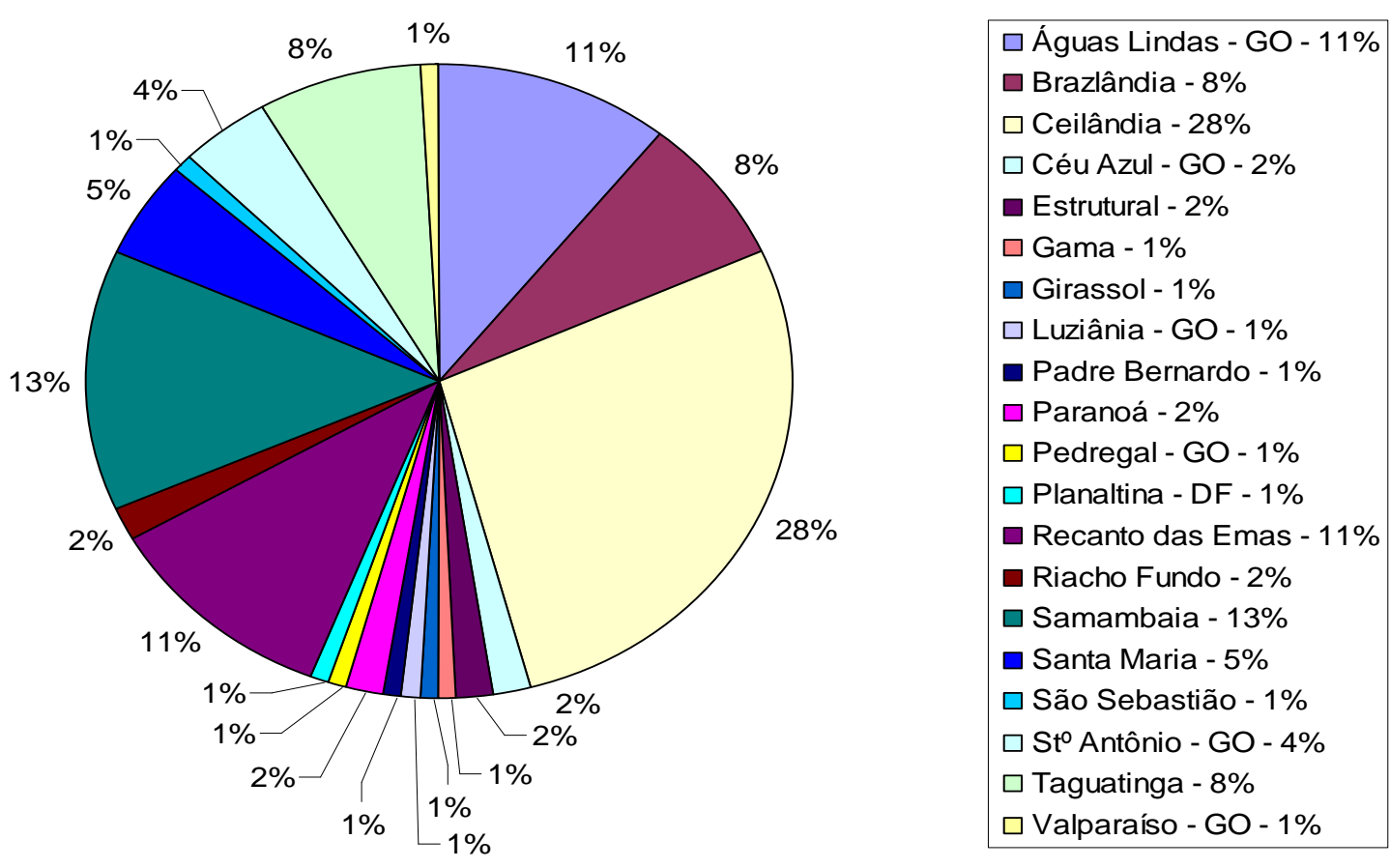

Figura 4 - Procedência dos Pacientes 
Em relação ao sexo a maioria dos pacientes é do sexo feminino, dos 120 pacientes que freqüentam a ABRAPEC atualmente, apenas 27 (23\%) são homens enquanto 93 (77\%) são mulheres. De acordo com a Figura 5:

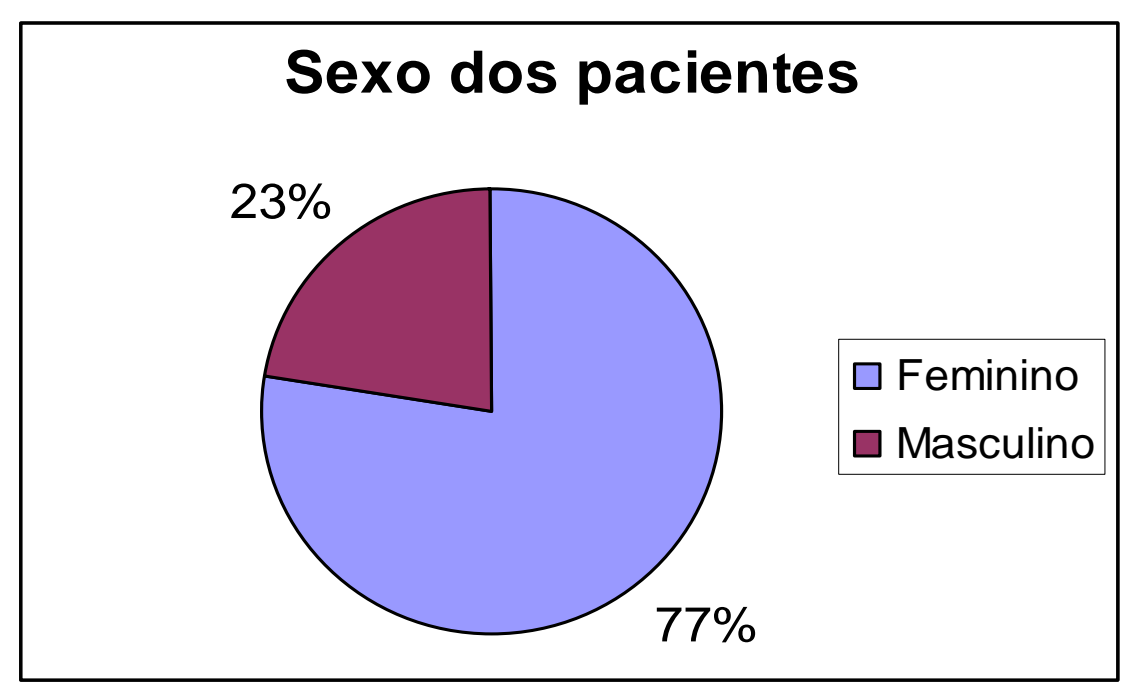

Figura 5 - Sexo dos Pacientes

Conforme a Figura 6, a maioria dos pacientes possui mais de 50 anos de idade, $39(32 \%)$ se enquadram na faixa que vai de 51 a 60 anos, 14 (12\%) de 61 a 70 , e $4(4 \%)$ tem mais de 70 anos. Porém é possível notar também que 11 (10\%) deles possuem menos de 30 anos e 17 (14\%) tem entre 31 e 40 anos.

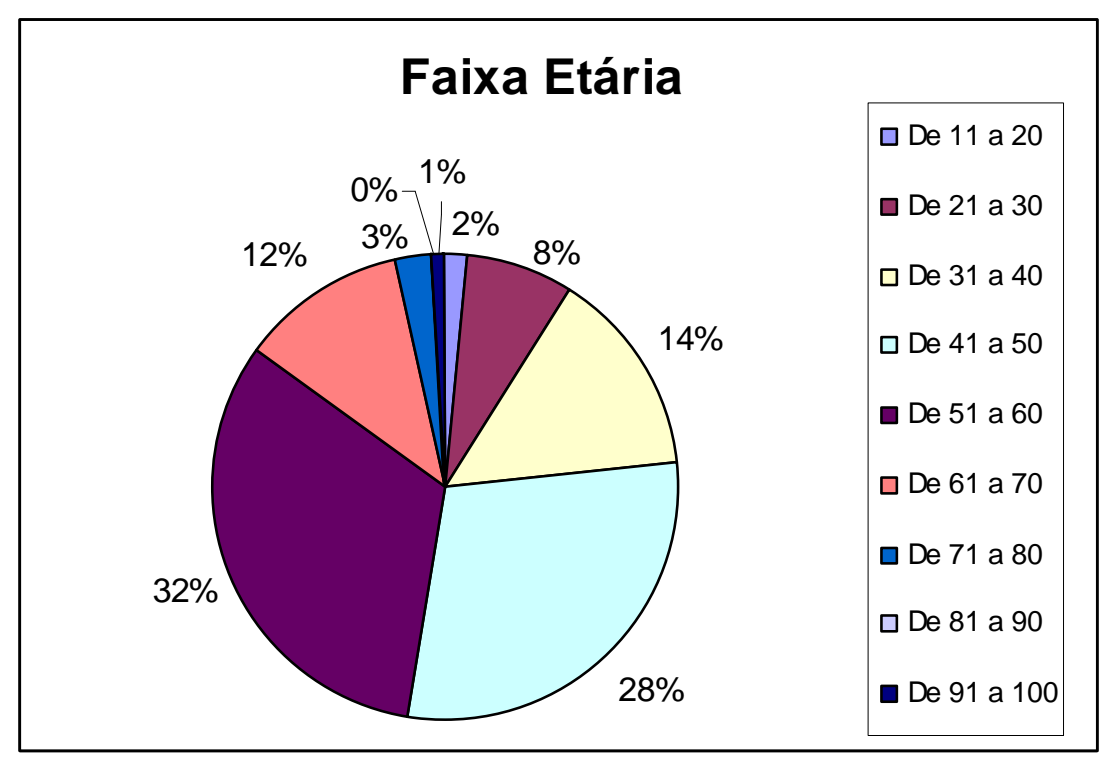

Figura 6 - Faixa etária 
A instituição atende pacientes que possuem os mais variados tipos de câncer. Na Figura 7 percebe-se a maior freqüência do câncer de mama (33\%), seguido do câncer de útero (18\%). Visto que esses tipos de cânceres acometem somente mulheres é possível notar que esses dados são compatíveis com a Figura 3, que ilustra que $77 \%$ dos usuários são do sexo feminino.

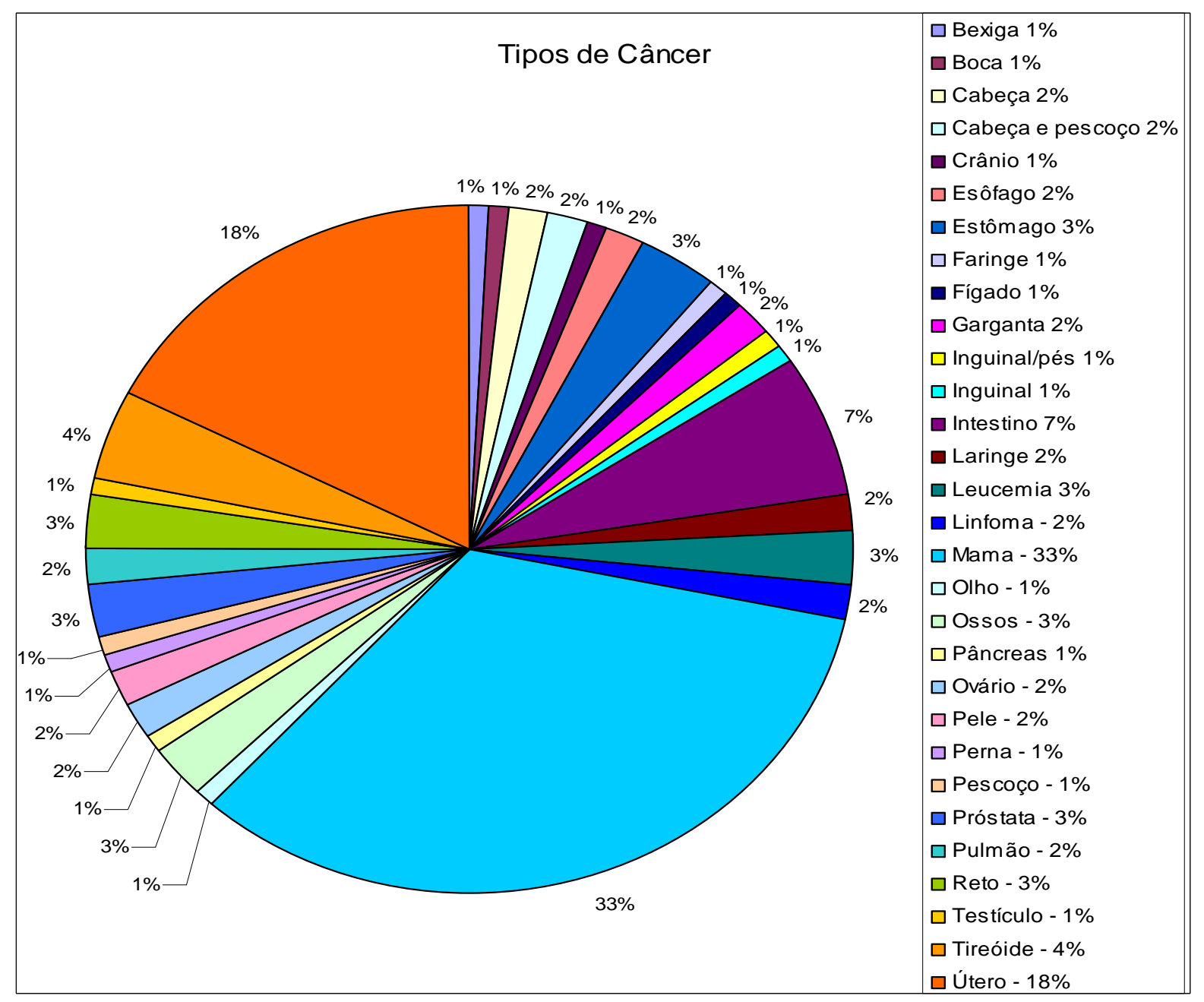

Figura 7 - Tipos de Câncer

○ Recursos Organizacionais Existentes

\section{Recursos humanos}

Atualmente a instituição conta com uma equipe de trabalho que inclui ao todo 8 funcionários, dentre os quais: um gerente operacional, uma assistente social, uma auxiliar de escritório, uma recepcionista, um motorista, um motoboy, duas 
psicólogas e uma equipe de telemarketing composta por cerca de 15 funcionários. Esses funcionários, por serem remunerados, são pagos com recursos financeiros provenientes das doações e parcerias. Além disso, a instituição conta com aproximadamente 19 voluntários, que atuam em diversas áreas e tornam possível que muitas atividades sejam realizadas diariamente.

\section{Parcerias}

Dentre as parcerias que a ABRAPEC possui com outras instituições destacam-se a parceria com: o Hospital de Base, o Hospital Universitário-HUB e o Hospital Regional de Taguatinga-HRT, que encaminham para a instituição pacientes portadores de câncer, que se encontram em vulnerabilidade social. Além disso, conta também com a ajuda da Casa do Ceará, que mensalmente disponibiliza para a ABRAPEC duas consultas gratuitas, normalmente, com oftalmologista, neurologista e/ou psiquiatra.

Outra parceria importante é realizada com a Faculdade de Ciências Sociais e Tecnológicas - FACITEC, que disponibiliza bolsa integral de curso superior para os alunos do projeto "Educação de Jovens e adultos - EJA" da ABRAPEC que passarem no vestibular.

\section{Instalações Físicas e Recursos Materiais}

Atualmente a ABRAPEC-DF funciona em uma residência, localizada em Taguatinga Norte e conta ainda com uma sala comercial, também em Taguatinga, na qual funciona o serviço de Telemarketing. Ambas são alugadas, portanto, pagas com recursos financeiros obtidos por meio das doações.

Todas as atividades realizadas com os pacientes são desempenhadas nessa casa, que possui aproximadamente 11 ambientes diferentes, e inclui salas de atendimento individual, de realização de atividades em grupo, sala de espera, cozinha, o que pode parcialmente ser observado nas Fotos 1 a 4: 


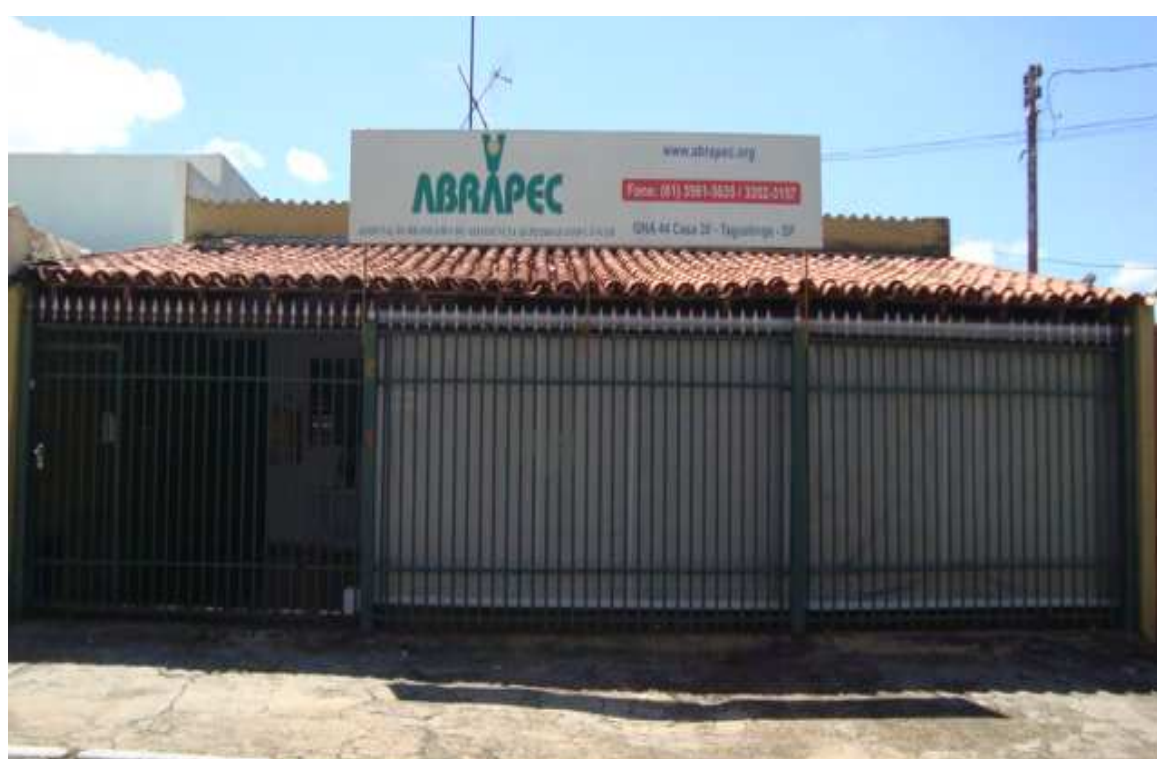

Foto 1 - Fachada da ABRAPEC/DF

Ao chegarem a ABRAPEC voluntários, pacientes, familiares e visitantes são recebidos na recepção da instituição (Foto 2), na qual se encontra também a atual "biblioteca" e trabalhos manuais feitos pelos pacientes nas oficinas oferecidas.

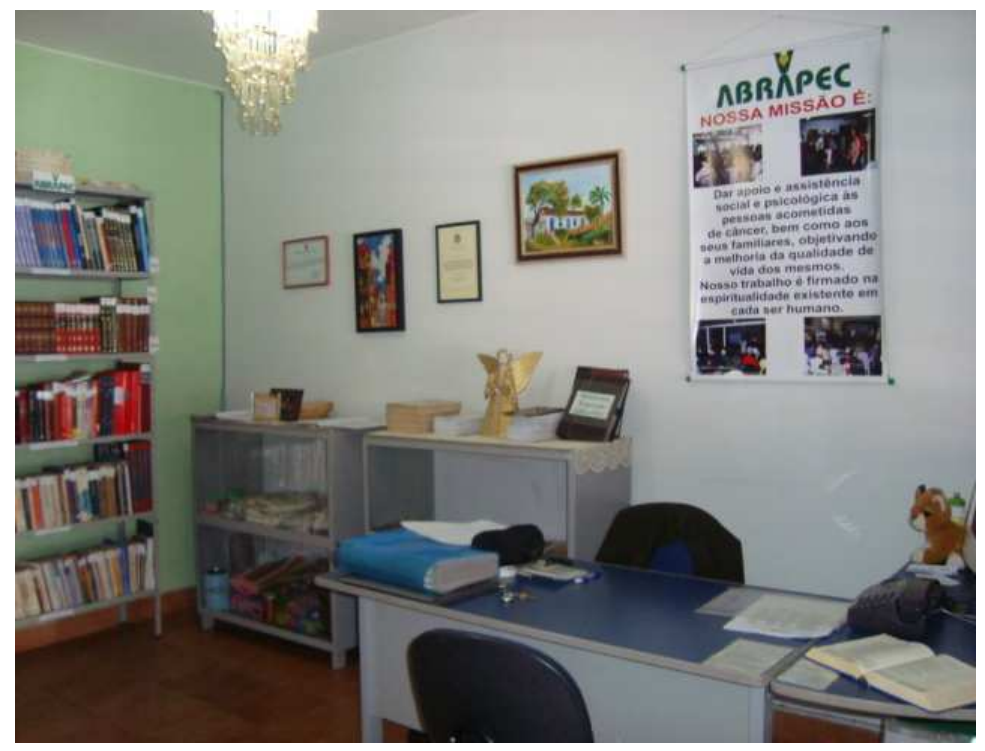

Foto 2 - Recepção da ABRAPEC/DF

Aos pacientes - durante o intervalo de realização das atividades - são oferecidos lanches preparados na cozinha da instituição (Foto 3), que atualmente se encontra totalmente equipada com os objetos necessários para o armazenamento e preparação dos alimentos. Todos os equipamentos (geladeira, fogão, liquidificador, batedeira, etc.) foram obtidos por meio de doações. 


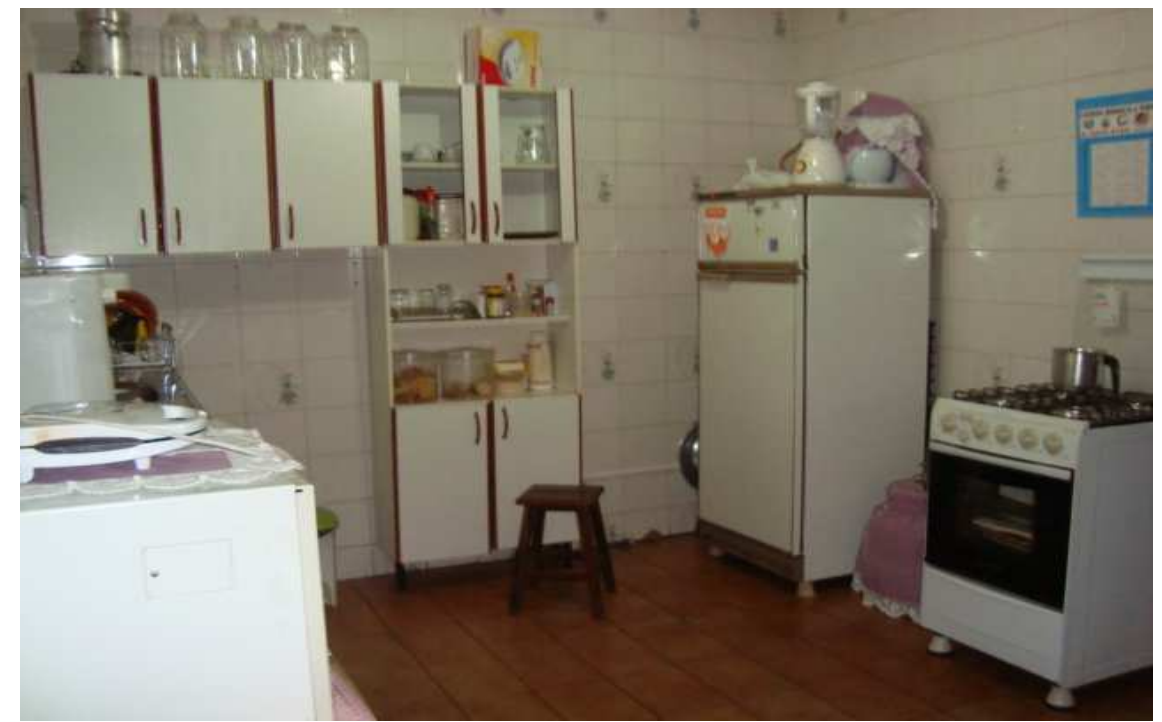

Foto 3 - Cozinha da ABRAPEC/DF

A instituição conta ainda com uma sala de espera (Foto 4) para os pacientes que aguardam pelo atendimento com a psicóloga ou massagem terapêutica.

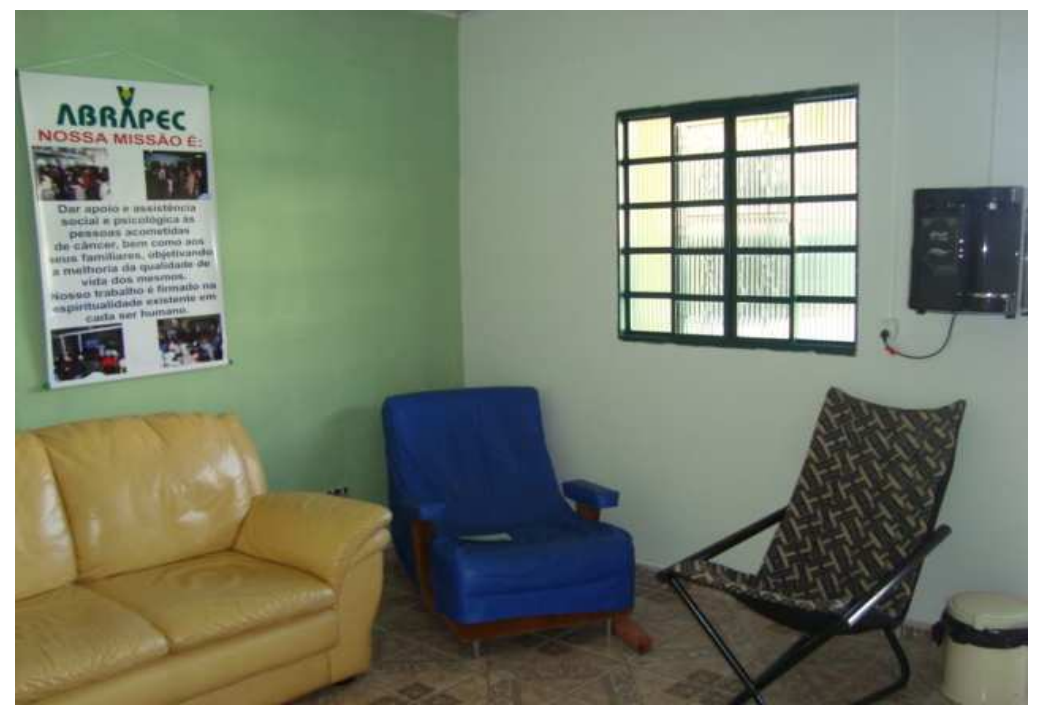

Foto 4 - Sala de espera

\section{Recursos financeiros}

Todos os recursos financeiros da ABRAPEC são obtidos por meio de doações. Para isso eles contam com uma equipe de telemarketing que mantém contato com os doadores constantemente. 


\section{- Serviços Oferecidos}

Para alcançar seus objetivos a ABRAPEC/DF oferece e realiza diversas atividades com os pacientes e seus familiares. Dentre os serviços oferecidos pela instituição destacam-se:

\section{Serviço Social}

Nesse Serviço é realizada uma triagem com os pacientes encaminhados a ABRAPEC para saber suas reais necessidades físicas, psicológicas, financeiras e materiais. É por meio dele que a Assistente Social, juntamente com os outros membros da equipe da ABRAPEC, avaliam e trabalham a sensibilidade e os sentimentos - medo, angustia, desespero e até mesmo revolta - que cercam os pacientes encaminhados à instituição. $O$ atendimento pode ser a nível individual, na sala da Assistente Social (Foto 5) ou coletivo, por meio das atividades realizadas.

Por meio da atuação do assistente social avalia-se, portanto os fatores sociais, culturais, políticos e econômicos que permeiam a realidade dos pacientes e também de seus familiares, para que posteriormente, se tenha informações suficientes sobre os reais fatores que podem intervir no processo saúde/doença do paciente, tanto a nível individual quanto coletivo.

Compete ainda ao serviço social fornecer informações aos pacientes sobre as atividades oferecidas pela instituição; o planejamento de novas atividades a serem realizadas no âmbito da associação; o acompanhamento dos pacientes bem como a evolução de seu tratamento; e o encaminhamento de recursos que possam auxiliar o usuário e a sua família na continuidade do tratamento. 


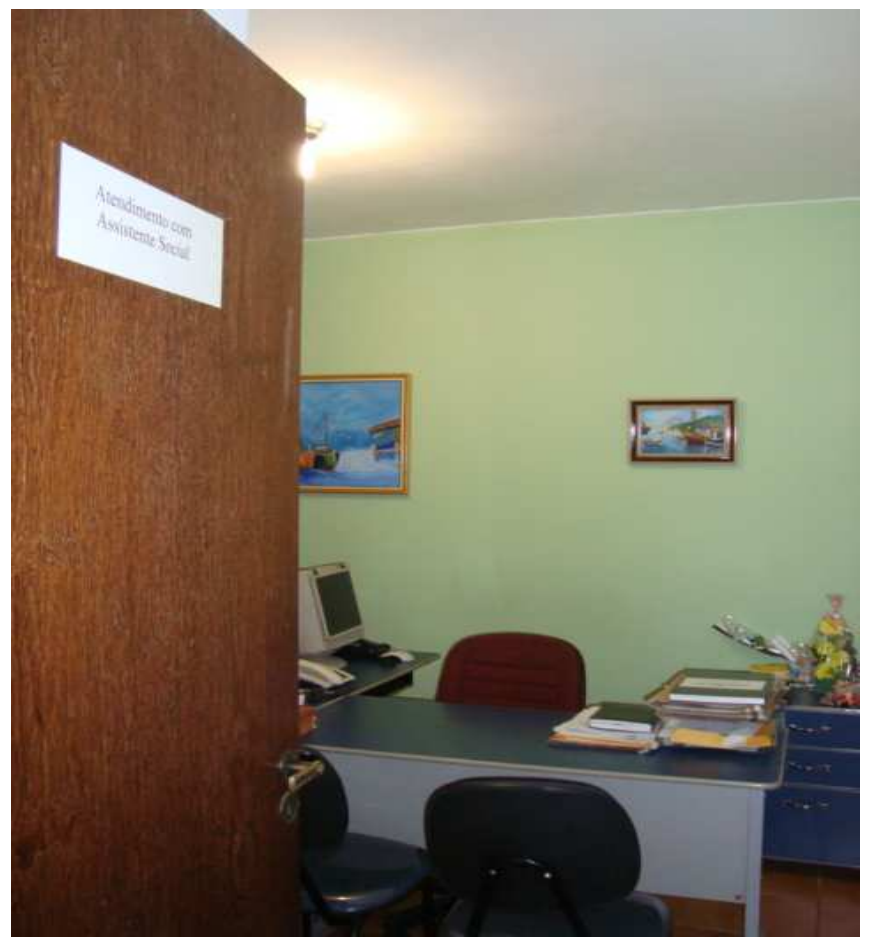

Foto 5 - Sala onde se realiza o atendimento com Assistente Social

\section{Psicologia}

A instituição conta com duas psicólogas que realizam duas vezes por semana, cada uma, atendimento individual aos pacientes e seus familiares, possibilitando um atendimento as segundas e sextas-feiras das 09:00 às 13:00, e as terças e quintas-feiras das 14:00 às 17:00.

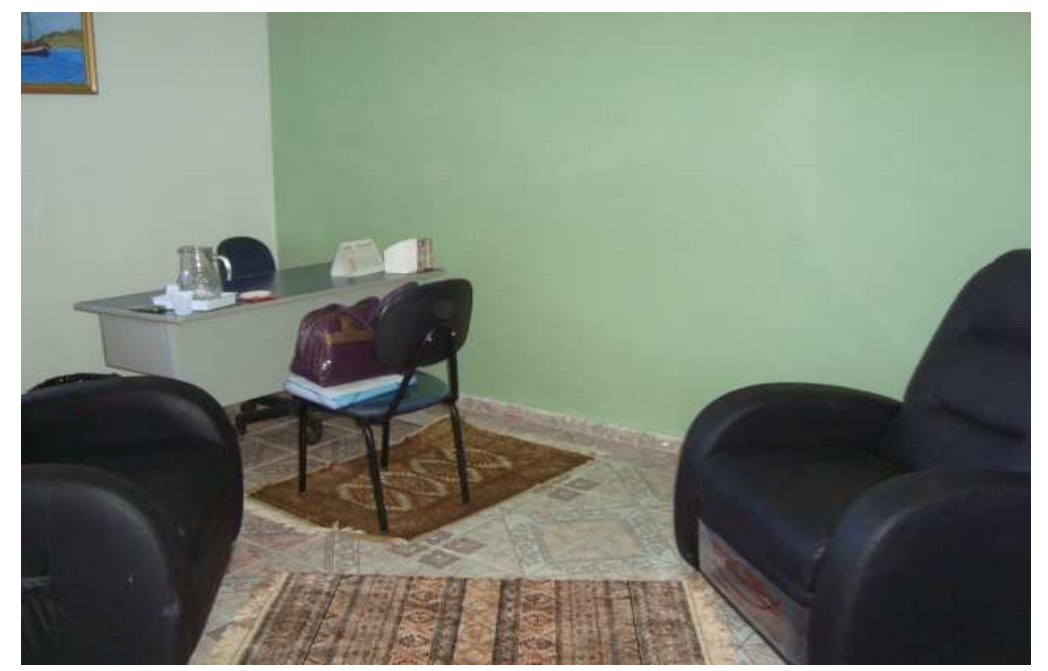

Foto 6 - Sala onde é realizado o atendimento psicológico 


\section{Nutrição}

Os pacientes recebem, constantemente, orientações sobre alimentação saudável que se dá tanto por meio de palestras, como individualmente. Quando o atendimento nutricional é personalizado, ou seja, realizado individualmente, é feito por uma nutricionista voluntária que atende uma vez por semana, geralmente quarta-feira, das 14:00 às 16:30. A nutricionista participa também na montagem da cesta básica da ABRAPEC, indicando os alimentos necessários para uma boa alimentação dos pacientes.

\section{Distribuição de cesta básica}

Todos os meses a maioria dos pacientes recebem uma cesta básica com os itens fundamentais a alimentação humana. Os mantimentos recebidos por meio de doação ficam armazenados em uma sala (Foto 7 ), para que posteriormente, de acordo com a necessidade observada, sejam incluídos em uma cesta básica. $A$ entrega dos mantimentos é feita todas as terças-feiras das 9:00 às 10:30 de acordo com uma escala previamente estabelecida.

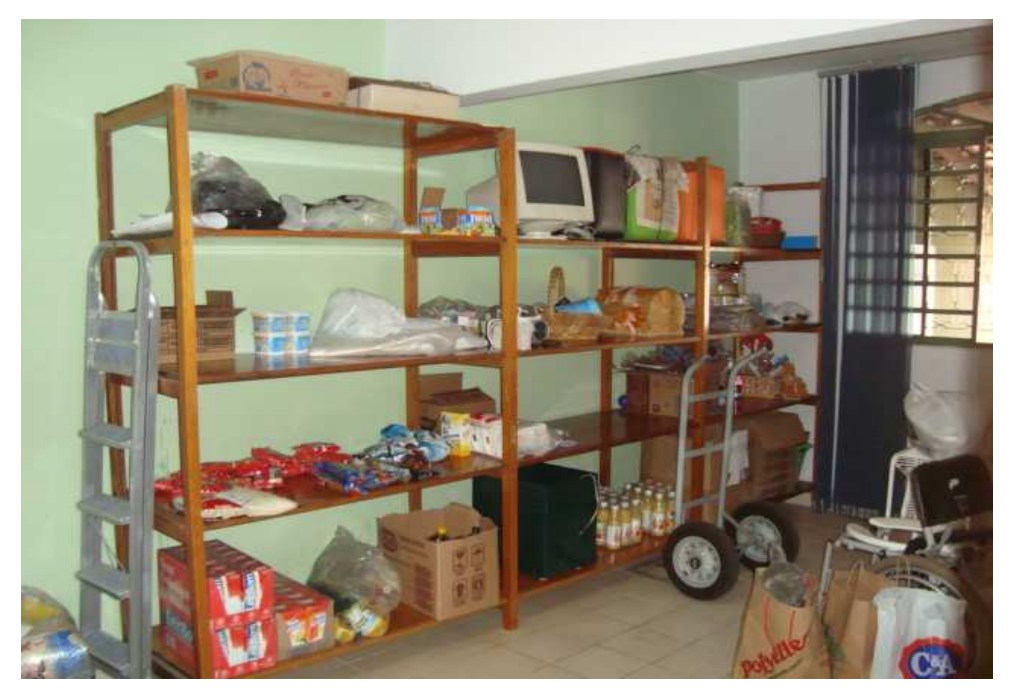

Foto 7 - Sala onde são armazenados os mantimentos recebidos pela instituição e outros objetos frutos de doação

\section{Palestras}

Sempre que há algum assunto de interesse e, voluntários dispostos a fazê-lo, palestras são oferecidas as terças-feiras das 9:00 às 10:30, com o objetivo de 
manter os pacientes informados sobre temas atuais de prevenção, orientação e educação. As mesmas ocorrem em um ambiente improvisado (Foto 8) mas que tem atendido eficientemente a demanda da instituição.

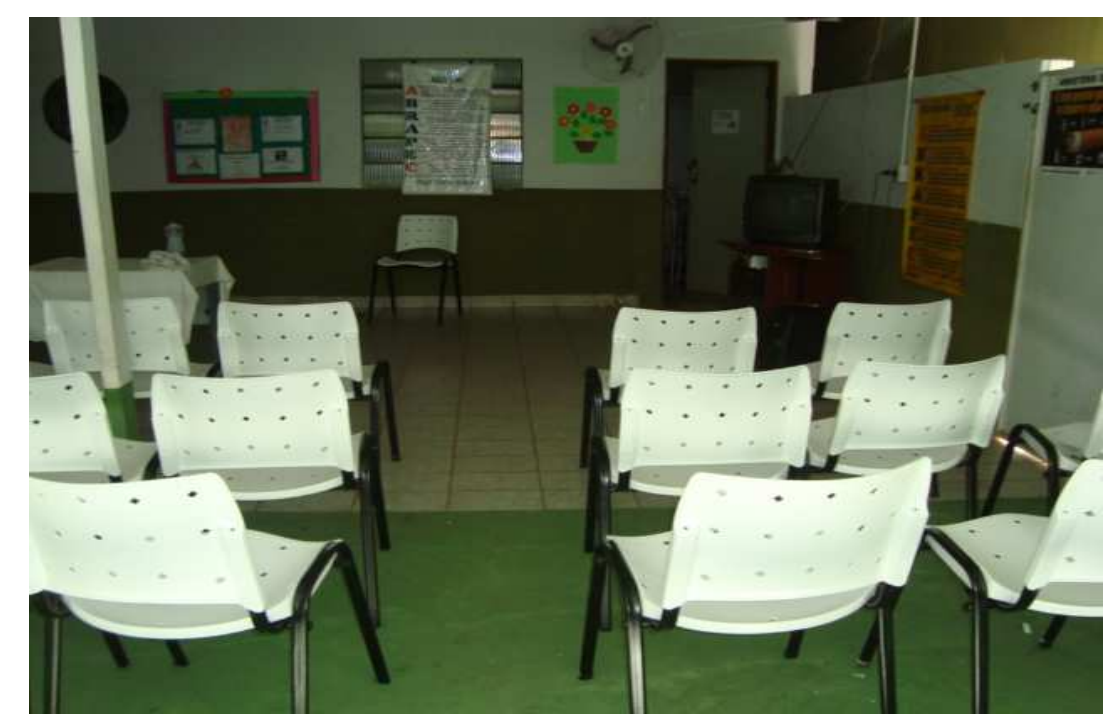

Foto 8 - "Sala" onde os pacientes são recebidos diariamente e onde ocorrem as palestras

A exemplo disto, no dia 22 de setembro de 2009 a unidade de Taguatinga ofereceu aos seus pacientes uma palestra sobre a Influenza H1N1 (Foto 9) com a finalidade de tranqüilizá-los, tendo em vista que os mesmos fazem parte do grupo de risco por apresentarem o sistema imunológico baixo.

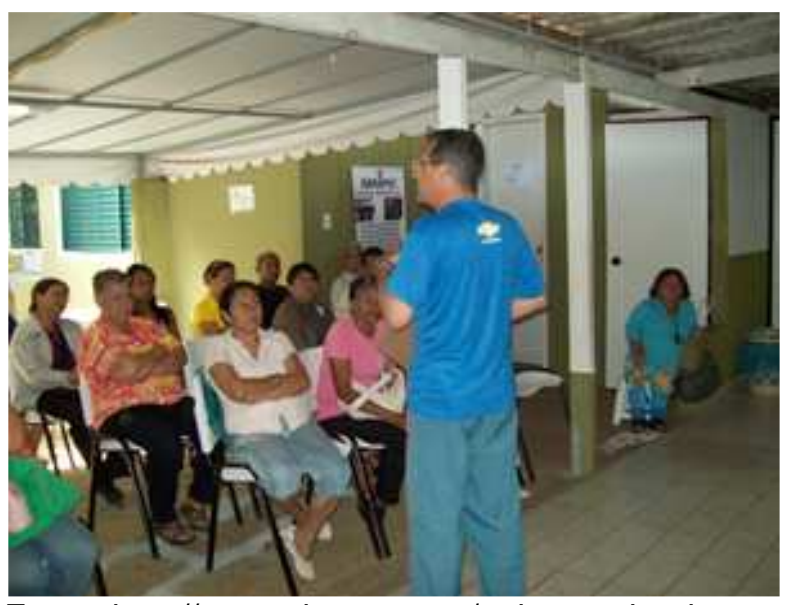

Fonte: http://www.abrapec.org/palestras.html

Foto 9 - Palestra sobre Prevenção Gripe Influenza H1N1 


\section{Jurídico}

Os pacientes contam também com assistência jurídica, por meio da qual um advogado, também voluntário, os auxiliam em casos relacionados aos direitos da pessoa portadora de câncer. Este serviço é oferecido uma vez por mês, no entanto não possui dia e hora definidos, tendo em vista depender da disponibilidade de horário do voluntário para realizá-lo.

\section{Auriculoterapia}

Tendo em vista as patologias (insônia, depressão, gastrite, etc.) que acometem os pacientes portadores de câncer a ABRAPEC oferece uma técnica de reflexoterapia que utiliza o pavimento auricular para estimulo do Sistema Nervoso Central e conseqüente tratamento das enfermidades desenvolvidas pelos pacientes devido ao tratamento a que são submetidos. Uma terapeuta voluntária realiza o atendimento, que inclui uma anaminese (entrevista), as quintas-feiras das 9:00 às 11:00.

\section{Capoterapia}

Terapia que utiliza os elementos da capoeira adaptados para pessoas da terceira idade, a capoterapia visa oferecer melhor qualidade de vida aos seus adeptos, criando hábitos saudáveis de realização de atividade física, alimentação, higiene e lazer; proporcionando também maior integração grupal e a ampliação do círculo de amizades. Na ABRAPEC As sessões ocorrem normalmente na ultima quinta-feira do mês, quando ocorre também, a comemoração dos aniversários do mês.

\section{Terapia comunitária}

Caracterizada por um espaço de convivência social onde o objetivo principal é reunir pessoas, trocar experiências e expandir conhecimentos e pontos de vista sobre emoções que todos nós sentimos, a terapia comunitária é uma atividade de grande relevância para os pacientes da ABRAPC, pois além de ajudá-los na superação de problemas acarretados pelo câncer, contribui para o desenvolvimento 
das relações interpessoais dos mesmos. Essa atividade é realizada a cada quinze dias, geralmente as quintas-feiras das 9:00 às 10:30.

\section{Terapia corporal (Psicoterapia de grupo)}

Por tratar as questões humanas considerando o corpo e a mente, a terapia corporal permite aos pacientes um processo de intensa mudança e limpeza emocional, proporcionando relaxamento das estruturas físicas contraídas, trazendo novamente a capacidade de sentir, aumentando o fluxo de energia e ampliando a percepção. Ela atua principalmente procurando encontrar caminhos que resgatem a pulsação paralisada por traumas, faltas, excessos e tudo o que o indivíduo não conseguiu digerir ou integrar no seu psiquismo Por meio desta atividade, os pacientes da ABRAPEC desenvolvem e fazem uso de expressões corporais que ajudam principalmente na diminuição do estresse e de problemas de circulação sanguínea. Atualmente a terapia corporal é trabalhada a cada quinze dias, mais precisamente as quintas-feiras das 09:00 às 10:30.

\section{Terapia de relaxamento}

O relaxamento corporal é uma das diversas técnicas utilizadas para promover o conhecimento e o controlo do nosso corpo. Nessa terapia a utilização de técnicas de respiração é comum, pois contribui para melhoria do sono daqueles que sofrem de insônia e permite que os pacientes aprendam, também, técnicas de automassagem que auxiliam na redução do estresse e de problemas de circulação sanguínea.

\section{Massagem terapêutica}

A instituição conta com uma sala especialmente equipada para a realização da massagem terapêutica (Foto 10). Todas as quintas-feiras das 9:00 às 11:00, uma terapeuta voluntária realiza a massagem nos pacientes que demonstram interesse. Quando praticada regulamente, a massagem auxilia no tratamento, pois além de ajudar na diminuição de dores musculares, beneficia os pacientes na medida em que alivia a ansiedade e o estresse presentes, principalmente, no período em que se realiza a radioterapia e a quimioterapia. 


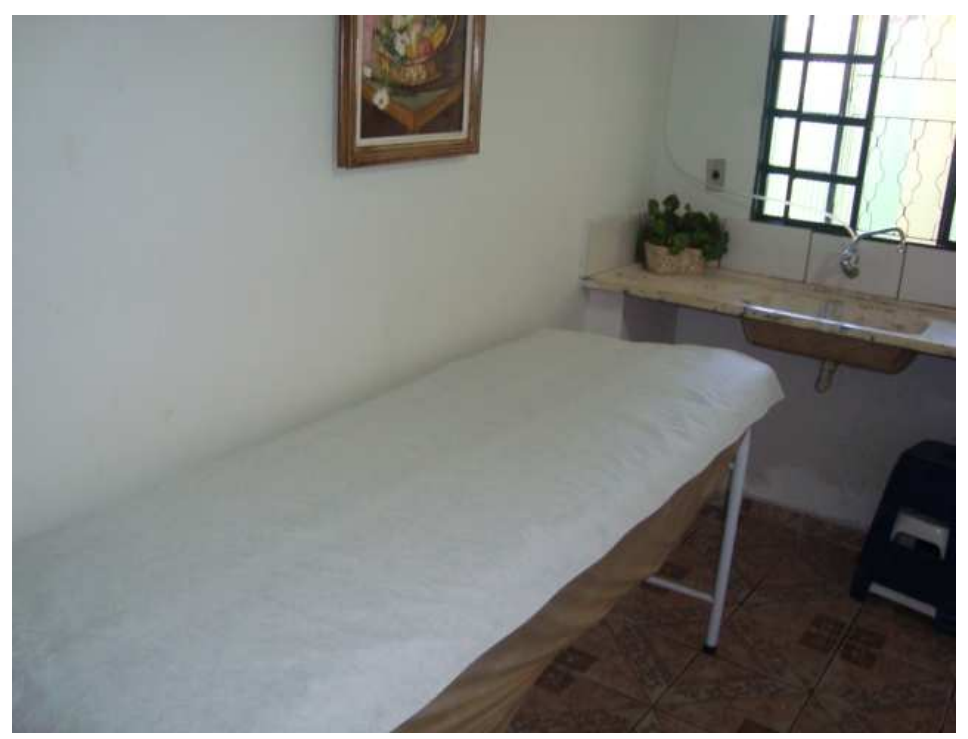

Foto 10 - Sala onde é realizada a Massagem terapêutica

\section{Projeto Educação de Jovens e Adultos}

Por meio deste projeto os pacientes não-alfabetizados têm a oportunidade de estudar. As aulas acontecem todas as segundas e quartas-feiras de 8:30 às 11:00 na ABRAPEC (Foto 11) e sextas-feiras das 14:00 às 15:30 na Faculdade de Ciências Sociais e Tecnologia - FACITEC, sendo essas destinadas ao ensino de noções de informática. Ao concluírem o curso, os alunos recebem certificado de conclusão e se passarem no vestibular da FACITEC, recebem bolsa integral para fazer um curso superior naquela instituição.

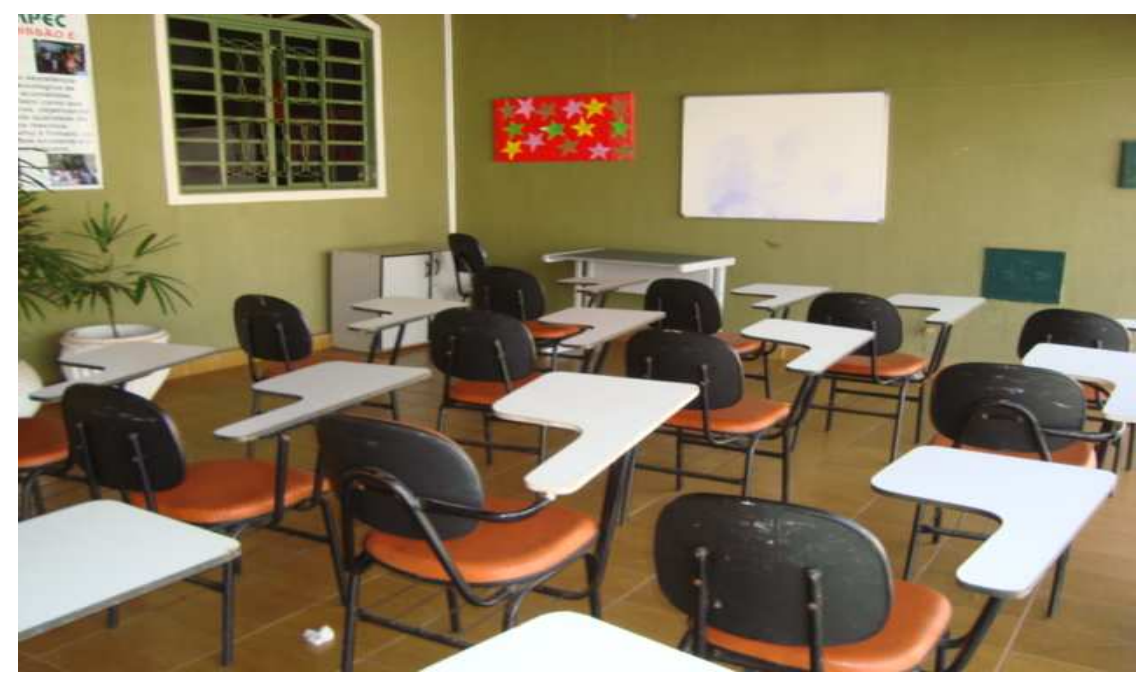

Foto 11 - "Sala" onde os alunos do EJA tem as aulas 


\section{Oficinas}

Diversas oficinas são oferecidas aos pacientes, dentre as quais oficinas de arte, costura, culinária, artesanato e teatro. Além de ajudarem na melhoria do bem estar dos pacientes, elas proporcionam um meio de sustento, já que muitos deles não possuem emprego no mercado formal de trabalho. Atualmente as oficinas que estão sendo realizadas são a de artesanato e de costura. Ambas são realizadas semanalmente sendo a primeira as segundas-feiras das 14:00 às 16:00 e a ultima as sextas-feiras também das 14:00 às 16:00. A ABRAPEC conta com um espaço reservado para a realização da oficina de costura e também com as máquinas de costura (Foto 12) para que as alunas coloquem em prática o que foi aprendido.

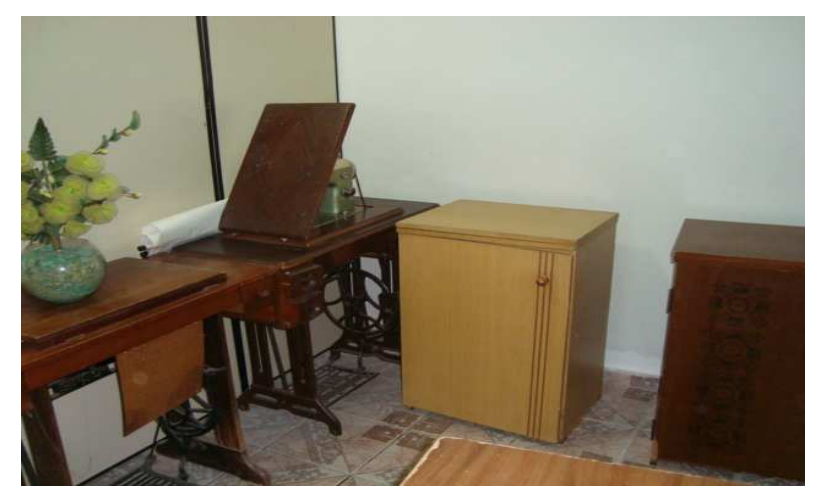

Foto 12 - Maquinas de costura utilizadas na oficina de costura

A ABRAPEC realiza também diversos eventos em datas comemorativas (Fotos 13 e 14) - dia das mães, dia dos pais, páscoa, festas juninas e natalinas - e passeios a diferentes destinos. Uma vez por mês promove o Dia da Beleza por meio do qual os pacientes têm direito a corte de cabelo, escova, maquiagem e manicure.

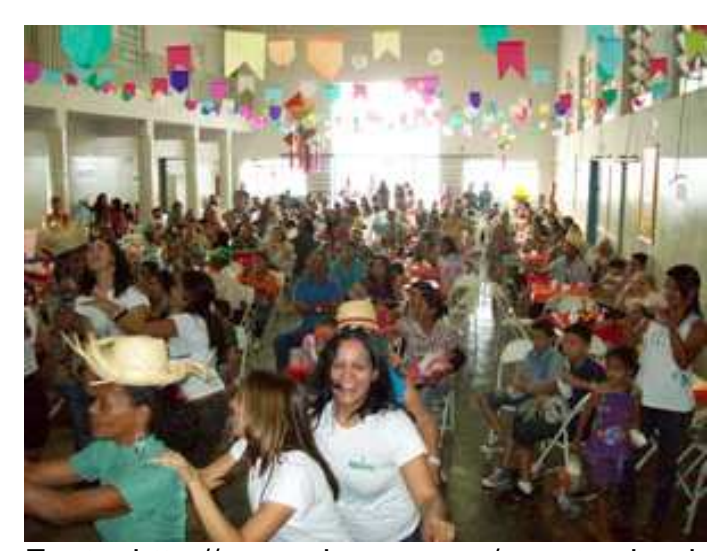

Fonte: http://www.abrapec.org/eventos.html

Foto 13 - Festa junina

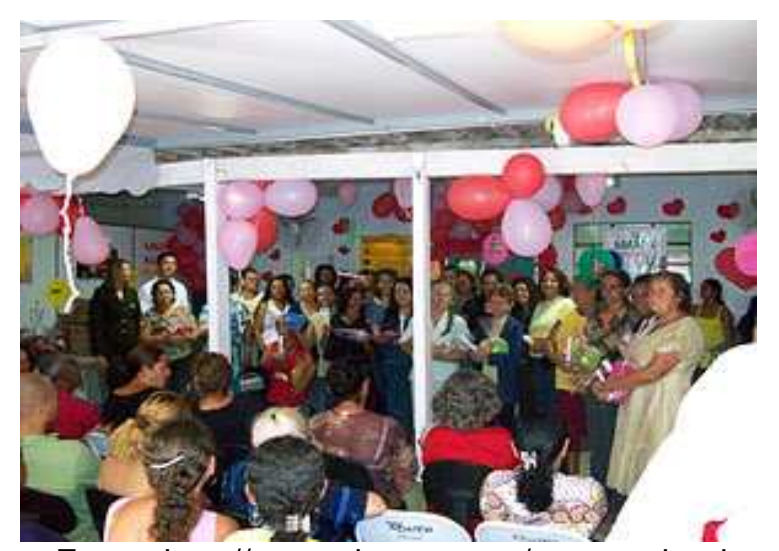

Fonte: http://www.abrapec.org/eventos.html

Foto 14 - Comemoração dia das mães 
Todas as atividades oferecidas pela Instituição são realizadas com o objetivo principal de ajudar a elevar a auto-estima dos pacientes. Além disso, nem sempre são realizadas e oferecidas com a mesma freqüência apresentada, tendo em vista que a realização das mesmas depende da disponibilidade de voluntários, espaço físico e o mais importante, do interesse apresentado pelos pacientes participar das atividades.

\subsubsection{Biblioteca da ABRAPEC-DF}

Atualmente a biblioteca da ABRAPEC-DF é constituída por uma prateleira com livros (Foto 15) que foram adquiridos por meio de doações. Além de possuir um acervo pequeno e com assuntos pouco atrativos, está desatualizado e a algum tempo não recebe novos livros. Os livros estão organizados por assunto, identificados na estante por meio de etiquetas, no entanto, não passam por nenhum tipo de processamento técnico antes de irem para esta pequena estante que os comporta.

Quanto às instalações físicas, existe a falta de espaço para a implantação de uma biblioteca que possa oferecer um acervo maior, bem como outros serviços aos pacientes.

Os pacientes mais interessados na utilização desse acervo são os que participam do Projeto Educação de Jovens e Adultos, que quando demonstram interesse na utilização dos livros o fazem, porém sem nenhum tipo de ajuda ou controle do empréstimo, pois ainda não foi implantado um software nem outro meio manual para efetuá-los. 


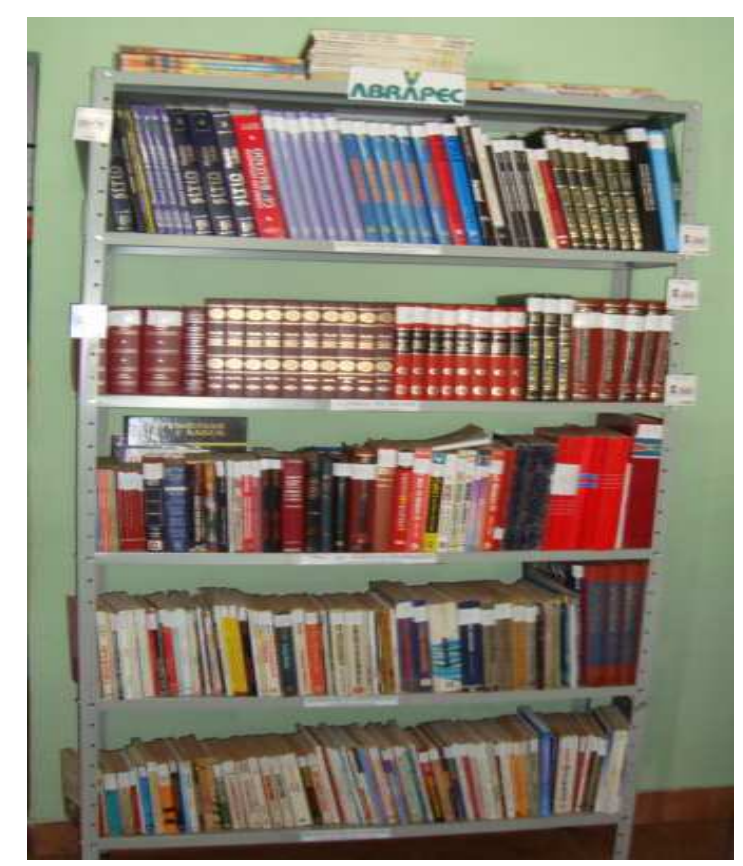

Foto 15 - Estante de livros da ABRAPEC-DF

\subsection{Perfil dos usuários da biblioteca}

Para elaboração do perfil dos pacientes foram realizadas duas pesquisas descritivas: uma com os pacientes, e outra com os funcionários e voluntários da ABRAPEC/DF.

\subsubsection{Perfil dos pacientes}

Para o estabelecimento do perfil dos pacientes foi elaborado um roteiro de uma entrevista (Anexo A) com os seguintes objetivos:

- Verificar se os pacientes da ABRAPEC possuem o hábito de ler.

- Identificar os assuntos que os pacientes da ABRAPEC costumam ler e aqueles que eles possuem interesse.

- Verificar se os pacientes consideram importante a criação de uma biblioteca na ABRAPEC. 


\section{Coleta e processamento dos dados}

Para a coleta de dados dos pacientes foram feitas entrevistas estruturadas, em formato de questionário, conforme Anexo B, com 17 questões, sendo uma em aberto para sugestões.

Dos 120 pacientes atuais da Instituição, foram entrevistados 40, que correspondem a $33,33 \%$ do total de pacientes.

Esta pesquisa foi realizada nos meses de setembro e outubro de 2009. A maioria dos respondentes foi abordada no dia da entrega de cestas básicas.

A partir dos dados coletados foram elaboradas tabelas no Excel, que se constituíram nos elementos da análise dos dados.

\section{Análise dos dados}

Os dados obtidos revelaram que dos 40 respondentes, 32 (80\%) são mulheres e 8 (20\%) são homens, conforme Figura 8:

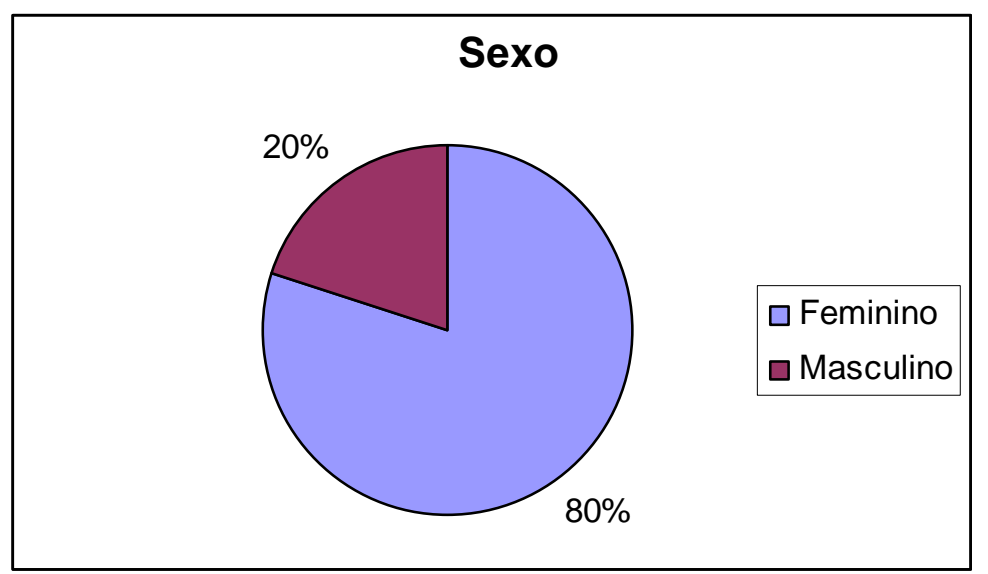

Figura 8 - Sexo dos pacientes

Quanto à faixa etária, a maioria dos pacientes (52\%) possui mais de 50 anos, porém verifica-se que existem pacientes a partir de 11 anos, de acordo com a Figura 9: 


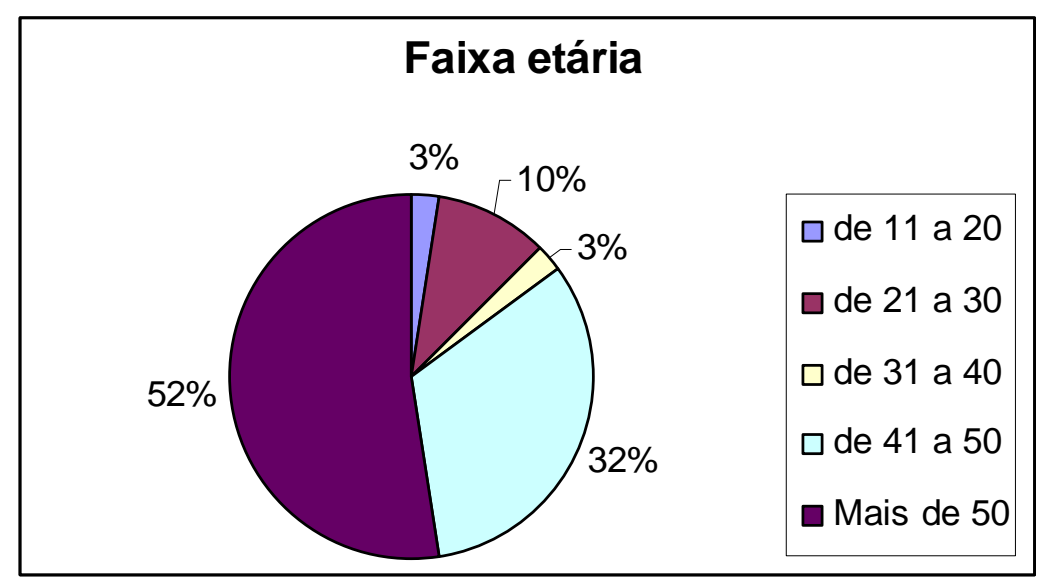

Figura 9 - Faixa etária dos pacientes

Constata-se que a maioria dos usuários freqüenta a ABRAPEC a mais de um ano. Dos 40 pacientes entrevistados, apenas $3(8 \%)$ estão a menos de um ano na instituição, o que pode ser observado na Figura 10:

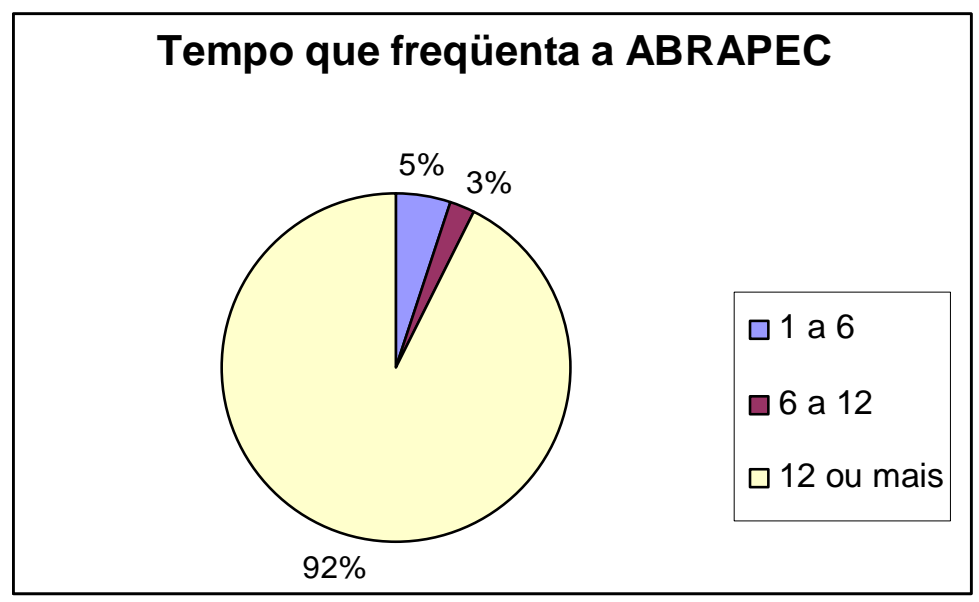

Figura 10 - Tempo que os pacientes freqüentam a ABRAPEC

Quanto à freqüência desses pacientes na ABRAPEC, observa-se que 34\% da amostra analisada vão a ABRAPEC uma por semana. E que $20 \%$ vão pelo menos 2 vezes por semana. Isso mostra o interesse dos usuários de participarem das atividades que são desenvolvidas ao longo da semana. Os pacientes que vão apenas uma vez por mês (18\%) a Instituição, em geral, comparecem no dia que ocorre a entrega de cesta básica, e afirmam que isso ocorre devido morarem longe da ABRAPEC, como pode se observar na Figura 11: 


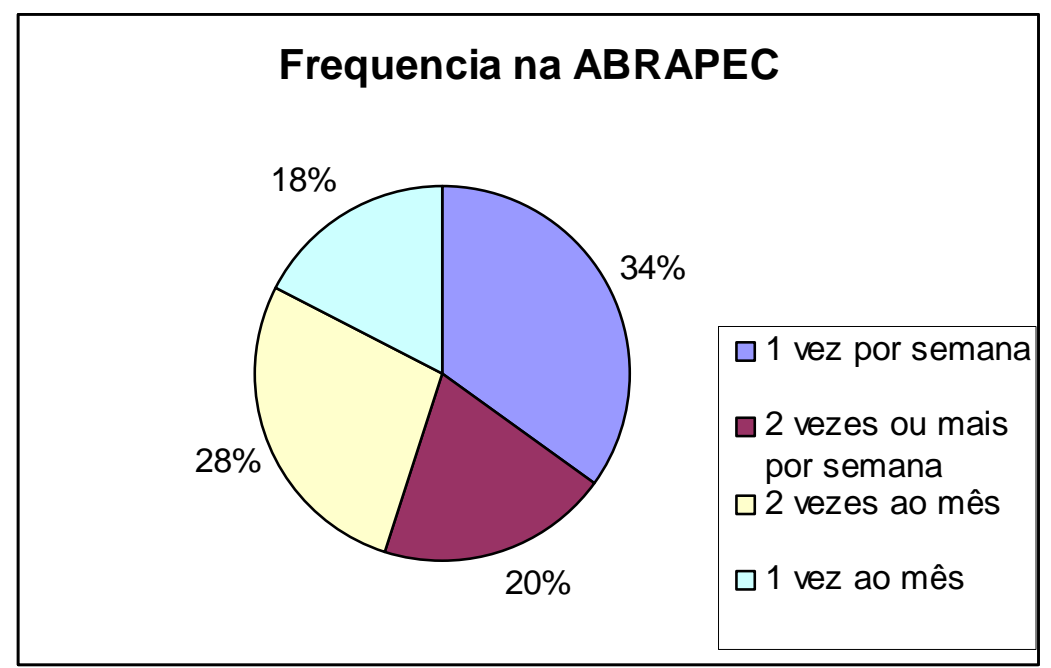

Figura 11 - Freqüência com que os usuários vão a ABRAPEC

O nível de instrução dos pacientes é baixo: 4 (10\%) dos entrevistados não sabem ler; 2 (5\%) estão aprendendo no EJA e a maioria (49\%) possui apenas o ensino fundamental incompleto. Constata-se também que só $10 \%$ dos entrevistados concluíram o ensino médio e que nenhum possui nível superior completo. Apenas 1 (3\%) possui nível superior incompleto. Esse paciente começou este ano o curso de teologia, após ter freqüentado o projeto EJA, o que mostra a importância dessa atividade desenvolvida na ABRAPEC. Esses e outros dados a respeito do nível de instrução dos pacientes dessa instituição podem ser verificados na Figura 12:

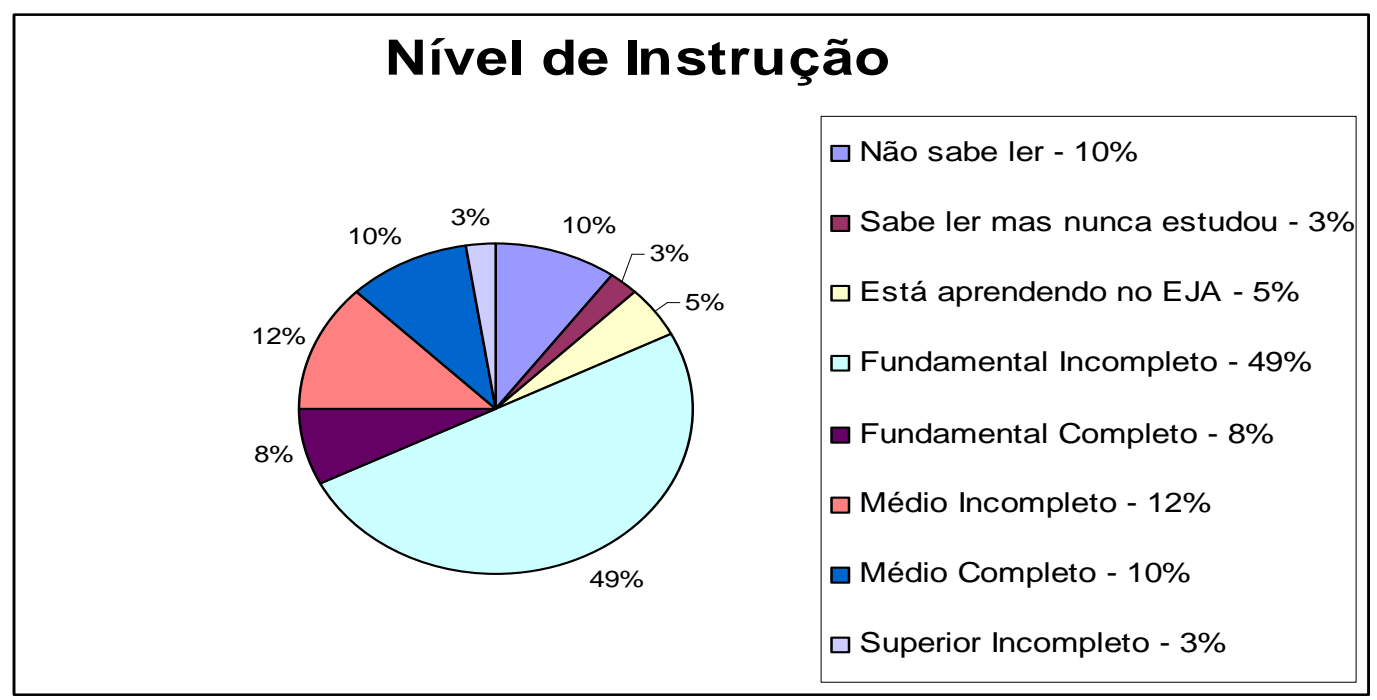

Figura 12 - Nível de Instrução dos Pacientes da ABRAPEC 
Embora a maioria (77\%) afirme gostar de ler, de acordo com a Figura 13, é possível notar que grande parte dos pacientes não possui o hábito da leitura:

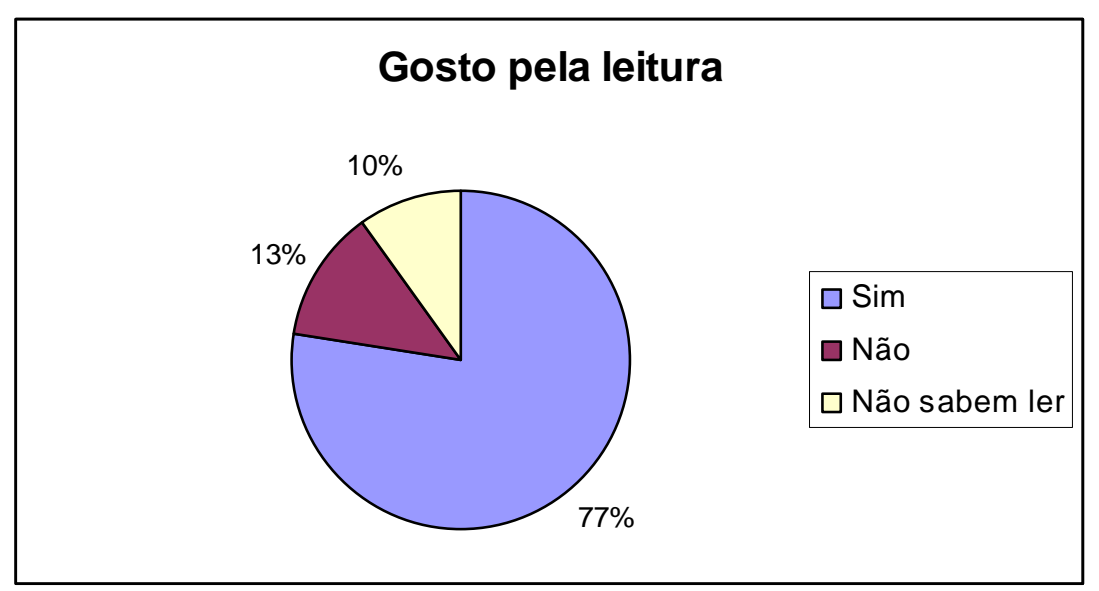

Figura 13 - Gosto pela leitura dos pacientes da ABRAPEC

Dos 40 respondentes 18 (44\%) declaram que lêem esporadicamente, somente quando aparece algo que seja do seu interesse, conforme a Figura 14. Os pacientes que lêem diariamente, em sua maioria, lêem a Bíblia:

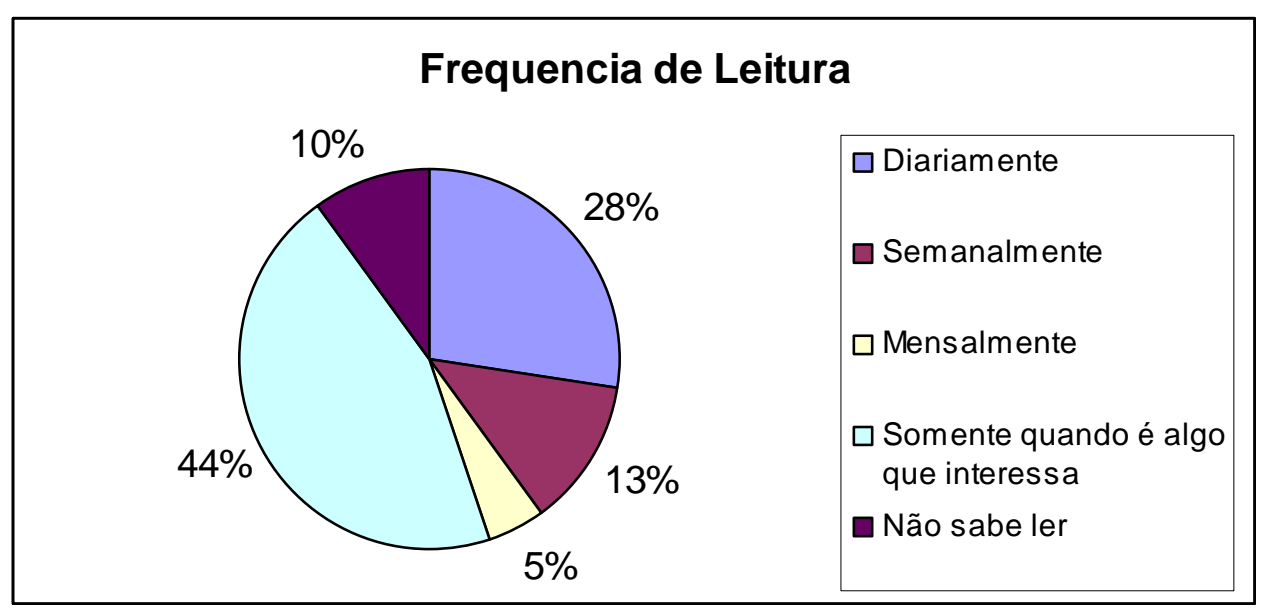

Figura 14 - Freqüência de Leitura dos pacientes da ABRAPEC

Quando os pacientes lêem, a maioria prefere ler sobre: atualidade, câncer, corte e costura, plantas, literatura, novelas, bordado, saúde, jardins, conforme demonstra a Figura 15. Além desses assuntos lêem também sobre: culinária, autoajuda, arte, saúde, esporte, decoração, sobre artistas, carro, música, direcionados 
para concursos e vestibular, animais, ciencias, história, santos, artesanato, religião, historias em quadrinho, enfim, um pouco de tudo.

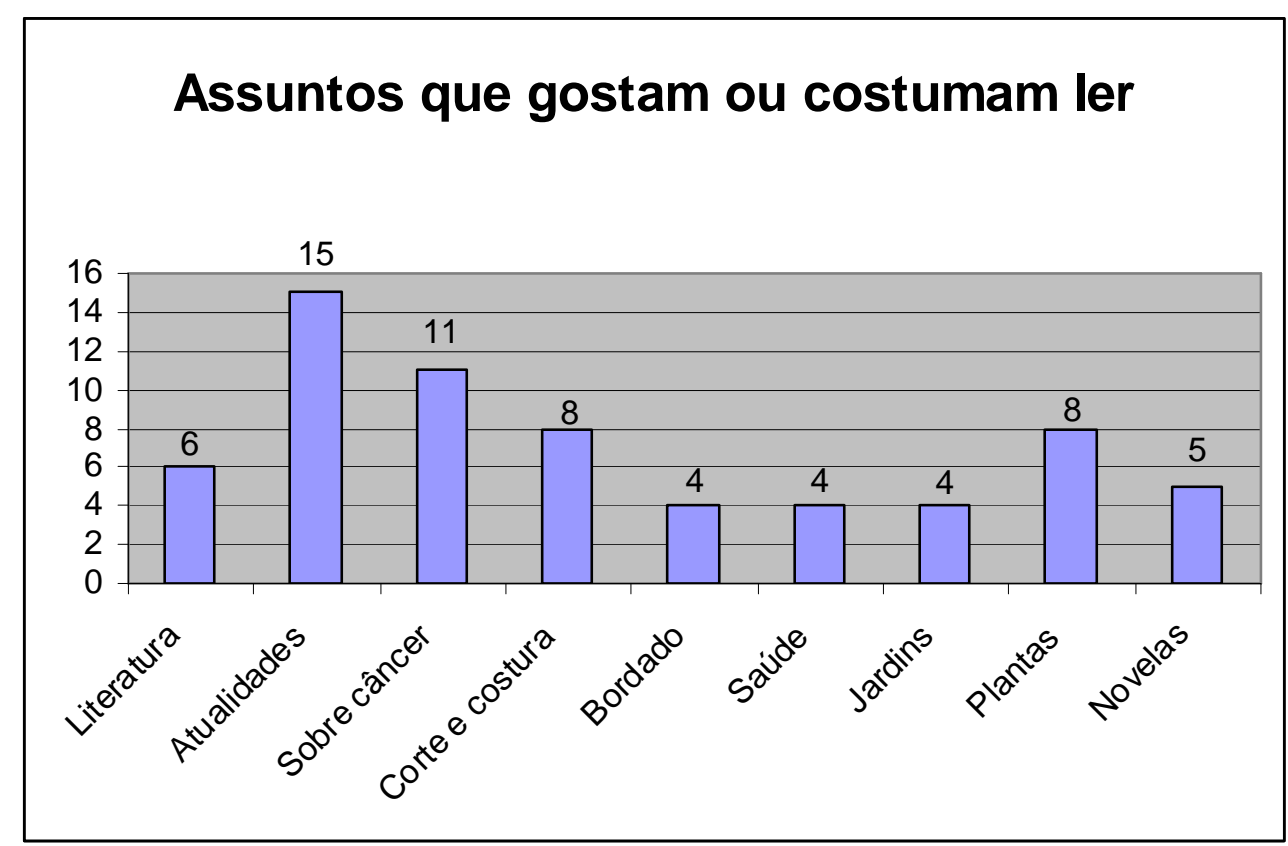

Figura 15 - Assuntos que os pacientes da ABRAPEC gostam ou costumam Ler

A idéia de se criar uma biblioteca na ABRAPEC foi aceita pelos pacientes da Instituição, pois 23 (57\%) deles consideram ótima a idéia e afirmam que freqüentariam a biblioteca. Apenas 5 (13\%) pacientes falaram que não frequentariam, 4 (10\%) deles por não saberem ler e 1 (3\%) por não gostar de ler.

\section{Opinião sobre se ter uma Biblioteca na ABRAPEC}

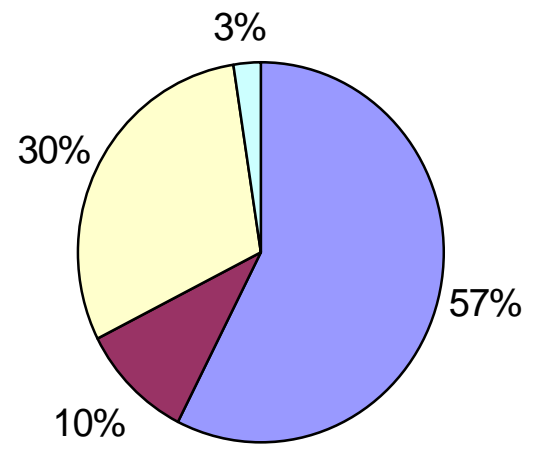

๑ Ótimo - Frequentária

Ótimo - Mas não frequentária

$\square$ Bom - Frequentária

$\square$ Bom - Mas não frequentária

Figura 16 - Opinião sobre a criação de uma Biblioteca na ABRAPEC 
Mais da metade dos pacientes da ABRAPEC (57\%) utiliza os livros que a ABRAPEC possui, os que não utilizam (43\%) justificam o não uso por: não saberem ler, falta de oportunidade, falta de interesse, falta de tempo, possuir livros em casa ou não ter o hábito de ler, como demonstra a Figura 17:

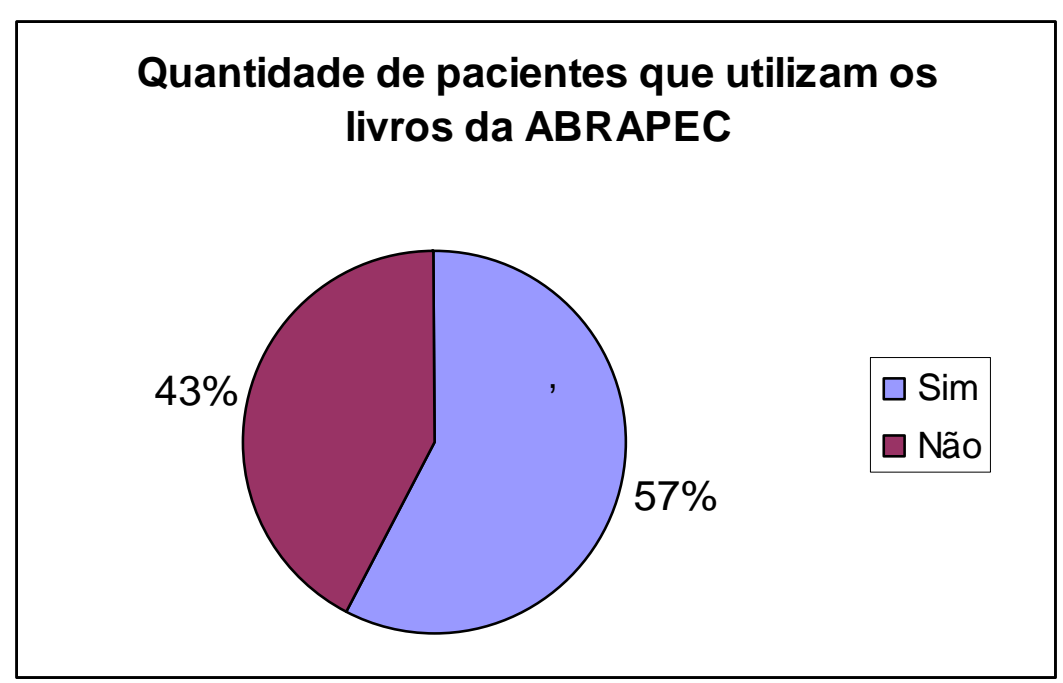

Figura 17 - Quantidade de pacientes que utilizam os livros da ABRAPEC

De acordo com a Figura 18, quase todos os entrevistados (92\%) consideram importante a Biblioteca da ABRAPEC possuir revistas e livros para que eles possam manter-se atualizados.

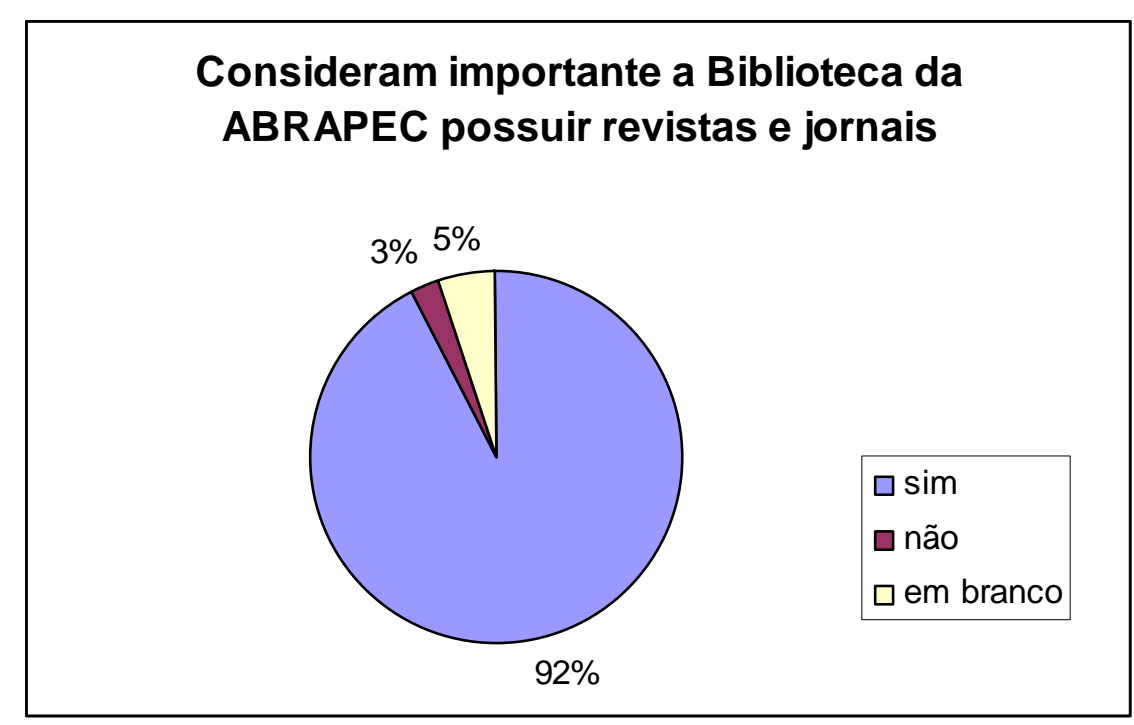

Figura 18 - Quantidade de pacientes que consideram importante a Biblioteca da ABRAPEC possuir revistas e jornais 
$\mathrm{Na}$ Figura 19, são apresentados os assuntos julgados como os mais importantes para se ter na Biblioteca da ABRAPEC. Foram citados os seguintes assuntos na ordem de preferência: câncer, atualidades, saúde, culinária, plantas, corte e costura, e literatura. Além desses foram citados, com menor freqüência, os assuntos: bordado, auto-ajuda, arte, esporte, jardins, decoração, novelas, artistas, carro, música, livros didáticos e livros direcionados para concursos e vestibular.

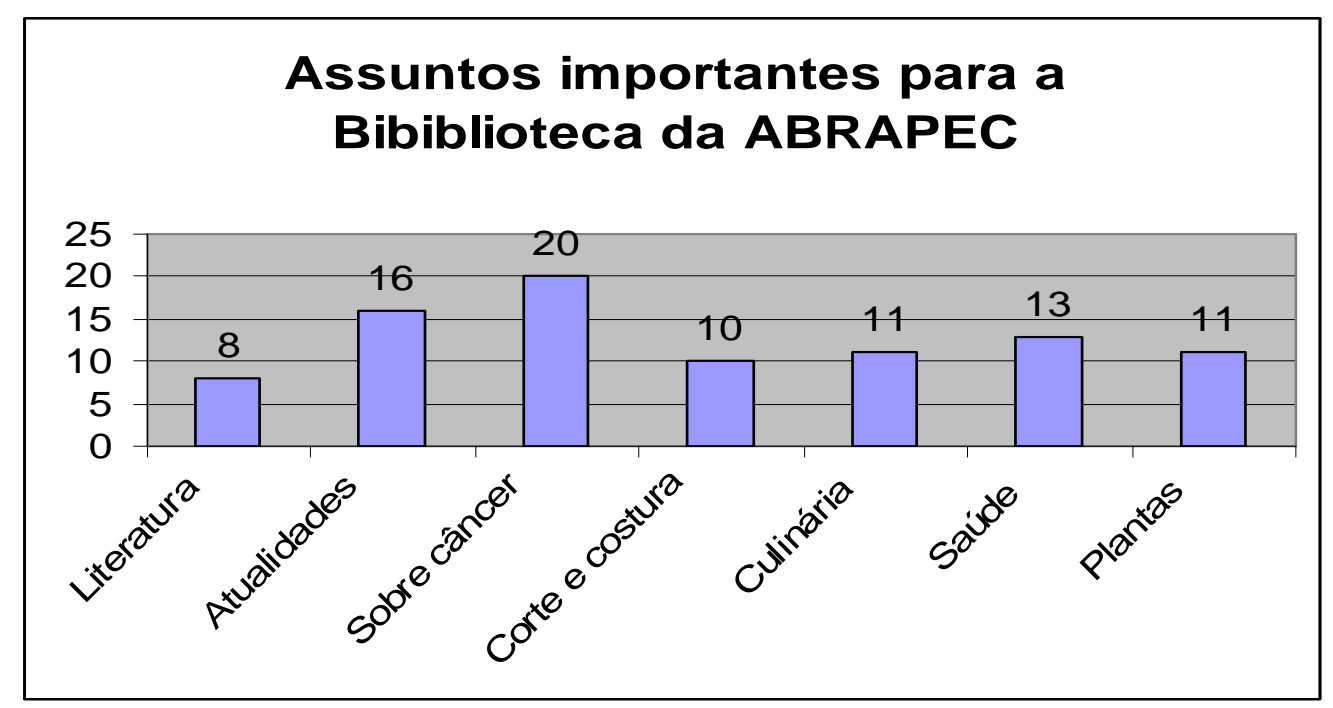

Figura 19 - Assuntos que os pacientes consideram importante ter na Biblioteca da ABRAPEC

Todos os entrevistados acreditam que a leitura traz benefícios, mesmo os que não sabem ler e os que não gostam. Muitos deles (47\%) afirmam que o beneficio que a leitura traz é o enriquecimento intelectual, eles associam a leitura praticamente só a questão de estudos. Outros pacientes, entretanto relaciona a leitura também ao relaxamento (26\%), a motivação para o trabalho (16\%) e ao lazer (11\%). Isso pode ser observado na Figura 20 : 


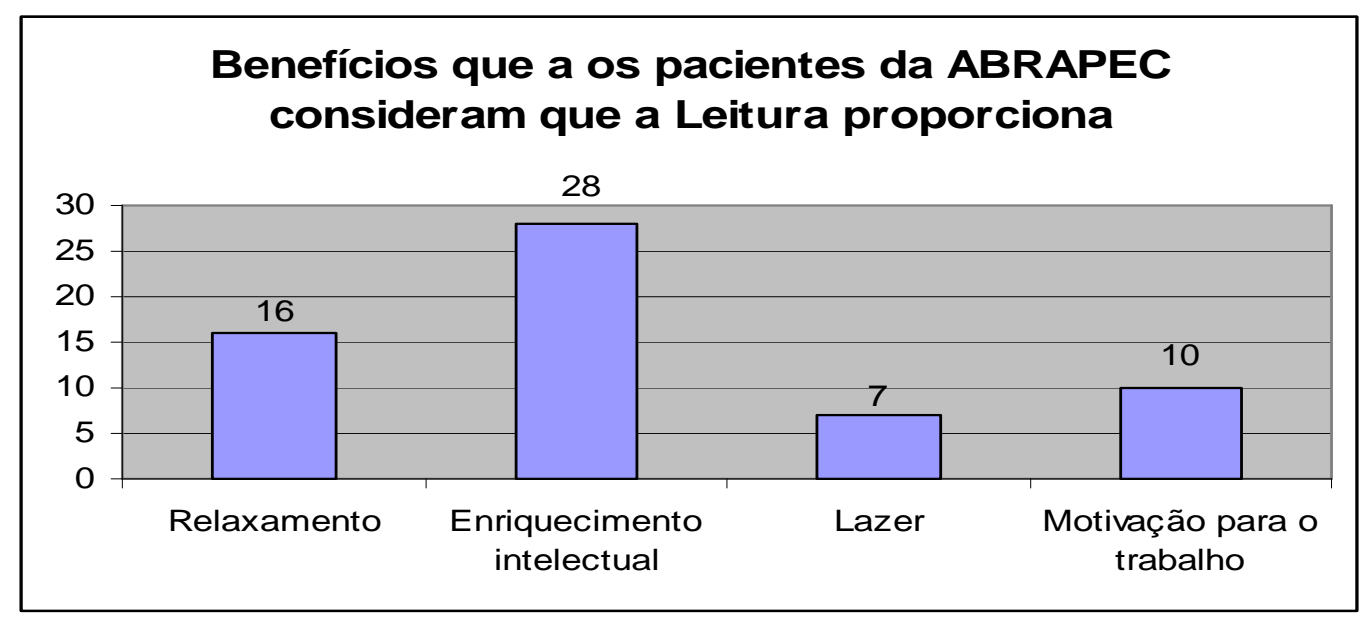

Figura 20 - Benefícios que os pacientes consideram que a leitura proporciona

Foram citados outros benefícios, como a distração, o autoconhecimento, o desenvolvimento pessoal, a memória, o desenvolvimento da mente e alguns associaram a leitura como forma de terapia. Comentaram a importância de saber ler para a realização de atividades básicas como assinar documentos, pegar ônibus e se localizar.

Dos 40 entrevistados, 23 (52\%) relataram que não freqüentam bibliotecas. Os demais responderam que quando vão a biblioteca tem como objetivo: fazer pesquisa (13\%), ler livros (9\%), fazer empréstimos de livros (9\%), ler revistas e jornais (7\%), consultar dicionários e enciclopédias (4\%), ocupar o tempo livro (4\%) e acessar a Internet (2\%). A Figura 21 ilustra esses dados:

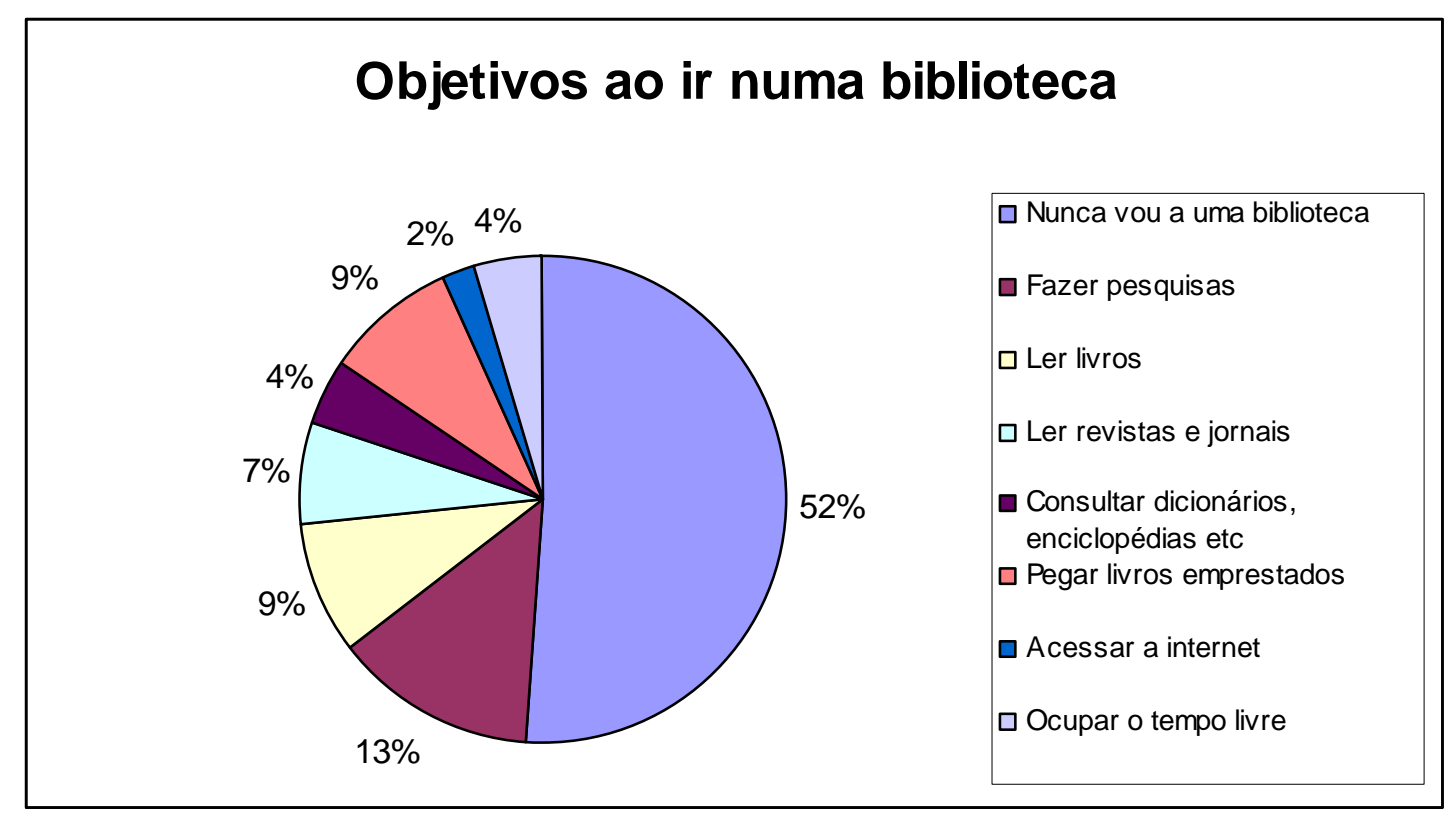

Figura 21 - Serviços que os pacientes da ABRAPEC buscam numa biblioteca 
Apenas $8(20 \%)$ pacientes deram sugestões para a criação da biblioteca da ABRAPEC/DF. As principais sugestões foram:

- Incentivar a leitura;

- Estimular a aprendizagem;

- Organizar um espaço maior e mais confortável para leitura;

- Oferecer variedades de livros;

- Possibilitar o acesso a Internet;

- Disponibilizar livros com assuntos atuais e interessantes, que façam com que os pacientes queiram freqüentar a biblioteca assiduamente.

\subsubsection{Perfil dos Funcionários e voluntários}

Com os funcionários e voluntários da ABRAPEC os questionários aplicados tiveram os seguintes objetivos:

- Verificar se consideram importante a criação de uma biblioteca na ABRAPEC.

- Identificar os assuntos bibliográficos que esses profissionais consideram importantes para o tratamento dos pacientes da Instituição.

- Identificar quais serviços eles consideram importantes que a biblioteca ofereça.

- Obter sugestões para a reestruturação da Biblioteca.

\section{Coleta e processamento de dados}

A coleta de dados dos funcionários foi feita por meio da aplicação de um questionário, com 12 questões, sendo uma em aberto para sugestões, conforme Anexo B.

Dos 8 funcionários da ABRAPEC, 4 responderam ao questionário: 2 são psicólogas, 1 recepcionista e 1 assistente social. Além dos 4 funcionários, 2 voluntários e 1 estagiária de serviço social participaram da pesquisa.

A pesquisa feita com os funcionários e voluntários da ABRAPEC foi respondida apenas por mulheres. Com relação à faixa etária delas é bem diversa, sendo que três (43\%) delas têm mais de 50 anos, 1 (14\%) tem entre 41 e 50 anos, 2 
(29\%) de 31 a 40, e 1 (14\%) possui entre 20 e 30 anos, o que pode ser observado na Figura 22:

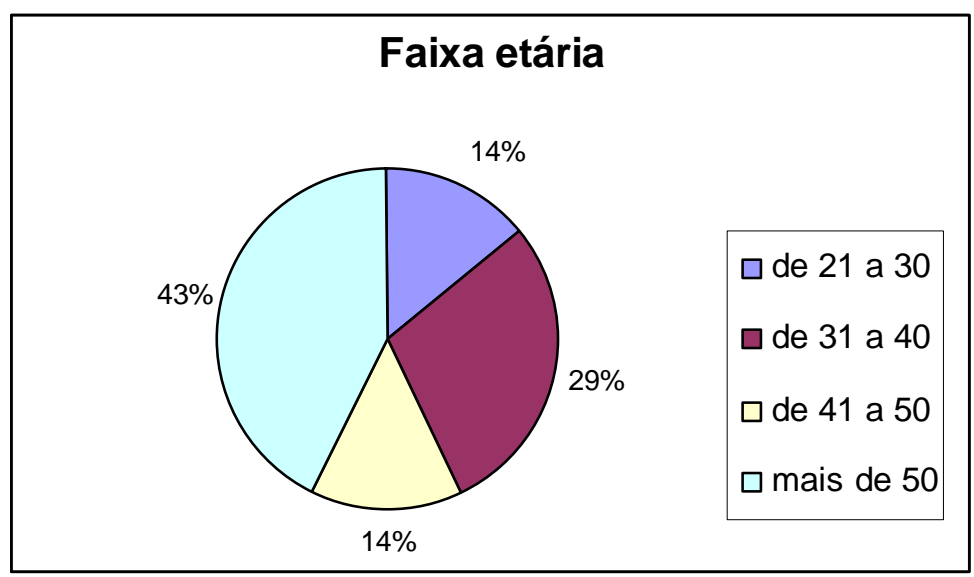

Figura 22 - Faixa etária das funcionárias e voluntárias da ABRAPEC

Quanto ao nível de instrução, como pode ser observado na Figura 23, a maioria das funcionárias e voluntárias respondentes possui alta escolaridade, sendo que $5(72 \%)$ delas possuem nível superior completo, 1 (14\%) possui nível superior incompleto e apenas 1 (14\%) nível fundamental incompleto.

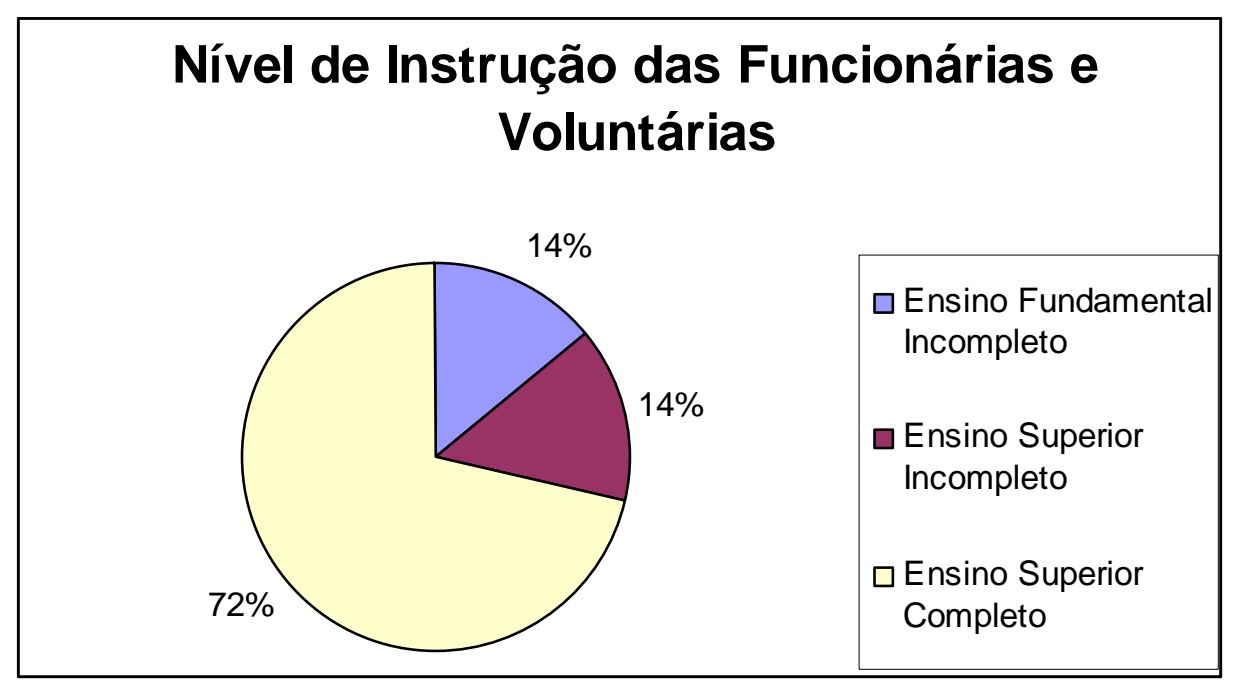

Figura 23 - Nível de Instrução das Funcionárias e Voluntárias da ABRAPEC

Com relação à utilização dos livros que a ABRAPEC possui, a pesquisa mostrou que das 7 respondentes, apenas 2 (29\%) não utilizam esses livros, devido falta de tempo. O que é demonstrado pela Figura 24: 


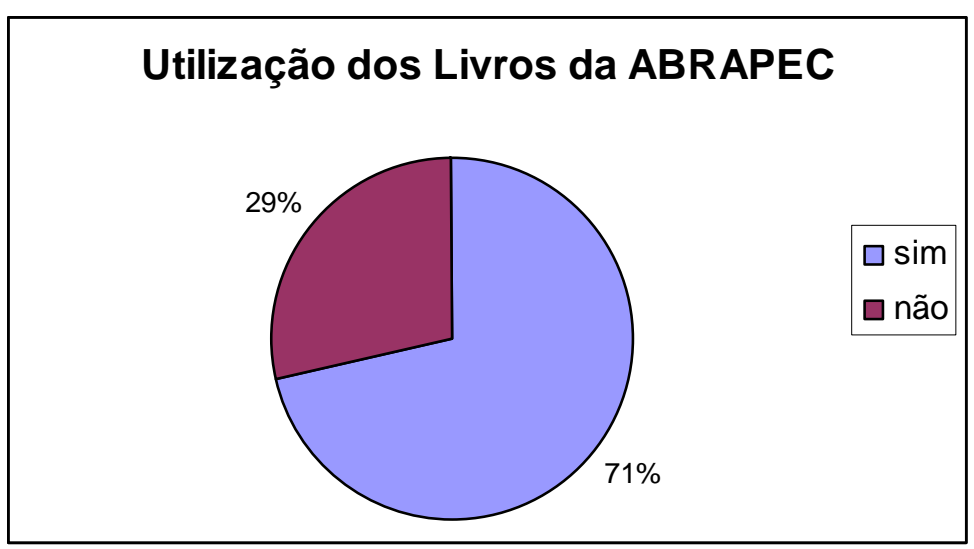

Figura 24 - Utilização dos livros da ABRAPEC pelos funcionários e voluntários

Quanto à existência de uma biblioteca na ABRAPEC, todas as respondentes consideram importante, para que os usuários tenham acesso à informação e para que a leitura seja incentivada.

Elas consideram como assuntos relevantes para se ter na biblioteca da ABRAPEC: atualidades (6), Literatura (5), Auto-ajuda (5), câncer (5), Arte (3), jardins (3) e plantas (3). Isso pode ser visualizado na Figura 25:

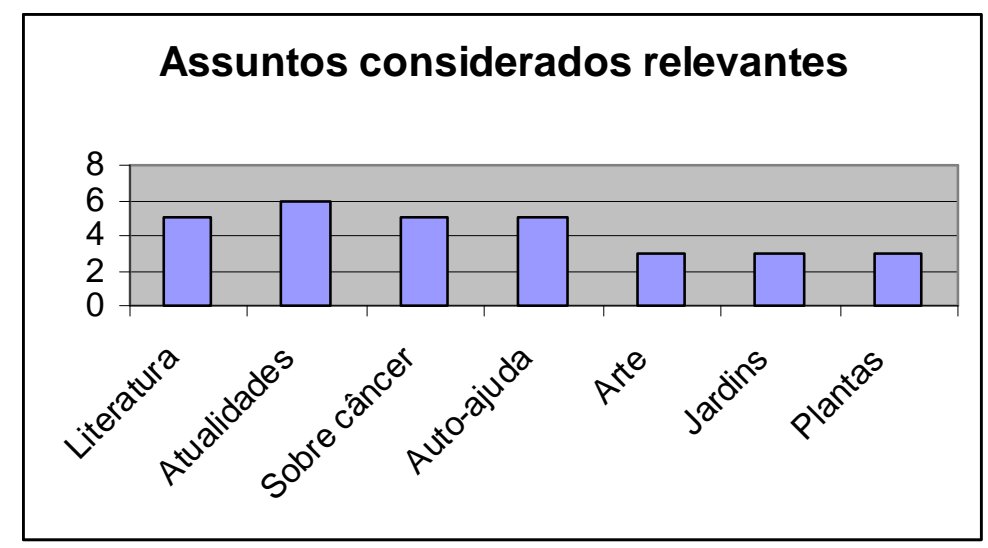

Figura 25 - Assuntos considerados importantes ter na Biblioteca da ABRAPEC pelos seus funcionários e voluntários

Além desses assuntos, foram citados, com menor freqüência: os direcionados para concursos (2), direcionados para vestibular (1), corte e costura (1), bordado (1), culinária (1), decoração (1), infantis (1) e técnicos (1).

Com relação à finalidade da utilização da Biblioteca da ABRAPEC, dentre as opções: aperfeiçoamento profissional; ocupação do tempo livre; pesquisas 
particulares; lazer e descanso; e motivação para o trabalho, a opção mais assinalada nos questionários foi o uso da biblioteca para o aperfeiçoamento profissional (5), seguida de pesquisas particulares (2), lazer e descanso (2), ocupar o tempo livre (1), motivação para o trabalho (1), conforme a Figura 26:

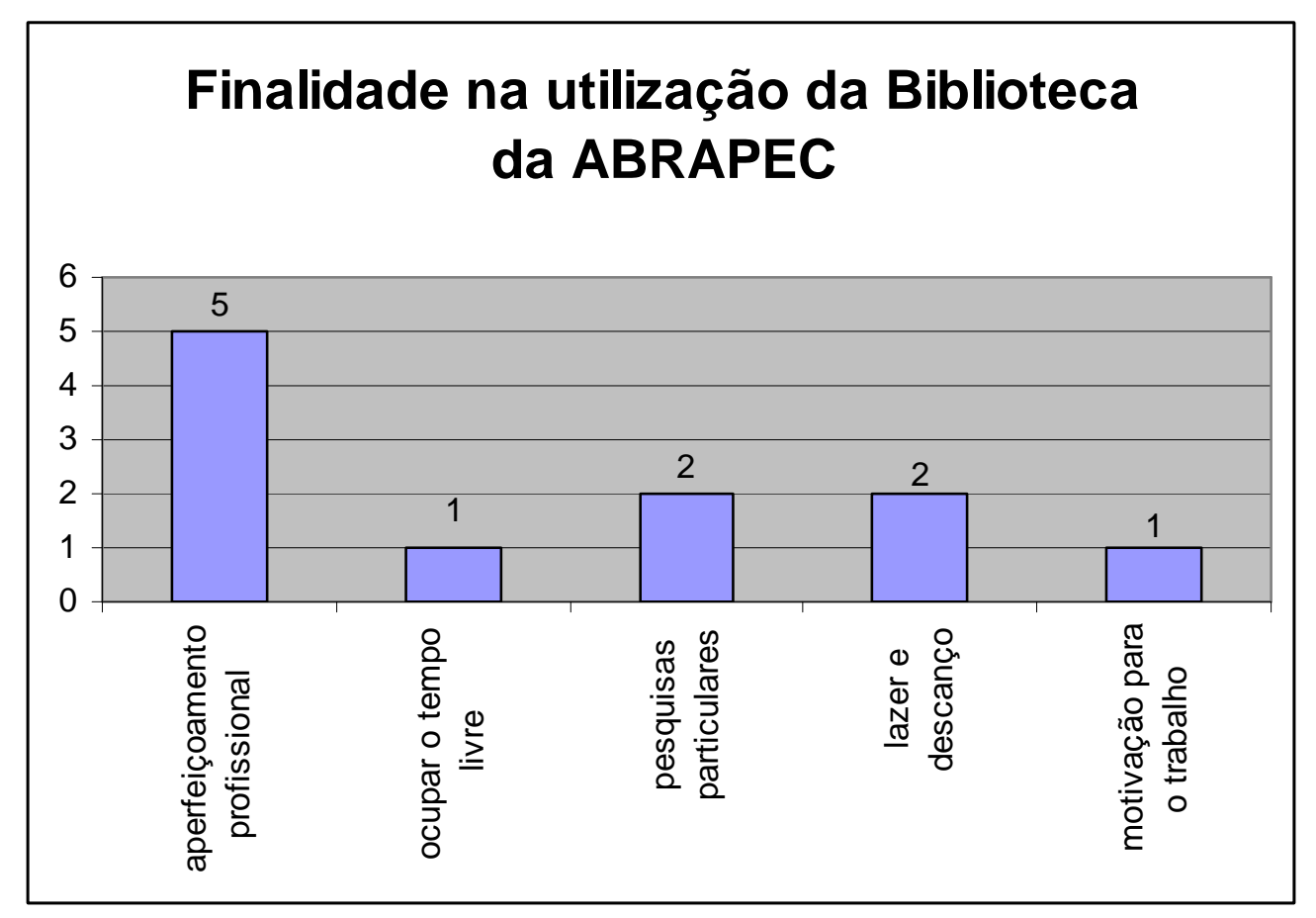

Figura 26 - Finalidade na utilização da Biblioteca da ABRAPEC

De acordo com a Figura 27, verifica-se que as respondentes julgam necessário que a biblioteca da ABRAPEC/DF disponibilize os serviços de empréstimo de livros (5); Informativos de novidades (4); Exposições (3); Acesso a Internet (2); Concursos Literários (1); e Contação de História (1). 


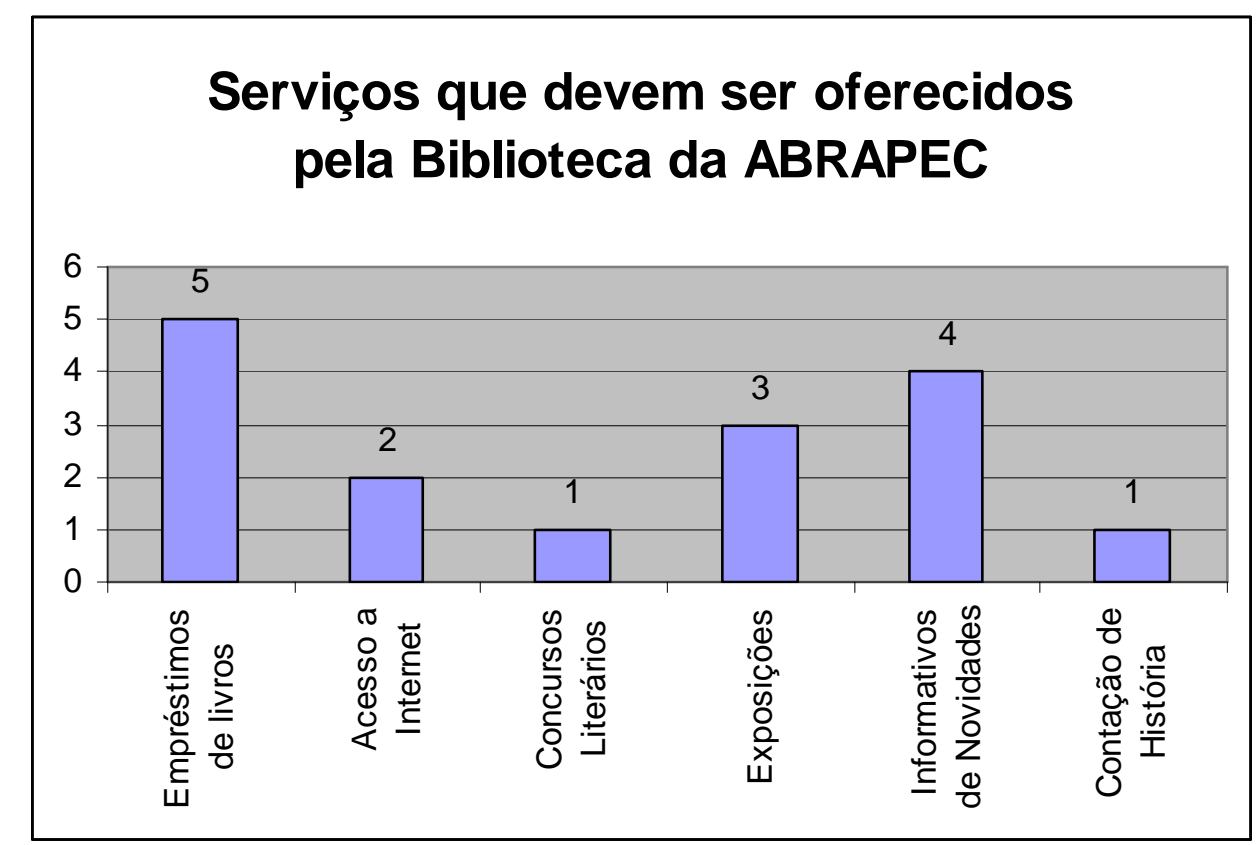

Figura 27 - Serviços que os funcionários e voluntários consideram importante a Biblioteca da ABRAPEC oferecer

Todas as funcionárias e voluntárias que responderam ao questionário consideram que a leitura traz algum tipo de beneficio para o ser humano. $O$ benefício mais citado foi o Enriquecimento Intelectual (7), seguido de Relaxamento (6), Motivação para o trabalho (6) e de Lazer (4), como demonstra a Figura 28.

Foram citados também como benefícios: o Discernimento, a Informação e a formação.

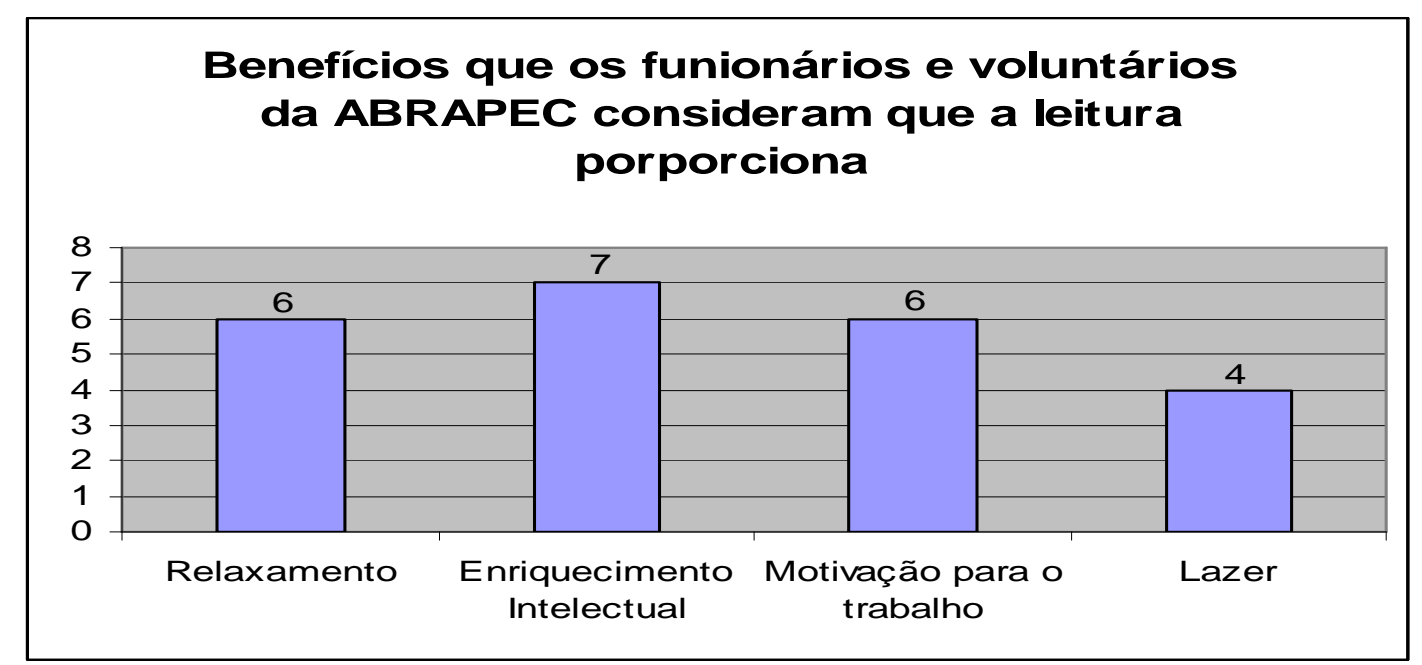

Figura 28 - Benefícios que os funcionários e voluntários da ABRAPEC consideram que a leitura proporciona 


\section{Sugestões para a reestruturação da Biblioteca da ABRAPEC}

Para a reestruturação da Biblioteca da ABRAPEC, os funcionários e voluntários julgam importantes que a unidade de informação ofereça os seguintes serviços e produtos:

- Disponibilizar um acervo de livros que contemple as diversas áreas do conhecimento;

- Divulgar o acervo, de modo que os pacientes se sintam motivados a ler;

- Oferecer diferentes atividades que incentivem a leitura, por meio da biblioteca da ABRAPEC/DF;

- Disponibilizar livros de literatura brasileira moderna;

- Proporcionar um ambiente adequado para as instalações da biblioteca, dentro das possibilidades da instituição;

- Disponibilizar um acervo com documentos sobre atualidades;

- Apresentar o resumo de algumas obras como forma de sugestão de leitura;

- Contar com a participação de estudantes de biblioteconomia para aprimoramento do funcionamento da biblioteca. 


\section{Projeto de reestruturação da Biblioteca da ABRAPEC- DF}

\subsection{Introdução}

A partir da revisão de literatura e do estudo de caso realizado, verificou-se a importância de uma biblioteca na ABRAPEC. Diante desta constatação sugere-se a reestruturação, da atual Biblioteca, de forma que ela possa suprir as necessidades informacionais dos pacientes e dos funcionários da Instituição, despertando neles maior interesse por atividades que envolvam a leitura e a informação.

A Biblioteca deverá ser a unidade de informação desta instituição, e, como tal, responsável por obter, organizar, manter e fornecer documentos e serviços de acordo com as necessidades dos funcionários e pacientes. Utilizará também a leitura como elemento terapêutico, buscando a melhoria dos pacientes, visando sempre seu bem estar.

Por se tratar de uma biblioteca que atenderá somente aos pacientes e funcionários da Associação, que possuem necessidades informacionais específicas, é considerada especializada. Entretanto, será considerada também uma biblioteca especial por se dedicar a um tipo especial de usuários, pacientes que possuem câncer e funcionários que trabalham diretamente com essa enfermidade. A partir da consideração de que se trata de uma biblioteca especial é possível propor produtos e serviços adequados a instituição e aos usuários da biblioteca, que deverão funcionar como uma forma de terapia, informação, cultura, e entretenimento para os pacientes da Instituição.

A reestruturação proposta inclui: a renovação e organização do acervo, a reorganização do espaço físico da biblioteca, a realização de atividades biblioterapêuticas, entre outros. 


\subsection{Objetivos:}

\section{Objetivo Geral:}

- Reestruturar a Biblioteca da ABRAPEC/DF e desenvolver atividades bibliotecárias e biblioterapêuticas com os pacientes

\section{Objetivos específicos:}

- Estudar o novo espaço físico destinado à Biblioteca da ABRAPEC-DF.

- Remanejar o acervo para este novo espaço.

- Criar um espaço para leitura e para uma videoteca.

- Estabelecer uma política de seleção, baseada nas informações obtidas por meio do estudo de usuários e da revisão de literatura sobre biblioterapia e sobre tipos de bibliotecas.

- Selecionar o acervo existente de acordo com a política estabelecida.

- Descartar e doar o material que não atende aos objetivos desta biblioteca.

- Solicitar doações de livros, periódicos e vídeos a outras instituições.

- Definir as normas e códigos que serão utilizados no processamento técnico do acervo.

- Catalogar, classificar e indexar o acervo.

- Informatizar o acervo para facilitar o acesso e a recuperação da informação.

- Preparar e organizar o acervo de acordo com as normas previamente estabelecidas, para armazenagem.

- Definir as normas e os procedimentos que serão utilizados na circulação de documentos (empréstimo, devolução e reserva).

- Atender as pesquisas dos funcionários e pacientes da instituição.

- Estabelecer um programa de atividades que contemplem a biblioterapia para atender aos pacientes.

- Estabelecer as atividades de incentivo à leitura e ao desenvolvimento das relações interpessoais entre os pacientes.

- Despertar o interesse dos pacientes da ABRAPEC pelas bibliotecas e atividades desenvolvidas. 


\subsection{Metas}

- Ampliar o espaço físico da Biblioteca da ABRAPEC/DF, em 20m².

- Remanejar e selecionar $100 \%$ do acervo existente.

- Criar um espaço para leitura com $10 \mathrm{~m}^{2}$.

- Estabelecer uma política de seleção dos documentos em 1 semana.

- Descartar e doar o material inservível em 3 semanas.

- Solicitar doações a 10 instituições.

- Definir as normas e códigos que serão utilizados no processamento técnico do acervo em 1 semana.

- Catalogar, classificar, indexar, informatizar e preparar 100\% do acervo.

- Elaborar o Manual de procedimentos, em 3 semanas.

- Atender a $100 \%$ da demanda dos funcionários e pacientes.

- Estabelecer o programa que contemple as atividades de biblioterapia e de incentivo a leitura, em 1 mês.

\subsection{Metodologia}

\subsubsection{Descrição}

A metodologia para o desenvolvimento deste projeto constará de 4 fases e 11 etapas, conforme descrição a seguir:

\section{○ Espaço físico}

A primeira fase é destinada à organização do espaço físico. Constará de uma única etapa referente à ampliação das instalações físicas da biblioteca.

Inicialmente será realizado um estudo de ampliação do espaço destinado a Biblioteca da ABRAPEC-DF, na sala de espera do atendimento psicológico e da massagem terapêutica. A escolha desse local se deve ao fato de que, enquanto os pacientes aguardam $\mathrm{O}$ atendimento a biblioteca poderá ser apresentada aos 
pacientes de forma que se inicie um trabalho de sensibilização e motivação para o seu uso. Em seguida será realizado o remanejamento do acervo, que atualmente encontra-se na recepção, para este novo espaço.

Nesse novo ambiente que abrigara a biblioteca será criado ainda um espaço reservado para a leitura e realização das atividades propostas.

\section{- Coleta de documentos}

A segunda fase consiste na coleta de documentos por meio da seleção, aquisição e descarte, etapas que a compreendem.

Tendo em vista que o acervo deverá atender as necessidades informacionais do público alvo da ABRAPEC-DF, pacientes e funcionários, será estabelecida uma política de seleção de documentos da Biblioteca da ABRAPEC-DF, com critérios previamente estabelecidos por bibliotecários voluntários, sendo que essa política deverá observar as necessidades e interesse demonstrado pelos usuários na pesquisa apresentada nesta monografia.

Em seguida o acervo que a Biblioteca possui será reavaliado, para que os documentos que não se enquadram nos critérios de seleção sejam doados para outras instituições. O acervo selecionado para permanecer na biblioteca passará por todo o processamento técnico necessário para sua posterior recuperação e só então, será feita uma lista de desiderata com os títulos e/ou assuntos que se deseja adquirir para complementar o acervo existente. Esses documentos serão então solicitados por meio de doações a Instituições parceiras e outras.

Assim como os livros que a ABRAPEC já possui, bem como as futuras aquisições deverão ser avaliadas a partir da política de seleção, de modo que o acervo contemple as áreas do conhecimento de interesse dos pacientes e funcionários da instituição.

De acordo com o interesse demonstrado pelos usuários na pesquisa realizada, o acervo terá documentos sobre atualidades, saúde, câncer, literatura, auto-ajuda, corte e costura, arte, jardim, plantas, entre outros. 


\section{- Processamento técnico}

A fase de processamento técnico dos documentos passará por diversas etapas que incluem a catalogação, a classificação, a indexação, a automação e a armazenagem desses documentos.

A catalogação será simplificada, conforme o primeiro nível de descrição, de acordo com as regras da Anglo-American Cataloguing Rules - AACR2.

A classificação dos documentos também será simplificada. Para isso utilizarse-á os 'grandes assuntos' da Classificação Decimal Universal - CDU, pois além do acervo ser pequeno, facilitará a busca de livros nas estantes pelos usuários, que com o passar do tempo, se tornarão independentes quanto a isso.

Os documentos serão indexados sem o auxilio de um tesauro ou vocabulário controlado, ou seja, utilizando-se a linguagem natural, pois isso facilitará a recuperação dos documentos pelos pacientes.

Para a automatização do acervo sugere-se a utilização de um software livre e gratuito, pois além de ser de simples compreensão e uso, não acarretará em nenhum tipo de ônus financeiro para a Associação. A automação irá facilitar o controle de empréstimo, bem como a organização e a recuperação dos documentos.

Após o processamento técnico, o acervo deverá ainda receber etiquetas e carimbos, de forma que facilite seu armazenamento e recuperação nas estantes bem como a identificação de que os documentos pertencem a esta biblioteca.

\section{- Atendimento aos usuários}

A fase de atendimento aos usuários terá como objetivo principal suprir as necessidades informacionais dos usuários da ABRAPEC-DF. As etapas a serem desenvolvidas constam do planejamento de como se dará: o empréstimo de documentos, as pesquisas solicitadas pelos usuários, as atividades biblioterapêuticas e as atividades que incentivem a leitura.

Para a realização de empréstimos e circulação de documentos em geral, serão definidas normas e procedimentos. Os usuários deverão inicialmente fazer um cadastro para poderem realizar o empréstimo domiciliar, que em principio será realizado no computador da recepção, onde será instalado um software para este e outros fins. Para realização dos empréstimos, reservas e devolução de documentos 
serão treinados dois funcionários da ABRAPEC, que terão acesso irrestrito ao modulo de circulação do software.

As pesquisas para os funcionários e pacientes serão realizadas de acordo com a demanda e deverão ser solicitadas por meio de um formulário. Tendo em vista que nem sempre haverá um bibliotecário disponível para realizá-las, de acordo com a urgência e especificidade que apresentar, a pesquisa poderá ser respondida preferencialmente por um dos bibliotecários voluntários, ou ainda por um dos funcionários que terão acesso ao módulo de pesquisa do sistema.

A Biblioteca atenderá os pacientes e funcionários da ABRAPEC-DF com 0 intuito de despertar neles o interesse por atividades que envolvam a leitura, suprindo ainda suas necessidades informacionais por meio do acesso a um acervo bibliográfico atualizado e diversificado, bem como, por meio da realização de atividades biblioterapêuticas e de incentivo a leitura, para os pacientes. As atividades serão desenvolvidas visando conscientizar esses usuários sobre a importância da leitura e para estimulá-los a ler, tanto como forma de terapia como para o enriquecimento intelectual.

Dentre os serviços e produtos que poderão ser oferecidos com o intuito de desenvolver o incentivo a leitura e a prática de atividades biblioterapêuticas no âmbito da instituição, destacam-se:

- Exposições de livros e periódicos novos que por algum motivo possam demonstrar serem atrativos para os usuários;

- Videoteca com filmes e documentários que os motivem de alguma forma no enfrentamento da enfermidade ou que podem suprir alguma necessidade de informação;

- Divulgação das sinopses de alguns livros, como sugestão de leitura, por meio de informativo - já existente na Associação - e por meio de um mostruário de livros;

- Criação de grupos de leitura para que os usuários possam interagir entre si e debater os temas principais dos livros lidos;

- Atividades de biblioterapia que deverão ser realizadas em parceria com os psicólogos da Instituição;

- Programação semanal de atividades que estimulem a leitura, como: teatro, roda de histórias, hora do conto, e outras. 
6.4.2 Cronograma

\begin{tabular}{|c|c|c|c|c|c|c|c|c|c|c|c|c|c|c|c|c|c|c|c|c|c|c|c|c|c|c|c|c|c|c|c|c|c|c|c|}
\hline $\begin{array}{c}\mathrm{N} \\
\underline{0}\end{array}$ & Fases & Etapa & Atividades & Mê & & & $2^{\circ} \mathrm{N}$ & Mês & & & Mê & & & & ${ }^{\circ} \mathrm{Me}$ & & & & $5^{\circ} \mathrm{N}$ & Mês & & & $6^{\circ} \mathrm{N}$ & Mês & & & & ${ }^{\circ}$ Mê & & & & $3^{\circ} \mathrm{Mé}$ & & & \\
\hline \multirow{3}{*}{1} & \multirow{3}{*}{$\begin{array}{l}\text { Espaço } \\
\text { Físico }\end{array}$} & \multirow{3}{*}{ Instalações } & $\begin{array}{c}\text { Estudo do novo } \\
\text { espaço }\end{array}$ & & & & & & & & & & & & & & & & & & & & & & & & & & & & & & & & \\
\hline & & & $\begin{array}{l}\text { Remanejamento do } \\
\text { acervo }\end{array}$ & & & & & & & & & & & & & & & & & & & & & & & & & & & & & & & & \\
\hline & & & $\begin{array}{l}\text { Criação de um espaço } \\
\text { para a leitura }\end{array}$ & & & - & & & & & & & & & & & & & & & & & & & & & & & & & & & & & \\
\hline \multirow{4}{*}{2} & \multirow{4}{*}{ Coleta } & \multirow{3}{*}{ Seleção } & $\begin{array}{l}\text { Estabelecimento da } \\
\text { política de seleção }\end{array}$ & & & & - & & & & & & & & & & & & & & & & & & & & & & & & & & & & \\
\hline & & & $\begin{array}{l}\text { Seleção do acervo } \\
\text { existente }\end{array}$ & & & & - & - & - & & & & & & & & & & & & & & & & & & & & & & & & & & \\
\hline & & & $\begin{array}{c}\text { Descarte e doação do } \\
\text { inservível }\end{array}$ & & & & & - & - & & & & & & & & & & & & & & & & & & & & & & & & & & \\
\hline & & Aquisição & $\begin{array}{l}\text { Solicitação das } \\
\text { doacões }\end{array}$ & & & & & & & & & & & & & & & & & & & & & & & & - & - & & - & & & & & \\
\hline \multirow{11}{*}{3} & \multirow{11}{*}{$\begin{array}{l}\text { Processos } \\
\text { técnicos }\end{array}$} & \multirow[t]{2}{*}{ Catalogação } & $\begin{array}{c}\text { Definição das normas } \\
\text { e códigos de } \\
\text { catalogação }\end{array}$ & & & & & & & - & & & & & & & & & & & & & & & & & & & & & & & & & \\
\hline & & & $\begin{array}{c}\text { Catalogação do } \\
\text { acervo }\end{array}$ & & & & & & & & - & - & - & - & - & - & - & - & - & - & - & - & - & - & & - & - & - & - & - & - & - & - & & - \\
\hline & & \multirow[t]{2}{*}{ Classificação } & $\begin{array}{c}\text { Definição das normas } \\
\text { e códigos de } \\
\text { classificação }\end{array}$ & & & & & & & - & & & & & & & & & & & & & & & & & & & & & & & & & \\
\hline & & & $\begin{array}{c}\text { Classificação do } \\
\text { acervo }\end{array}$ & & & & & & & & - & - & -1 & - & - & - & - & - & - & - & - & - & - & - & & - & - & - & - & - & - & - & - & . & - \\
\hline & & \multirow[t]{2}{*}{ Indexação } & $\begin{array}{l}\text { Definição das normas } \\
\text { de indexação }\end{array}$ & & & & & & & - & & & & & & & & & & & & & & & & & & & & & & & & & \\
\hline & & & Indexação do acervo & & & & & & & & - & - & - & - & - & - & - & - & - & - & - & - & - & - & . & - & - & - & - & - & - & - & - & & - \\
\hline & & \multirow{4}{*}{ Automação } & Definição do software & & & & & & & - & - & & & & & & & & & & & & & & & & & & & & & & & & \\
\hline & & & Definição do hardware & & & & & & & - & - & & & & & & & & & & & & & & & & & & & & & & & & \\
\hline & & & $\begin{array}{c}\text { Aquisição e instalação } \\
\text { do software e do } \\
\text { hardware }\end{array}$ & & & & & & & & - & - & - & & & & & & & & & & & & & & & & & & & & & & \\
\hline & & & $\begin{array}{c}\text { Informatização do } \\
\text { acervo }\end{array}$ & & & & & & & & - & - & - & - & - & - & - & - & - & - & - & - & - & - & - & - & - & - & - & - & - & - & - & & - \\
\hline & & $\begin{array}{l}\text { Armazena- } \\
\text { gem }\end{array}$ & $\begin{array}{c}\text { Preparação e } \\
\text { organização do acervo }\end{array}$ & & & & & & & & & - & - & - & - & - & - & - & - & - & - & - & - & - & r & - & - & - & - & - & - & - & - & & - \\
\hline
\end{tabular}




\begin{tabular}{|c|c|c|c|c|c|c|c|c|c|c|c|c|c|c|c|c|c|c|c|c|c|c|c|c|c|c|c|c|c|c|c|c|c|c|}
\hline \multirow{11}{*}{4} & \multirow{11}{*}{$\begin{array}{l}\text { Atendimen } \\
\text { to aos } \\
\text { usuários }\end{array}$} & \multirow[b]{2}{*}{$\begin{array}{l}\text { Circulação de } \\
\text { materiais }\end{array}$} & Definição de normas & & & & & & & & - & & & & & & & & & & & & & & & & & & & & & & & \\
\hline & & & $\begin{array}{l}\text { Estruturação dos } \\
\text { procedimentos }\end{array}$ & & & & & & & & & - & - & - & - & - & - & - & - & . & - & - & - & - & - & - & - & - & - & - & - & - & - & - \\
\hline & & \multirow{2}{*}{$\begin{array}{l}\text { Pesquisa/ } \\
\text { Referência }\end{array}$} & $\begin{array}{l}\text { Atendimento as } \\
\text { pesquisas dos } \\
\text { funcionários }\end{array}$ & & & & & & & & - & - & - & - & - & - & - & - & - & 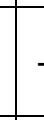 & - & - & - & - & - & - & - & - & - & - & - & - & - & - \\
\hline & & & $\begin{array}{c}\text { Atendimento as } \\
\text { demandas dos } \\
\text { pacientes }\end{array}$ & & & & & & & & - & - & - & - & - & - & - & - & - & - & 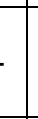 & - & - & - & - & - & - & - & - & - & - & - & - & - \\
\hline & & \multirow{7}{*}{$\begin{array}{l}\text { Biblioterapia e } \\
\text { atividades de } \\
\text { Incentivo à } \\
\text { leitura }\end{array}$} & Grupos de leitura & & & & & & & & - & - & - & - & - & - & - & - & - & - & 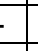 & - & - & \begin{tabular}{|l|}
- \\
\end{tabular} & - & - & - & - & - & - & - & - & - & - \\
\hline & & & Roda de histórias & & & & & & & & - & - & - & - & - & - & - & - & - & - & - & - & - & - & - & - & - & - & - & - & - & - & - & - \\
\hline & & & Hora do conto & & & & & & & & - & - & - & - & - & - & - & - & - & - & 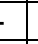 & - & - & - & - & - & - & - & - & - & - & - & - & - \\
\hline & & & Teatro & & & & & & & & - & - & - & - & - & - & - & - & - & - & 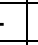 & - & - & - & - & - & - & - & - & - & - & - & - & - \\
\hline & & & $\begin{array}{l}\text { Exposições de livros e } \\
\text { periódicos novos }\end{array}$ & & & & & & & & -1 & -1 & - & - & - & - & - & - & - & 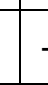 & 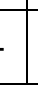 & - & - & - & - & - & - & - & - & - & - & - & - & - \\
\hline & & & $\begin{array}{c}\text { Divulgação das } \\
\text { sinopses de alguns } \\
\text { livros, como sugestão } \\
\text { de leitura }\end{array}$ & & & & & & & & - & - & - & - & - & - & - & - & - & 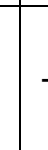 & - & - & - & - & - & - & - & - & - & - & - & - & - & - \\
\hline & & & $\begin{array}{l}\text { Videoteca com filmes } \\
\text { e documentários }\end{array}$ & & & & & & & & - & - & - & - & - & - & - & - & - & 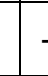 & 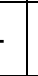 & - & - & - & - & - & - & - & - & - & - & - & - & - \\
\hline
\end{tabular}




\subsection{Recursos necessários}

Para a viabilização deste projeto serão necessários os seguintes recursos:

\section{- Recursos humanos}

A biblioteca contará, inicialmente, com a ajuda de duas bibliotecárias voluntárias, que a reestruturarão, o que inclui além da organização do espaço físico, a coleta de materiais, o processamento técnico dos livros, e o atendimento de usuários. Como será um serviço voluntário, ou seja, as bibliotecárias não estarão todos os dias na Instituição, elas treinarão dois funcionários contratados da ABRAPEC-DF que poderão colaborar na realização de pesquisas e na realização de empréstimos.

A prática biblioterapêutica e de incentivo a leitura contará com a participação de bibliotecários voluntários, e também das psicólogas que trabalham na ABRAPECDF, podendo ainda contar com a participação de um paciente da Instituição, que seja alfabetizado e tenha condições de desenvolver atividades de leitura com os demais pacientes.

\section{- Recursos informacionais}

O acervo da biblioteca deverá estar disponível tanto por meio de livros, bem como, de revistas, fitas VHS e DVDs. Conforme dito anteriormente, esse material será adquirido por meio de doações de instituições parceiras.

\section{○ Recursos Materiais:}

A biblioteca deverá contar com mobiliário especifico que inclui:

- Duas estantes próprias para a organização do acervo, sendo que a Instituição já possui uma, e a outra deverá ser adquirida por meio de doação;

- Um mostruário de livros, também adquirido por meio de doação;

- Dois sofás e 3 poltronas, que a instituição já possui e utiliza na sala de espera; 
- Um computador, para consulta do acervo e empréstimos domiciliares. Em princípio será utilizado o que fica na recepção da instituição.

- Um aparelho de DVD e uma televisão para realização de atividades com o pacientes, sendo que ABRAPEC já dispõe.

\section{- Recursos técnicos}

Os recursos técnicos necessários para o processamento dos documentos são a AACR-2 e a CDU. Inicialmente a AACR-2 que será utilizada poderá ser obtida por meio de doação, ou ainda, com uma das bibliotecárias voluntárias. A CDU, tendo em vista seu alto custo e o fato de que o acervo será organizado em "grandes assuntos", não será adquirida. Em princípio utilizar-se-á uma tabela que contém as principais classes da CDU e que pode ser facilmente obtida na internet.

\section{○ Recursos tecnológicos}

Para o processamento técnico do acervo e circulação dos documentos a biblioteca contará com um software livre e gratuito que poderá ser encontrado na internet.

Devido à falta de recursos, em princípio o computador da recepção será utilizado tanto para a circulação dos documentos, quanto para o processamento técnico deles. Posteriormente, a instituição deverá adquirir por meio de doação um computador que possa ficar na sala da biblioteca a ser utilizado como seu instrumento básico.

As impressoras e telefones serão os existentes em outros setores da instituição, disponibilizados também, para uso da biblioteca.

\section{○ Recursos financeiros}

O estudo de caso permitiu notar que quase todas as atividades desenvolvidas na Instituição dependem do serviço de voluntários e de doações. Nas atividades a serem desenvolvidas na biblioteca, inicialmente, não será diferente.

Tendo em vista que a Biblioteca da ABRAPEC-DF não conta com recursos financeiros próprios, as doações e o serviço voluntário, juntamente com o auxílio dos profissionais da ABRAPEC, serão a única forma para a viabilização desse projeto. 


\section{Considerações finais}

A Associação Brasileira de Assistência as Pessoas com Câncer - ABRAPEC é uma organização não-governamental que atende pessoas portadoras de câncer que não possuem condições de arcar com as despesas do tratamento e se encontram vulneráveis devido à enfermidade que os acomete. Por meio dos serviços oferecidos a instituição busca, além de elevar a auto-estima dos pacientes, realizar atividades que tornem o tratamento menos doloroso. A biblioteca é um dos serviços oferecidos, que ao disponibilizar livros procura despertar nos pacientes o interesse pela leitura bem como pela alfabetização, tendo em vista que muitos deles possuem baixo grau de instrução.

A partir da revisão de literatura, estudo de caso e dos questionários aplicados aos pacientes e funcionários da ONG foi possível conhecer a realidade da instituição e suas reais necessidades quanto à reestruturação da biblioteca e a realização de atividades que envolvam a biblioterapia no tratamento dos enfermos.

A revisão de literatura sobre biblioterapia, o processo de planejamento e os tipos de bibliotecas fornece subsídios suficientes para que o estudo se realizasse de acordo com os princípios estabelecidos. A primeira permitiu a compreensão dos benefícios que a utilização dos livros e da leitura pode trazer para pessoas que se encontram vulneráveis devido à doença; a segunda forneceu informações suficientes para que se compreendesse a importância de se planejar previamente a reestruturação da biblioteca bem como a realização das atividades; e a última, por apresentar as peculiaridades dos diversos tipos de bibliotecas existentes, permitiu que se chegasse a conclusão, juntamente com a análise das características da ABRAPEC, de que a biblioteca deve possuir as características de uma biblioteca especial, e portanto deve dar apoio informacional aos pacientes e seus familiares de forma que além de se manterem devidamente atualizados sobre as novidades da doença que os acomete, eles possam utilizar a biblioteca como apoio educacional e como forma de entretenimento.

O estudo de caso revelou o contexto no qual a ABRAPEC/DF está inserida, de forma que tornou possível a compreensão de sua estrutura organizacional, o conhecimento de sua missão e de seus principais objetivos quanto ao atendimento dos pacientes que freqüentam a unidade regularmente. Tendo em mente o objetivo 
principal desta monografia, ele demonstrou ainda, juntamente com a análise do perfil dos usuários, a necessidade e interesse dos mesmos na reestruturação da biblioteca e na realização de atividades que os motivem e incentivem a estudar e ler com uma maior freqüência. A pesquisa realizada com os pacientes revelou ainda, que apesar de muitos possuírem baixo nível de instrução, e de não freqüentarem bibliotecas atualmente, eles apóiam a reestruturação da biblioteca para que uma maior variedade de material bibliográfico seja disponibilizado de forma que além de atender aos pacientes do projeto Educação de Jovens e Adultos, desperte nos outros o interesse nas atividades que serão oferecidas.

O sucesso da biblioteca e das atividades que serão oferecidas dependerão, inicialmente, da ajuda de voluntários conhecedores das atividades biblioteconômicas, que poderão futuramente ser profissionais contratados, pois são eles que tornarão a reestruturação da biblioteca uma realidade na instituição, de forma que não seja apenas uma novidade que aos poucos será esquecida ou abandonada.

Dentro deste contexto, onde a informação se torna subsídio fundamental tanto para o desenvolvimento das organizações, quanto para o desenvolvimento do ser humano, e onde todo o cidadão, ainda que se encontre em situação de risco, necessita estar informado, se bem planejada, a reestruturação da biblioteca além de funcionar como apoio pessoal aos que se encontram em situações vulneráveis, permitirá, que os pacientes tenham acesso a informações relevantes, tanto para o enriquecimento intelectual quanto para a melhoria de sua qualidade de vida. 


\section{Referências}

ALMEIDA, Maria Christina Barbosa de. Planejamento de bibliotecas e serviços de informação. 2. ed., rev. e ampl. Brasília: Briquet de Lemos/Livros, 2005. 144 p. ISBN 8585637277

ALVES, Maria Helena Hess. A aplicação da biblioterapia no processo de reintegração social. Revista Brasileira de Biblioteconomia e Documentação, São Paulo, v.15, n.1/2 p.54-61, jan./jun. 1982.

ANDRADE, Rosane Maria Nunes. Bibliotecas: lugar de memória e de preservação o caso da biblioteca Nacional do Brasil. Patrimônio e memória: Revista Eletrônica do CEDAP, v.4, n.2, p. 1-18 - jun. 2009. Disponível em: <http://www.assis.unesp.br/cedap/patrimonio_e_memoria/patrimonio_e_memoria_v4 .n2/artigos/bibliotecas.pdf> Acesso em: 05 out. 2009.

ARAÚJO, Audinêz Barreto; SILVA, lara Celly Gomes da; ANDRADE, Magnólia de CARVALHO. Formação e desenvolvimento de coleções em uma biblioteca especializada. In: Seminário de pesquisa do centro de ciências sociais aplicadas, 2004, Natal. Seminário de pesquisa do centro de ciências sociais aplicadas, 2004. v. 10.Disponível em: <http://201.2.114.147/bds/bds.nsf/1bf9a95042a2f10a03256f1d004 ed47e /\$file /nt0009d02e.pdf >; Acesso em: 15 ago. 2009.

ASSOCIAÇÃO BRASILEIRA DE ASSISTÊNCIA AS PESSOAS COM CÂNCER. Estatuto. São Paulo, 2009. 13 p.

ASSOCIAÇÃO BRASILEIRA DE NORMAS TÉCNICAS. NBR 6023: informação e documentação: referência: elaboração. Rio de Janeiro, 2002.

NBR 6024: informação e documentação: numeração progressiva das seções de um docmento: apresentação. Rio de Janeiro, 2003.

NBR 6028: informação e documentação: resumo: apresentação. Rio de Janeiro, 2003.

NBR 10520: informação e documentação: citações em documentos: apresentação. Rio de Janeiro, 2002.

NBR 14724: informação e documentação: trabalhos acadêmicos: apresentação. Rio de Janeiro, 2006. 
BORGES, Maria Alice Guimarães. A compreensão da sociedade da informação. Ciência da informação, Brasília, v. 29, n. 3, p. 25-32, set./dez. 2000. Disponível em: < http://revista.ibict.br/ciinf/index.php/ciinf/article/view/214/189>. Acesso em: 28 nov. 2009.

BORGES, Mônica Erichsen Nassif. A informação como recurso gerencial das organizações na sociedade do conhecimento. Ciência da informação, Brasília, v. 24, n. 2, 15 p. 1995. Disponível em: < http://revista.ibict.br/ciinf/index.php/ciinf/article /view/551/500>. Acesso em: 28 nov. 2009.

BORN, Roger. Construindo o plano estratégico: casos reais e dicas práticas. Sulina: 2007.

BRASIL. FUNDAÇÃO BIBLIOTECA NACIONAL. A biblioteca pública: administração, organização, serviços. Porto alegre: L \&PM, 1999.118 p.

CALDIN, Clarice F. A leitura como função terapêutica: biblioterapia. Encontros Bibli, Florianópolis, n.12, p. 32-44, dez.2001 .Disponível em :

<http://www.ced.ufsc.br/bibliote/encontro/ bibli12/caldin.html>. Acesso em: 19 maio 2009.

Biblioterapia: atividades de leitura desenvolvidas por acadêmicos do Curso de Biblioteconomia da Universidade Federal de Santa Catarina. Biblios: Revista Eletrônica de Bibliotecologia y Ciências de la Información, Lima, año 6, n. 21/22, p.13-25, Ene./Ago. 2005. Disponível em <http://redalyc.uaemex.mx/redalyc /pdf/161/16102202.pdf > Acesso em: 19 maio 2009.

CERDEIRA, Theodolindo. A biblioteca escolar no planejamento educacional. Revista de Biblioteconomia de Brasília, Brasília, v. 5, n. 1, p. 35 - 43, jan./ jun. 1977.

CHIAVENATO, Idalberto. Introdução geral da administração. 6. ed. rev. e atual. Rio de janeiro: Elsevier, 2000. 700 p. ISBN 8535205578.

DICIONÁRIO do Aurélio. Disponível em: <http://www.dicionariodoaurelio. com/ dicionario.php?P=Projecao>. Acesso em: 18 maio 2009.

DICIONÁRIO médico. Disponível em <http://www.dicionáriomédico.com >. Acesso em: 21 maio 2009. 
DICIONÁRIO Michaelis. Disponível em: http://michaelis.uol.com.br/ moderno /portugues/index.php?lingua=portuguesportugues\&palavra=biblioterapia. Acesso em: 20 maio 2009.

DOMINGO, Marta Torres Santo. La función social de las bibliotecas universitárias. Boletín de la Asociación Andaluza de Bibliotecarios, no 80, Septiembre 2005, p. 43-70.

FERREIRA, Danielle Thiago. Biblioterapia: uma prática para o desenvolvimento pessoal. Educação Temática Digital, São Paulo, v.4, n.2, p.35-47, jun. 2003. Disponível em: <http://www.fae.unicamp.br/etd/viewarticle.php?id=272\&locale=en> Acesso em: 16 abr. 2009.

FERREIRA, Lusimar Silva. Bibliotecas universitárias brasileiras: análise de estruturas centralizadas e descentralizadas. São Paulo: Pioneira, 1980.

FRAGOSO, Graça Maria. Biblioteca na escola. Revista ACB Biblioteconomia em Santa Catarina, Florianópolis, v. 7, n. 1, p. 124-131, jan./dez, 2002. Disponível em: < http://geocities.yahoo.com.br/gra_fragoso/textos/bib_escola.html>. Acesso em: 12 ago. 2009.

HILLESHEIM, A. I. A.; FACHIN, G. R. Bories. Biblioteca escolar e a leitura. Revista ACB (Florianópolis), Florianópolis, v. 8/9, p. 35-45, 2004.

JONES, Gareth R.; GEORGE, Jennifer M. George. Administração contemporânea. 4. ed. 2008.

LASTRES, Helena M. M. Informação e conhecimento na nova ordem mundial. Ciência da informação, Brasília, v. 28, n. 3, 7 p. 1999 Disponível em: < http://revista.ibict.br/ciinf/index.php/ciinf/article/view/214/189>. Acesso em: 28 nov. 2009.

LOUSADA, Alexandre; ALVEIRINHO, Ana. Bibliotecas especiais: para uma igualdade de acesso. Lisboa, 2006.

LUCK, Esther Hermes; Souza, Clarice M. de Souza et al. A Biblioteca Universitária e as Diretrizes Curriculares do Ensino de Graduação. XI SNBU 2000, Anais. Florianópolis, abril/2000. 
MACIEL, Alba Costa. Planejamento de bibliotecas: o diagnóstico. Niterói, RJ: Editora da Universidade Federal Fluminense, 1993. 91 p. : ISBN 85-228-0121-5

MANAGAZ, Ronaldo; ALVES, M. A. M.. Depósito Legal: esperança ou realidade. Revista de Biblioteconomia de Brasília, v.1, n. 35, p. 35-44, jan/jun. 1987. Disponível em: <http://164.41.122.25/portalnesp/ojs-2.1.1/index.php/RBB/article /view/428/398> Acesso em: 05 out. 2009.

MILOMEM, Valmir Nascimento. A didática do humor. Blog [internet]. Disponível em <http://comoviveremos.com/2006/08/11/a-didatica-do-humor/ > Acesso em: 29 maio 2009.

MIRANDA, Ana Cláudia Carvalho de. Formação e desenvolvimento de coleções em bibliotecas especializadas. Informação \& Sociedade, João Pessoa, v. 17, n. 1, p. 87-94, jan./abr., 2007.

MONTE-MÓR, Jannice. Reforma da Biblioteca Nacional. Ciência da Informação, Rio de Janeiro, v. 1, n. 1, p. 15-23, 1972. Disponível em : <http://revista.ibict.br/ index .php/ciinf/article/view/1652/1260> acesso em : 05 out. 2009.

MONTET, Pierre. O Egito no tempo de Ramsés. São Paulo: companhia das letras: circulo do livro, 1989. 367 p.

OLIVEIRA, Cristina da Cruz de; BOTELLO, Rafael Guimarães; FARIA JUNIOR, Alfredo. Uso da biblioteca universitária: um guia para alunos de educação física. Revista Digital, Buenos Aires, v. 12, n. 116, jan. 2008. Disponível em: < http://www.efdeportes.com/efd116/uso-da-biblioteca-universitaria.htm >. Acesso em: 7 out. 2009.

OLIVEIRA, Djalma de Pinho Rebouças de. Planejamento estratégico: conceitos, metodologia e práticas. 24. ed. São Paulo: Atlas, 2007.

OUAKNIN, Marc Alain. Biblioterapia. São Paulo: Loyola, 1996. 341 p. Disponível em: <http://books.google.com.br/books?id=sdDJpKEPetsC\&printsec=frontcover\&d q=ouaknin+biblioterapia\#PPA27,M1 > Acesso em: 16 abr. 2009.

PEREIRA, Marília Mesquita Guedes. A biblioterapia e leitura critica para a formação da cidadania com os alunos do instituto dos cegos da paraíba "adalgisa cunha". 15 p. Disponível em: <http://dici.ibict.br/archive/00000779 101/T128.pdf >. Acesso em: 16 abr. 2009. 
PINTO, Célia Regina Jardim. As ONGs e a política no Brasil: presença de novos atores. Revista de Ciências Sociais, Rio de Janeiro, v. 49, n. 3, p. 651-613, 2006.

PINTO, Virginia Bentes. A biblioterapia como campo de atuação para o bibliotecário. TransInformação, Campinas, v.17, n.1, p. 31-43, jan./abr., 2005. Disponível em: $<$ http://revistas.puc-campinas.edu.br/transinfo/viewarticle. php?id=79\&locale=en $>$. Acesso em: 21 abr. 2009.

ROSA, Aparecida Luciene Resende. As cartas de Ana Cristina César: uma contribuição para a biblioterapia. Dissertação apresentada à Universidade do Vale do Rio Verde UNINCOR. Minas Gerais, 2006. Disponível em: <http://www.unincor.br/pos/cursos/MestreLetras/arquivos/dissertacoes/APARECIDA \%20LUCIENE\%20RESENDE\%20ROSA.pdf> Acesso em 20 abr. 2009.

SALASÁRIO, Maria Guilhermina da Cunha. Biblioteca especializada e informação: da teoria conceitual á prática na biblioteca do laboratório de mecânica de precisão LMP/UFSC. Revista ACB: Biblioteconomia em Santa Catarina, Florianópolis, v. 5, n. 5, p. 104-119, jan. 2000.

SEITZ, Eva M. Biblioterapia: uma experiência com pacientes internados em clinica médica. Campinas, v.1, n.1, p. 73-85, dez. 2005. Disponível em: <http://dici.ibict.br/archive/00000919/01/ETD-2005-52\%5B1\%5D.pdf> Acesso em: 19 abr. 2009.

SILVA, Alexandre Magno da. Características da produção documental sobre biblioterapia no Brasil. Florianópolis: [s.n.], 2005. 121 f. Dissertação (Mestrado em Psicologia) - Universidade Federal de Santa Catarina, Disponível em: <http://www.tede.ufsc.br/teses/PPSI0170.pdf > Acesso em 30 maio 2009.

SUAIDEN, Emir José. A biblioteca pública no contexto da sociedade da informação. Ciência da Informação, Brasília, v. 29, n. 2, p. 52-60, maio/ago. 2000. Disponível em: < http://www.scielo.br/pdf/ci/v29n2/a07v29n2.pdf > Acesso em 10 out 2009.

TENÓRIO, Fernando G. (org.). Gestão de ONGs: principais funções gerenciais. 9. ed. Rio de Janeiro: Editora FGV, 2005. 


\section{ANEXOS:}

ANEXO A - Questionário aplicado aos pacientes da ABRAPEC

Universidade de Brasília - UnB

Faculdade de Economia, Administração, Contabilidade, Ciência da Informação e Documentação - FACE

Departamento de Ciência da Informação e Documentação - CID

\section{Questionário - Pacientes}

1. Sexo
( ) Feminino
( ) Masculino

2. Em que faixa etária você se encontra?
( ) De 11 a 20
( ) de 21 a 30
( ) de 41 a 50
( ) de 31 a 40
( ) Mais de 50

3. Há quanto tempo você freqüenta a ABRAPEC?
( ) Menos de 6 meses
( ) De 6 meses a 1 ano
( ) Mais de um ano

4. Com que freqüência você vem a ABRAPEC?
( ) Esta é a primeira vez
( ) Uma vez por semana
( ) Duas vezes ao mês
( ) Duas vezes ou mais por semana
( ) Uma vez ao mês

5. Qual a sua profissão?

6. Qual o seu nível de instrução?
( ) Não sei ler
( ) Ensino fundamental incompleto
( ) Ensino fundamental completo
( ) Ensino médio incompleto 
( ) Ensino médio completo

( ) Superior completo

( ) Superior incompleto

7. Gosta de ler?
( ) Sim
( ) Não

8. Com que freqüência você costuma ler?
( ) Diariamente
( ) Mensalmente
( ) Semanalmente
( ) Somente quando é algo que interessa

9. Sobre qual (is) assunto (s) você gosta de ler?
( ) Literatura
( ) Atualidades
( ) Sobre câncer
( ) Corte e costura
( ) Bordado
( ) Culinária
( ) Auto-ajuda
( ) Arte
( ) Livros didáticos
( ) Saúde
( ) Esporte

( ) Jardins

( ) Plantas

( ) Decoração

( ) Novelas

( ) Sobre artistas

( ) Carro

( ) Música

( ) Direcionados para concursos e/ou vestibular

( ) Outros:

10. O que você acha de ter uma biblioteca na ABRAPEC?
( ) Ótimo, eu freqüentaria
( ) Ótimo, mas não freqüentaria
( ) Bom, mas não freqüentaria
( ) Bom, eu freqüentaria
( ) Acho desnecessário
( ) Não acho nada

11. Você utiliza os livros que a ABRAPEC possui?
( ) Sim
( ) Não. Por quê?

12. Você gostaria que a biblioteca da ABRAPEC tivesse revistas e/ou jornais?
( ) Sim
( ) Não 
13. Qual (is) assunto (s) você considera importante e/ou gostaria de encontrar no acervo da Biblioteca da ABRAPEC?
( ) Literatura
( ) Atualidades
( ) Sobre câncer
( ) Corte e costura
( ) Bordado
( ) Culinária
( ) Auto-ajuda
( ) Arte
( ) Livros didáticos
( ) Saúde
( ) Esporte

( ) Jardins

( ) Plantas

( ) Decoração

( ) Novelas

( ) Sobre artistas

( ) Carro

( ) Música

( ) Direcionados para concursos e/ou vestibular

( ) Outros:

14. Você acha que a leitura traz algum tipo de beneficio para o ser humano?
( ) Sim.
( ) Não. Por quê?

15. Qual (is) benefício (s) você acha que a leitura pode trazer?
( ) Relaxamento
( ) Enriquecimento intelectual
( ) Motivação para o trabalho
( ) Lazer
( ) outros

16. Qual o seu objetivo quando vai a uma biblioteca?
( ) Nunca vou a uma biblioteca
( ) Fazer pesquisas
( ) Ler livros
( ) Ler revistas e jornais
( ) Consultar dicionários, enciclopédias etc

( ) Pegar livros emprestados

( ) Acessar a internet

( ) Ocupar o tempo livre

( ) Estudar

( ) Outros:

17. Sugestões para a Biblioteca a ser criada na ABRAPEC: 
ANEXO B - Questionário aplicado aos Funcionários da ABRAPEC

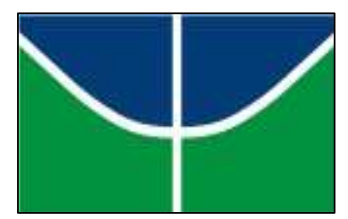

Universidade de Brasília - UnB

Faculdade de Economia, Administração, Contabilidade, Ciência da Informação e Documentação - FACE

Departamento de Ciência da Informação e Documentação - CID

\section{Questionário - Funcionários}

№:

Prezado funcionário,

Este questionário constitui um instrumento de coleta de dados para um trabalho de conclusão do curso de Biblioteconomia da Universidade de Brasília. Seu principal objetivo é descobrir o interesse pela leitura demonstrado pelos pacientes da ABRAPEC. Desde já muito obrigada pela sua colaboração.

1. Sexo:
( ) Feminino
( ) Masculino

2. Em que faixa etária você se encontra?
( ) De 11 a 20
( ) de 41 a 50
( ) de 21 a 30
( ) Mais de 50
( ) de 31 a 40

3. Qual sua função na ABRAPEC?
( ) Gerente operacional
( ) Motorista
( ) Assistente social
( ) Psicóloga
( ) Auxiliar de escritório
( ) Voluntário:
( ) Recepcionista
( ) Outro:

4. Qual seu nível de instrução?
( ) Ensino fundamental incompleto
( ) Ensino Superior incompleto
( ) Ensino fundamental completo
( ) Ensino superior. Curso:
( ) Ensino médio
( ) Pós-graduação

5. Você utiliza os livros que a ABRAPEC possui?
( ) Sim.
( ) Não. Por quê? 
6. Considera importante a existência de uma biblioteca na ABRAPEC?

( ) Sim. Por quê?

( ) Não. Por quê?

7. Qual (is) assunto (s) você considera importante e/ou gostaria de encontrar no acervo da Biblioteca da ABRAPEC?
( ) Literatura
( ) Atualidades
( ) Sobre câncer
( ) Corte e costura
( ) Bordado
( ) Culinária
( ) Auto-ajuda
( ) Arte

( ) Jardins

( ) Plantas

( ) Decoração

( ) Novelas

( ) Sobre artistas

( ) Direcionados para concurso

( ) Direcionados para o vestibular

( ) Outros:

8. Você utilizaria a Biblioteca da ABRAPEC para:
( ) Aperfeiçoamento profissional
( ) Lazer/Descanso
( ) Ocupar o tempo livre
( ) Motivação para o trabalho
( ) Pesquisas particulares
( ) Não utilizaria
( ) Outros:

9. Qual (is) o(s) serviço(s) você acha que a Biblioteca deve oferecer?
( ) Empréstimo de livros
( ) Acesso a Internet
( ) Concursos literários
( ) Exposições
( ) Informativo de novidades
( ) Outros:

10. Você acha que a leitura traz algum tipo de beneficio para o ser humano?
( ) $\operatorname{Sim}$
( ) Não

11. Quais benefícios você acha que a leitura pode trazer?
( ) Relaxamento
( ) Enriquecimento intelectual
( ) Motivação para o trabalho
( ) Lazer
( ) Outros:

12.Sugestões para a Biblioteca a ser criada na ABRAPEC: 
